UNIVERSIDADE DE SÃO PAULO

FACULDADE DE ECONOMIA, ADMINISTRAÇÃO E CONTABILIDADE DEPARTAMENTO DE ECONOMIA PROGRAMA DE PÓS-GRADUAÇÃO EM TEORIA ECONÔMICA

SOBRE A CONTRUÇÃO DA POLÍTICA ECONÔMICA:

UMA DISCUSSÃO DOS DETERMINANTES DA TAXA REAL DE JUROS NO BRASIL

Emilio Chernavsky

Orientadora: Prof ${ }^{\mathrm{a}}$.Dr ${ }^{\mathrm{a}}$.Leda Maria Paulani

SÃO PAULO 
Prof $^{\mathrm{a}}$.Dr ${ }^{\mathrm{a}}$. Suely Vilela

Reitor da Universidade de São Paulo

Prof.Dr.Carlos Roberto Azzoni

Diretor da Faculdade de Economia, Administração e Contabilidade

Prof.Dr.Joaquim José Martins Guilhoto

Chefe do Departamento de Economia

Prof.Dr.Dante Mendes Aldrighi

Coordenador do Programa de Pós-Graduação em Economia 
SOBRE A CONTRUÇÃO DA POLÍTICA ECONÔMICA:

UMA DISCUSSÃO DOS DETERMINANTES DA TAXA REAL DE JUROS NO

BRASIL

Dissertação apresentada ao Departamento de Economia da Faculdade de Economia, Administração e Contabilidade da Universidade de São Paulo como requisito para a obtenção do título de Mestre em Economia

Orientadora: Prof $^{\mathrm{a}}$.Dr ${ }^{\mathrm{a}}$.Leda Maria Paulani

SÃo PAULO 
Dissertação defendida e aprovada no Departamento de Economia da Faculdade de Economia, Administração e Contabilidade da Universidade de São Paulo - Programa de Pós-Graduação em Economia, pela seguinte banca examinadora:

\section{Chernavsky, Emilio}

Sobre a construção da política econômica: uma discussão dos determinantes da taxa real de juros no Brasil / Emilio Chernavsky. - São Paulo, 2007.

$113 \mathrm{p}$.

Dissertação (Mestrado) - Universidade de São Paulo, 2007 Bibliografia.

1. Taxa de juros 2. Política monetária I. Universidade de São Paulo. Faculdade de Economia, Administração e Contabilidade II. Título. 
A Débora

Pela companhia e paciência ao longo de anos difíceis. 
A meus pais, principais responsáveis por que eu seja o que sou hoje.

Aos professores do mestrado, especialmente aos professores Márcio Nakane e Gilberto Tadeu Lima, pelas valiosas contribuições e atenção sempre que solicitados.

A Valéria e sua equipe, pelo eficiente suporte.

Aos meus colegas de mestrado, dos que certamente guardarei ótimas recordações. Especialmente ao Mário, Andrés e Daniel, pela paciência e companhia nas intermináveis discussões que tanto nos entusiasmam, e pelos comentários e conselhos que muito me auxiliaram na confecção desta Dissertação.

A minha orientadora, professora Leda Paulani, pela compreensão infinita ao longo das tantas idas e vindas que levaram ao trabalho final, e pelo seu constante apoio.

Ao CNPq, pela bolsa de estudos concedida. 


\section{RESUMO}

As taxas reais de juro básicas que têm sido praticadas no Brasil ao longo de um período de já quase quinze anos têm se mantido de forma permanente em níveis extremamente elevados quando comparadas com as taxas historicamente praticadas no país, ou quanto colocadas em uma perspectiva internacional. Neste trabalho, procurou-se proceder a uma análise crítica sistemática das principais teorias sugeridas pelo campo ortodoxo da teoria econômica com o objetivo de explicar a situação excepcional do Brasil, examinando os resultados empíricos por elas obtidos. De um modo geral, a análise conduzida não encontrou evidências satisfatórias capazes de sustentar a relevância ou por vezes a própria validade das teorias examinadas, as quais demonstraram claramente ser tanto teórica quanto empiricamente insuficientes para justificar a manutenção dos níveis das taxas reais de juro praticados no país. Assim, as conclusões e recomendações de política construídas a partir do conjunto de teorias aqui analisado cuja adequação para o caso brasileiro é posta em dúvida neste trabalho devem ser normalmente vistas com reserva.

Por outro lado, procedeu-se a uma análise crítica dos fundamentos teóricos e empíricos sobre os quais se apóia a maneira em que a política monetária tem sido conduzida no país, de forma a verificar se as excepcionais taxas reais de juro brasileiras não decorreriam das necessidades impostas por uma política cujo principal objetivo declarado é manter o controle da inflação. Após proceder ao exame desses fundamentos, não se encontraram na condução da política monetária os elementos que pudessem justificar a particularidade daquelas taxas.

Tendo a abordagem ortodoxa se mostrado globalmente insatisfatória como forma de explicar as taxas reais de juro brasileiras, é introduzida uma abordagem alternativa baseada na economia das convenções, a qual se mostrou a princípio capaz de fornecer bons indicativos para resolver a questão. 


\begin{abstract}
The basic real interest rates which have been in place in Brazil throughout a period of almost fifteen years remained at extremely high levels when compared against those rates historically valid in the country or when placed into an international perspective. This work has tried to proceed to a systematic analysis of the main theories suggested by the economic orthodoxy, which aim to explain the exceptional situation of Brazil, examining the empirical results such theories have obtained. In a general manner, the analysis has not found satisfactory evidences able to support the relevance or even in some cases the validity for the examined theories, which have clearly demonstrated being both theoretically and empirically insufficient to explain the maintenance of the levels of real interest rates in Brazil. Thus, the conclusions and policy recommendations built from such theories whose capacity of fitting to the Brazilian case was challenged in this work must be taken with particular care.

By the other hand, it was performed an analysis on the theoretical and empirical grounds of the manner in which monetary policy was conducted in the country, in order to verify whether the exceptional Brazilian real interest rates could not be originated from the requirements imposed by a policy whose main declared target consists in maintaining the control of the inflation level. After examining those fundamentals, no elements on the monetary policy conduction were found which could justify the peculiarity of those rates.

As the orthodox approach turned to be globally unsatisfactory as a way of explaining the Brazilian real interest rates, it was introduced an alternative approach, based on the economics of conventions, which showed itself as being able at first to provide useful insights to help to solve the question.
\end{abstract}


I. INTRODUÇÃO................................................................................................................ 15

II. JUROS REAIS: DEBATE E CONJECTURAS ................................................. 20

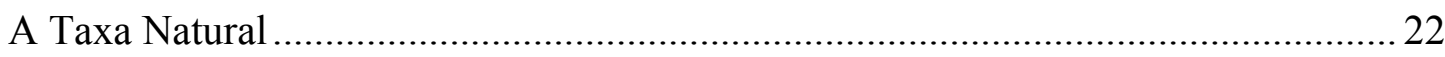

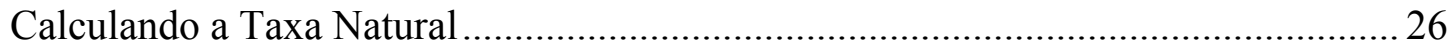

Como tendência da taxa de juros real .................................................................... 26

Como taxa de crescimento do produto potencial ......................................................2 27

Como taxa de equilibrio que elimina o hiato do produto ......................................... 28

Nota sobre o hiato do produto e o cálculo do produto potencial ......................... 30

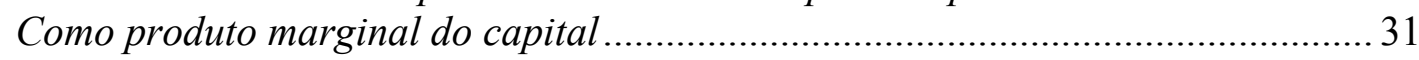

Como taxa implícita na função de reação do Banco Central .................................... 33

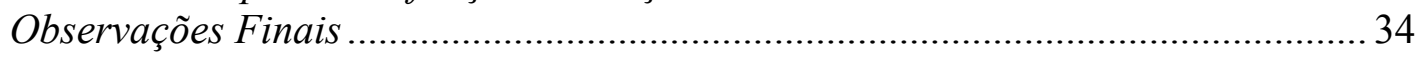

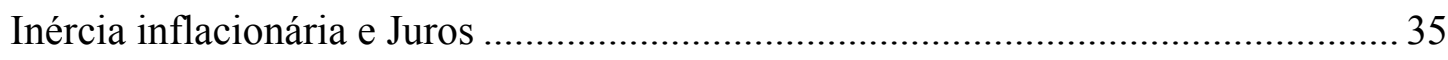

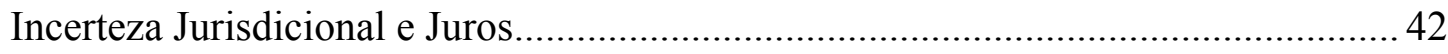

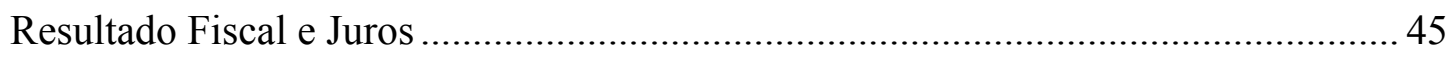

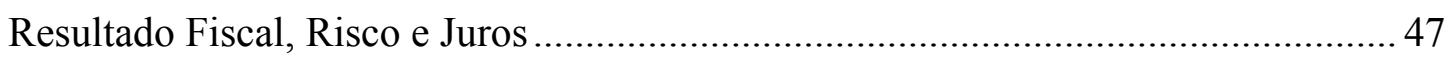

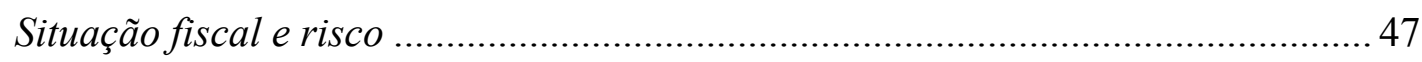

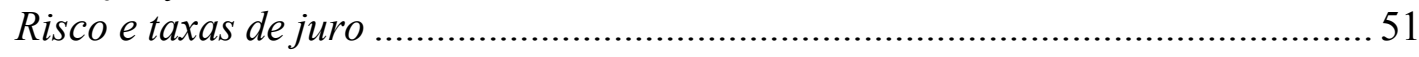

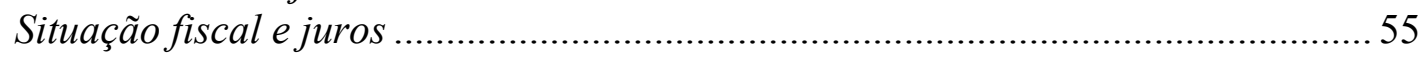

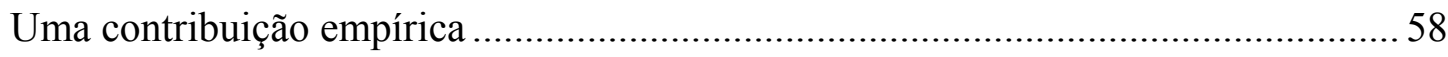

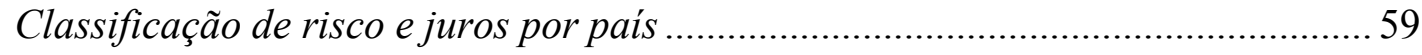

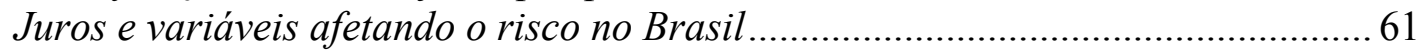

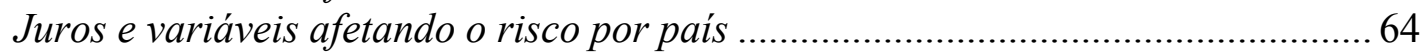

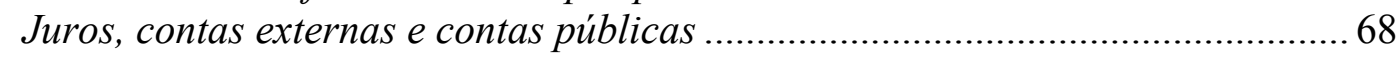

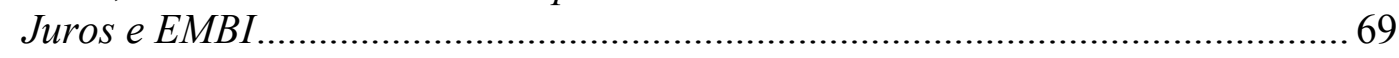

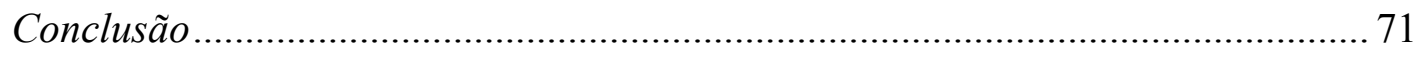

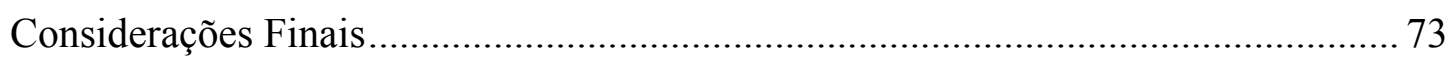

III. POLÍTICA MONETÁRIA E JUROS ......................................................... 76

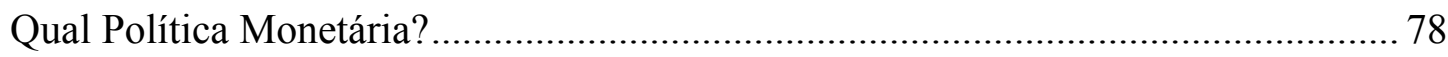

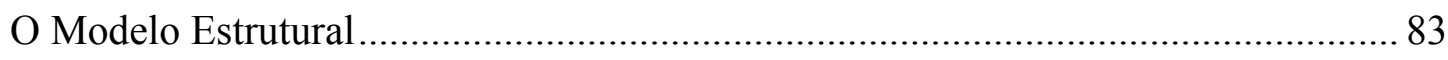

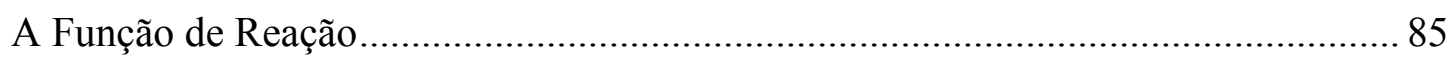

Determinantes das expectativas de inflação .............................................................. 92 


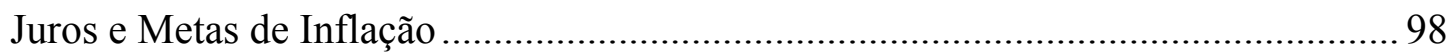

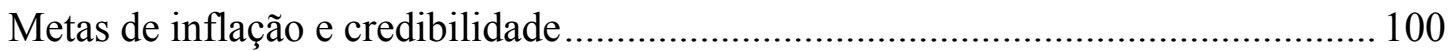

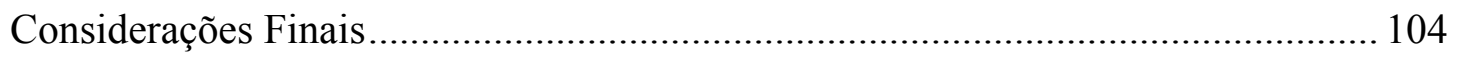

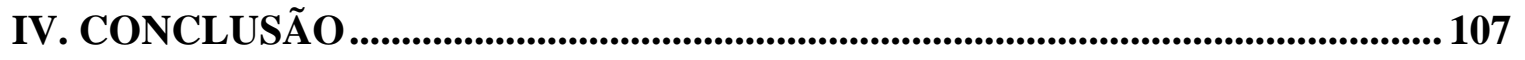

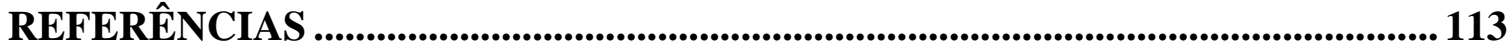




\section{INTRODUÇÃO}

Quatorze anos após o lançamento do Plano Real em 1994, o ano de 2007 inicia-se no Brasil com a meta para a taxa Selic fixada na reunião do Comitê de Política Monetária (COPOM) do Banco Central (Bacen) ocorrida em janeiro, e que se mantém em vigor até a reunião seguinte que terá lugar no mês de março, em 13\% ao ano. Por outro lado, o centro da meta de inflação (IPCA) anual para 2007 fixada pelo CMN (Conselho Monetário Nacional) é de 4,5\%, enquanto que a inflação prevista para o mesmo período por participantes do mercado financeiro e coletada e divulgada pela Gerência-Executiva de Relacionamento com Investidores (Gerin/Bacen) é de 4,07\%.

Definiremos inicialmente a taxa básica anual real de juros $\left(i_{r t}\right)$ vigente no Brasil num dado período como sendo igual à taxa Selic anual $\left(i_{s t}\right)$ definida no mesmo período descontada das expectativas de inflação para os próximos doze meses medidas pelo IPCA $\left(\mathrm{E}\left(\pi_{t+12}\right)\right)$, o que representamos por:

$$
i_{r t}=i_{s t}-E\left(\pi_{t+12}\right)
$$

Esta definição da taxa real se justifica se considerarmos que:

- A taxa Selic, calculada como uma média ponderada e ajustada das taxas praticadas nas operações de financiamento por um dia lastreadas em títulos públicos federais, constitui-se numa taxa básica fundamental para o cálculo das taxas de juros praticadas na maior parte das operações de crédito realizadas no país, além de ser a taxa à qual estão indexados os rendimentos de aproximadamente $50 \%$ dos títulos de dívida pública brasileira.

- A inflação medida pelo IPCA (índice calculado pelo IBGE que representa o consumo médio das famílias com rendimentos entre 1 e 40 salários mínimos) é o parâmetro para o qual as metas de inflação, que pautam a política monetária praticada pelo Bacen, são fixadas.

Assim, ao fazer o cálculo acima, concluímos que 2007 se inicia no Brasil com uma taxa básica real (ou apenas "taxa real") de juros igual a 8,50\% ao ano, se tomarmos como base para a inflação esperada a meta de inflação, ou de $8,93 \%$, quando consideramos a inflação esperada como aquela prevista pelo mercado financeiro. 
Longe de ser uma exceção, a vigência de tais e, inclusive - normalmente - mais elevados patamares para as taxas reais de juros tem sido constante desde a implementação do Plano Real, como pode ser observado no seguinte gráfico:

\section{Gráfico 1}

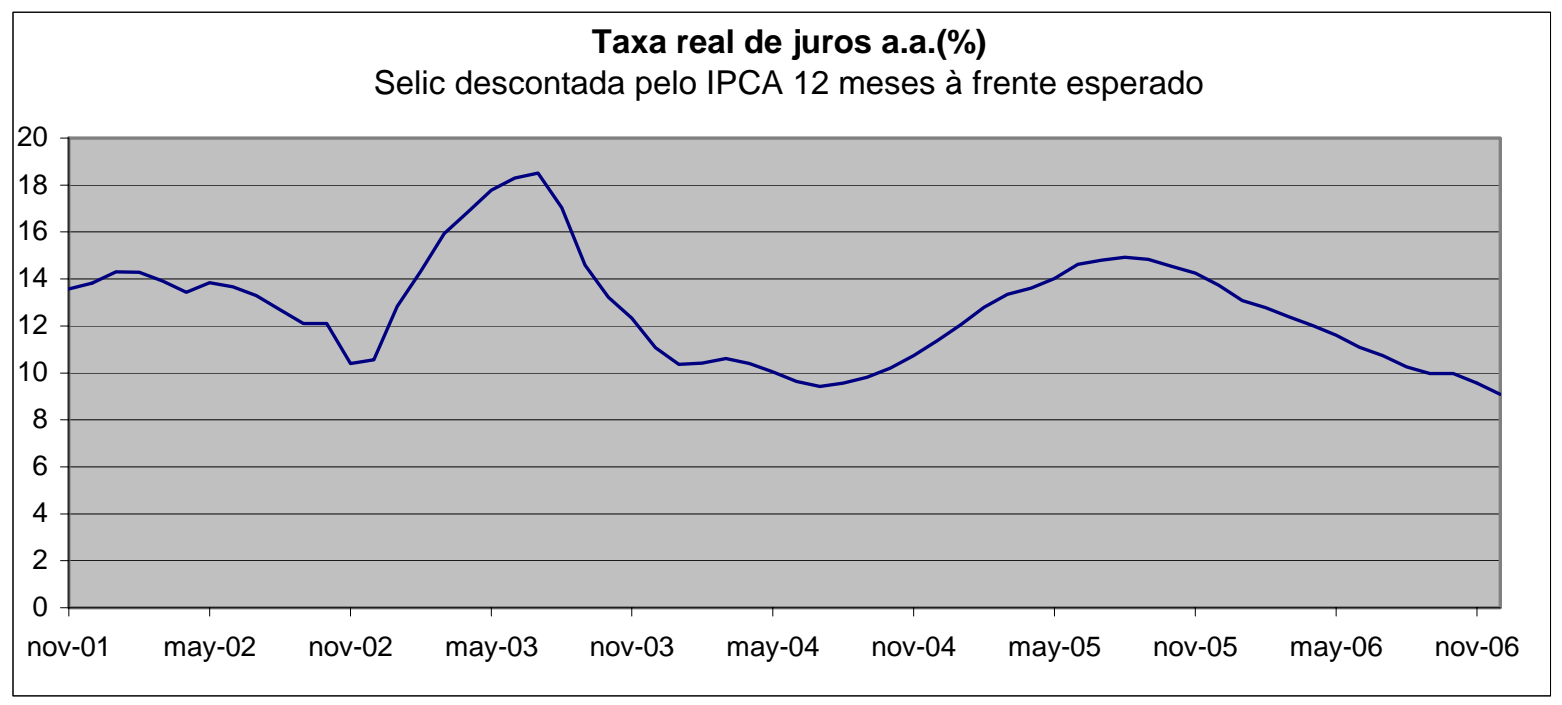

fonte: BCB-GERIN

A taxa real de juros mostrada neste gráfico foi calculada como exposto acima, ou seja, descontando da taxa Selic anualizada vigente as expectativas de inflação para os 12 meses seguintes, mês a mês. Vemos aqui que as taxas esperadas para 2007, apesar de, como veremos mais adiante, elevadas numa perspectiva histórica ou comparação internacional, são de fato menores do que as que têm prevalecido desde o fím de 2001 (início do levantamento das expectativas de mercado para o IPCA acumulado nos próximos 12 meses pelo Bacen), que têm variado entre 10 e $18 \%$.

Entretanto, é interessante comparar as taxas atuais não somente com as praticadas no período mais recente, mas também tentar situá-las numa perspectiva histórica mais longa. Para tanto, uma vez que não dispomos de dados referentes às expectativas de mercado para o IPCA acumulado nos próximos 12 meses para períodos anteriores a novembro de 2001 (quando tais informações começaram a ser coletadas pelo Bacen), o cálculo dos juros reais deve ser feito de outra maneira. Enquanto da forma acima exposta obtemos taxas ex-ante, se descontarmos da taxa Selic anual vigente a taxa verificada (ao invés da taxa esperada) de inflação nos 12 meses seguintes, obteremos uma taxa real de juros ex-post:

$$
i_{r t}=i_{s t}-\pi_{t+12}
$$


Para que possamos considerar as duas taxas como refletindo a mesma variável econômica, sendo assim comparáveis, devemos adotar a hipótese de que as expectativas são normalmente corretas fazendo com que a taxa de inflação efetiva ex-post seja uma boa proxie da inflação esperada ex-ante. Embora tal hipótese seja certamente discutível, se considerarmos que o cálculo da taxa real com uma periodicidade mensal, e que a maior parte das operações que usam a taxa Selic como referência são liquidadas em prazos curtos, os desvios entre as expectativas de inflação e a inflação medida tendem a não ser muito elevados, e seu impacto a ser mais rapidamente corrigido, fazendo com que esta hipótese não deva ser (com a exceção de períodos em que a inflação seja excepcionalmente volátil, em que os desvios das expectativas em relação à inflação medida tendem a aumentar consideravelmente) particularmente problemática na maior parte das aplicações. Assim, podemos calcular as taxas reais de juros a partir de janeiro de 1980, o que nos permite verificar a evolução desta variável num período mais extenso.

\section{Gráfico2}

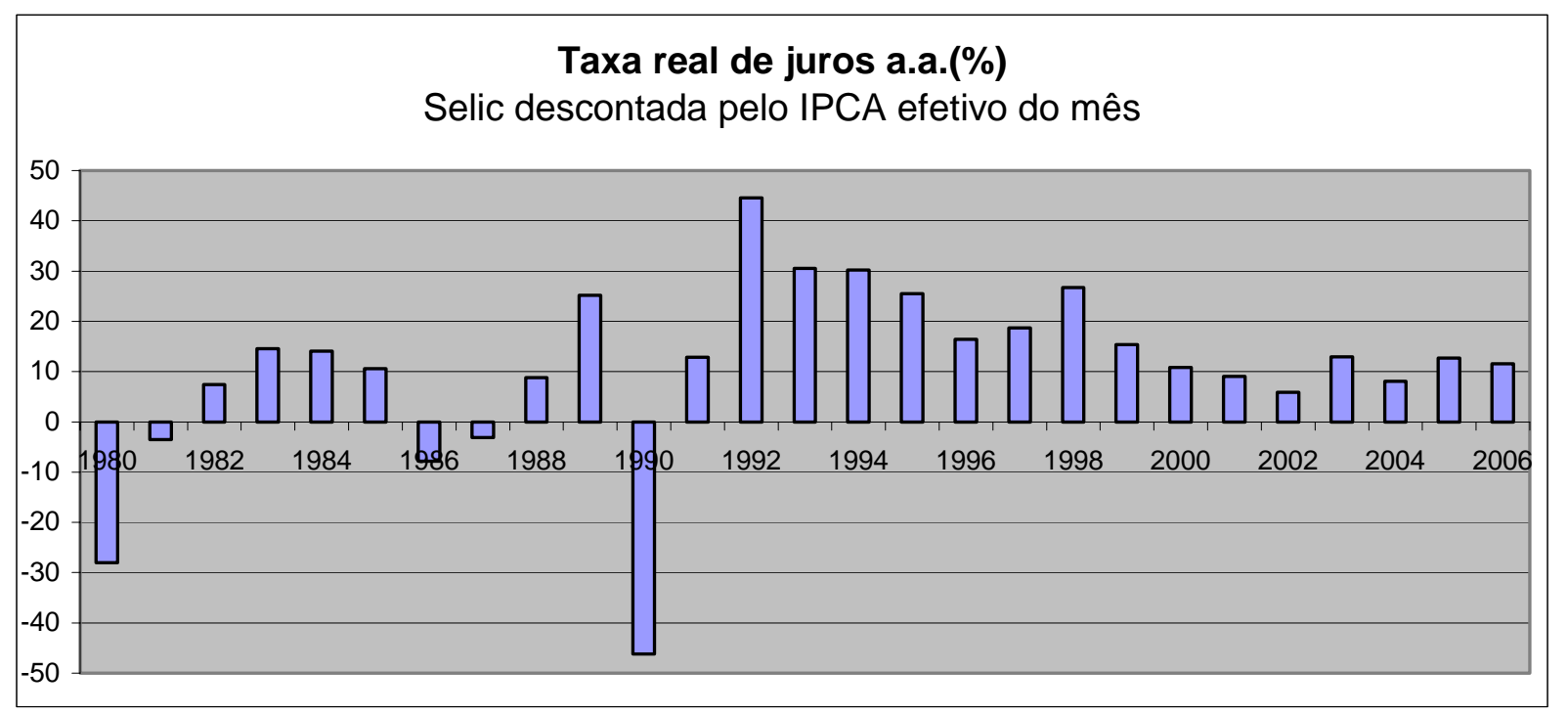

fonte: IBGE e BCB-DEPEC

Vemos aqui que, enquanto no intervalo compreendido entre 1980 e 1993, o qual corresponde a metade do período amostrado, verifica-se uma volatilidade considerável nas taxas reais de juro - as quais correspondem à alta volatilidade apresentada pelas taxas de inflação durante o período -, volatilidade que se traduziu na ocorrência alternada de anos em que se verificaram picos extremos positivos e negativos nas taxas, a partir de 1994, com o lançamento do Plano Real (apesar de que 1992 e 1993 tivessem já apresentado taxas muito elevadas, embora os picos alcançados nestes anos possam ainda ser vistos como parte das violentas flutuações 
ocorridas no início da década de 90), as taxas reais de juros nunca voltaram a tomar valores negativos e têm flutuado, de forma relativamente estável, inicialmente em torno de $30 \%$ ao ano, atingindo picos de 40\%, entre 1994 e 1998, e em torno de 10\% a partir de 1999.

Ao analisar este gráfico podemos concluir que a manutenção de taxas reais de juros positivas e elevadas ao longo de vários anos, praticamente sem interrupção, longe de ser uma característica inerente ao funcionamento normal da economia brasileira, é um fenômeno peculiar, cujo início se situa pouco antes da implementação do Plano Real. Sendo assim, e considerando a importância que as taxas reais de juros têm para o funcionamento da economia, a identificação e compreensão das razões que levaram a esta situação, a qual se mantém até o momento e cuja reversão não parece se vislumbrar num futuro próximo, é um assunto particularmente relevante, que procurarei abordar neste trabalho.

Nos primeiros anos do Real, e até fevereiro de 1999, o controle inflacionário se assentava fundamentalmente no estabelecimento de um sistema de bandas cambiais deslocadas de forma lenta e gradual, que funcionaria como âncora nominal no processo de formação de preços, estabilizando sua evolução. A manutenção de um sistema de crawling peg como este associado a uma maior abertura comercial requer que os eventuais desequilíbrios no balanço de pagamentos, ao não poderem ser ajustados através da flutuação cambial, devam ser resolvidos com a entrada ou saída de capitais, os quais normalmente respondem diretamente a variações nas taxas de juros e considerações de risco. Numa situação como aquela vigente no Brasil durante o período, com a persistência de elevados déficits primários e crescente dívida pública gerando dúvidas sobre a capacidade do governo de sustentá-la, câmbio sobrevalorizado e elevados déficits em transações correntes, além de freqüentes crises de credibilidade e liquidez internacional, a manutenção de altíssimas taxas reais de juros com o objetivo de sustentar a paridade da moeda em relação ao dólar estadunidense era geralmente vista, se aceita a conveniência o regime cambial, como natural e necessária, instigando limitado trabalho acadêmico que a questionasse, pelo menos no campo da teoria ortodoxa, e que discutisse mais profundamente a questão. Entretanto, após o abandono do regime de bandas cambiais e a flutuação do real, e principalmente a partir da experiência posterior à implementação do regime de metas de inflação em junho de 1999 - em que pese o fato de que a sustentação da paridade fixa da moeda não mais estaria no centro do programa de controle inflacionário, as taxas reais de juros vigentes no Brasil continuaram sumamente elevadas para 
padrões internacionais - as reflexões sobre os motivos que justificariam a manutenção destas começaram a ganhar maior espaço no debate acadêmico (Nakano, 2005).

Como contribuição a este debate, procurarei neste trabalho discutir as principais explicações que têm sido desde então avançadas de forma mais freqüente pela teoria econômica ortodoxa com o objetivo de justificar a continuidade da vigência de taxas reais de juros particularmente elevadas no Brasil, buscando apontar as insuficiências de tais explicações. Especialmente, procurar-se-á verificar as razões que justificam os patamares dentro dos quais estas taxas têm flutuado. Para tanto, a discussão será realizada utilizando duas abordagens distintas, tratadas nos dois capítulos a seguir: na primeira delas, a partir da caracterização da excepcionalidade da situação brasileira, serão analisadas as principais teorias que têm sido colocadas pelo campo ortodoxo de forma a justificá-la, assim como discutidos os resultados empíricos que estas teorias têm alcançado, até o momento, nesse sentido. Na segunda abordagem, discutirei as características da política monetária adotada pelo Banco Central nos últimos anos, política esta de caráter basicamente ortodoxo, de forma a identificar em tais características eventuais elementos que possam justificar a manutenção das elevadas taxas reais de juro no Brasil. Finalmente, no último capítulo, como parte da conclusão do trabalho, procurarei introduzir alguns elementos da teoria econômica das convenções que creio possam contribuir, utilizando uma abordagem alternativa à ortodoxa, na explicação das razões que justifiquem a manutenção, ao longo de um período já considerável de tempo, de uma situação singular no que se refere às taxas reais de juro, particularmente prejudicial do ponto de vista do desenvolvimento econômico do país. 


\section{JUROS REAIS: DEBATE E CONJECTURAS}

Como vimos acima, as taxas reais de juros vigentes no Brasil desde o início do Plano Real têm sido particularmente elevadas mesmo quando comparadas com as taxas historicamente praticadas em um país que conviveu na maior parte de sua história com uma crônica instabilidade financeira e monetária. Com isto, e como dificilmente poderia deixar de ser, as taxas praticadas no Brasil são também excepcionalmente elevadas - especialmente se considerarmos que elas assim têm-se mantido ao longo de um já considerável período de tempo - quando comparadas com as taxas praticadas internacionalmente, seja em países desenvolvidos e também em desenvolvimento, que contêm enorme variedade de características institucionais e econômicas, freqüentemente mais desfavoráveis que as brasileiras segundo avaliações convencionais, e em todas as regiões do mundo. Não somente as taxas reais de juros no Brasil têm sido ao longo dos últimos anos normalmente as mais elevadas do mundo - o que certamente não exclui períodos, normalmente curtos, em que países tanto na Europa Oriental (Bulgária, Turquia) quanto na América Latina (Argentina) apresentaram taxas mais altas, ficando nesses casos as taxas brasileiras como as segundas ou terceiras mais elevadas da amostra -, como também a diferença entre as taxas brasileiras e aquelas vigentes em todos os grupos de países tem sido na maior parte do tempo muito significativa. A singularidade da situação brasileira pode ser verificada no seguinte gráfico, construído a partir de dados fornecidos pelo FMI.

Gráfico 3

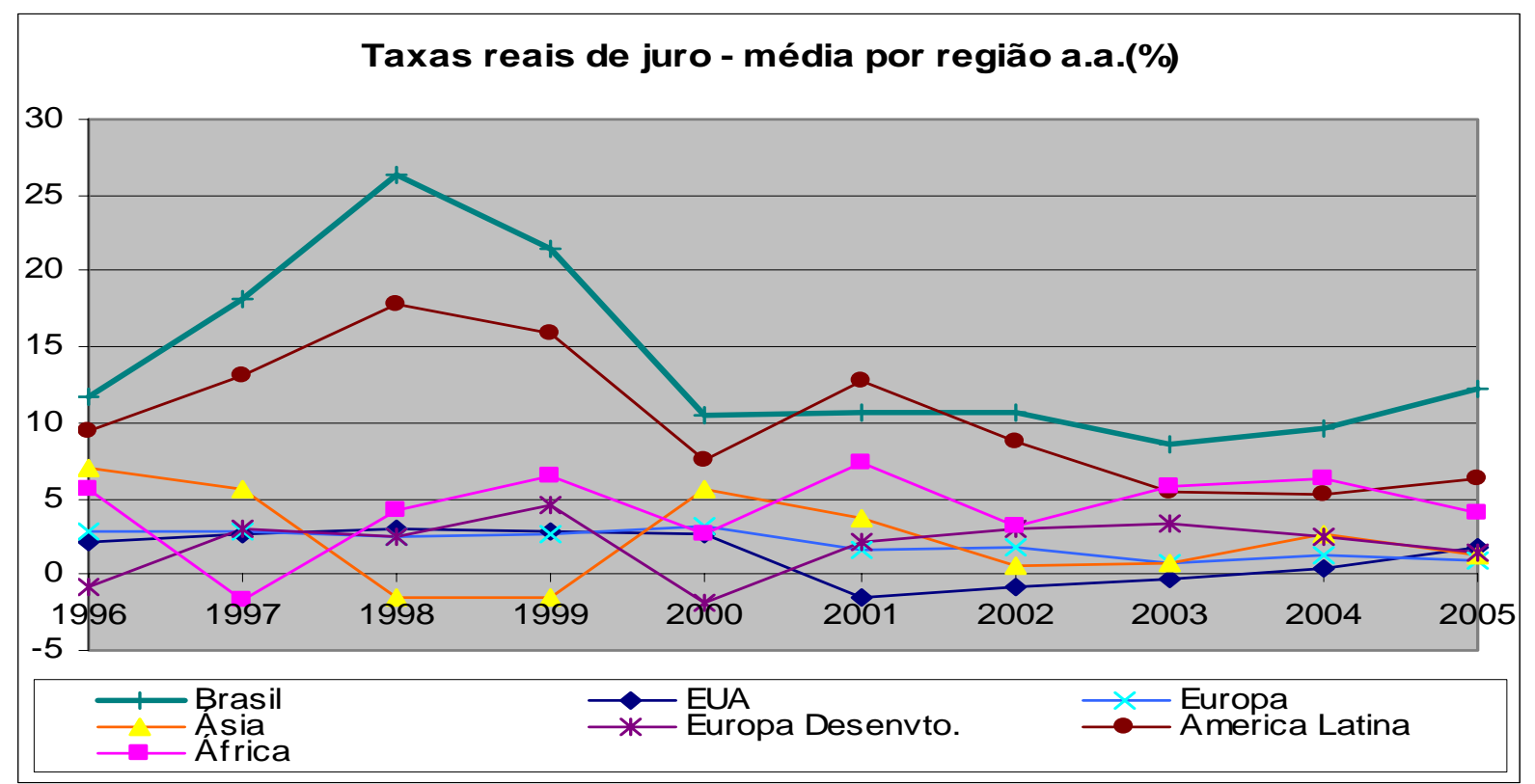

fonte: IFS-FMI 
Neste gráfico, comparamos as taxas reais anuais de juro vigentes no Brasil com a média simples das taxas praticadas em países situados em várias regiões do mundo para os dez anos transcorridos entre 1996 e 2005. O cálculo das taxas é feito de maneira ex-post, simplesmente descontando a taxa anual de inflação da taxa de juros verificada ao final do ano. Vemos que, nesse período (com exceção de 2001, em que a média para a América Latina foi superior), as taxas brasileiras têm se situado significativamente acima da média das taxas calculadas para todas as regiões. E o diferencial das taxas torna-se inclusive maior se a comparação for feita com as demais regiões que não a América Latina.

Entretanto, a comparação com taxas médias dentro de uma região está sujeita à crítica de que estas podem ser significativamente afetadas pela eventual presença de outliers na amostra. Para evitar esse efeito e dar uma melhor medida da particularidade do caso do Brasil, podemos comparar as taxas brasileiras diretamente com as taxas individualmente verificadas para alguns países considerados relevantes. Ao fazer isso, os eventuais outliers são imediatamente identificados, permitindo a análise dos dados sem a distorção que sua presença provocaria ao serem incluídos no cálculo de uma média. Assim, o gráfico a seguir mostra essa comparação em que se incluem várias economias em desenvolvimento situadas ao redor do globo: Egito, Senegal e África do Sul na África, China, Índia, Indonésia, Malásia e Paquistão na Ásia, Croácia, República Tcheca, Hungria, Rússia e Turquia na Europa Oriental, Argentina, Chile, Colômbia e México na América Latina.

\section{Gráfico 4}

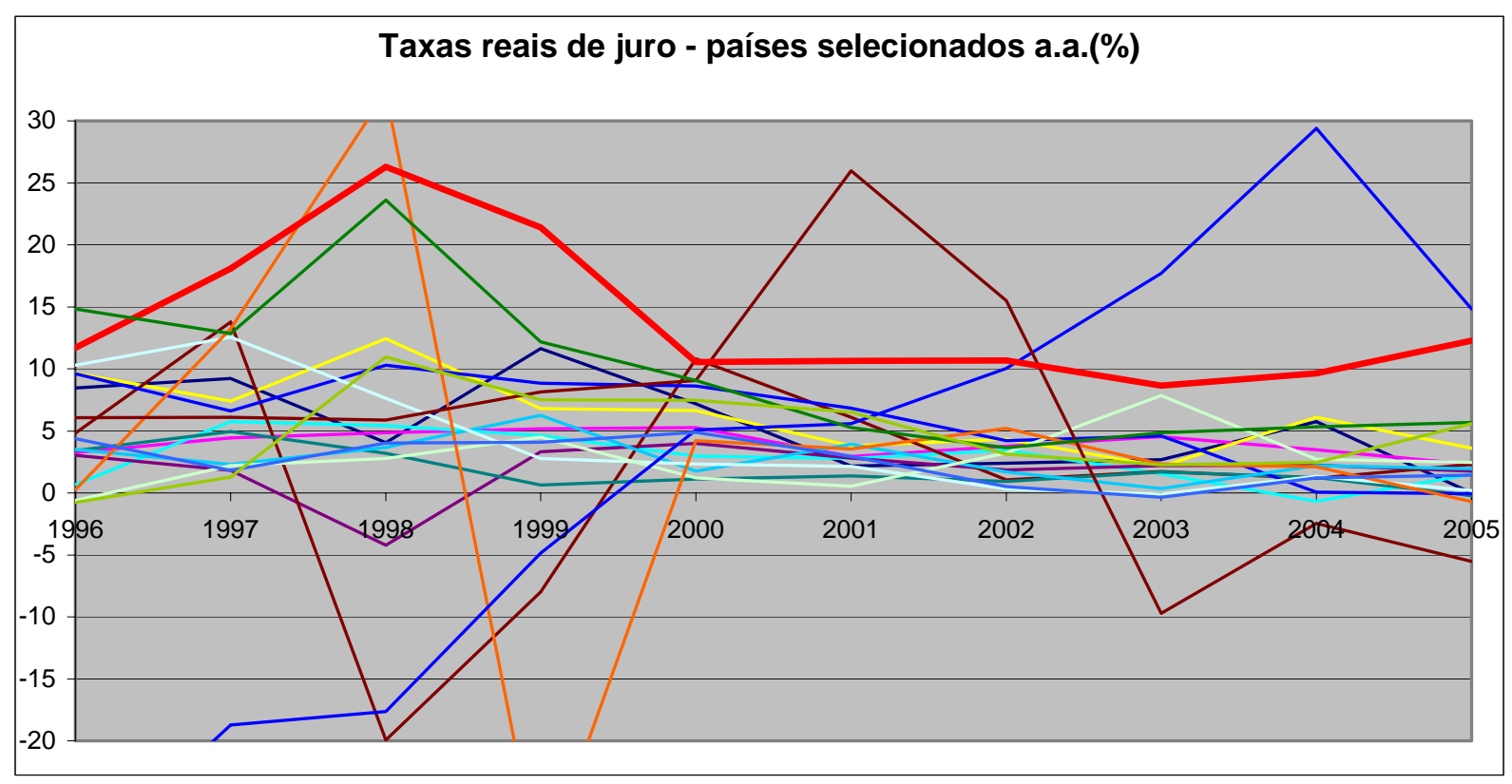

fonte: IFS-FMI 
A análise da evolução das taxas válidas para cada país, dado o elevado número de países selecionados, seria provavelmente confusa e pouca informação acrescentaria a este trabalho; entretanto, o que procuramos ressaltar neste tipo de gráfico é justamente a peculiaridade da situação do Brasil que nele se destaca. De fato, notamos que, com a exceção da Rússia em 1998 e da Argentina em 2001 e 2002 - países que estiveram no centro de importantes crises financeiras internacionais nos anos indicados -, e da Turquia a partir de 2003, as taxas brasileiras (denotadas no gráfico em linha mais espessa) têm sido ao longo do período as mais elevadas dentre os países selecionados, e a diferença com as taxas praticadas na maioria dos demais países tem normalmente sido importante.

A persistência de tal situação levou a que nos últimos anos a teoria econômica tenha crescentemente debatido o assunto e buscado encontrar explicações (Miranda; Muinhos, 2003), as quais têm se mostrado mais ou menos próximas à realidade da qual tentam dar conta. A seguir, discutiremos de forma mais detalhada as explicações para a situação particular do Brasil que têm sido colocadas de forma mais recorrente pelo campo ortodoxo da teoria econômica, procurando verificar sua pertinência. A escolha feita pelo foco nas teorias formuladas por esta vertente não se justifica apenas por atualmente encontrar-se este paradigma em posição dominante como forma de analisar a realidade econômica dentro do ambiente acadêmico, tanto nacional quanto internacional, mas, e de importância central em função dos objetivos deste trabalho, pelo fato de que os formuladores e executores da política econômica no Brasil nos últimos anos, especialmente a política monetária, têm extensamente aderido a seus preceitos, o que faz com que a análise ortodoxa tenha impacto direto e decisivo na realidade.

\section{A Taxa Natural}

A discussão teórica ortodoxa de um modo geral e nas explicações comumente avançadas a partir desse paradigma para o caso brasileiro em particular, normalmente baseia-se no conceito fundamental de taxa natural de juros introduzido por Wicksell (1936), fato pelo qual resulta conveniente iniciar nossa discussão a partir deste conceito. A taxa natural encontra-se definida no texto original de Wicksell de diversas maneiras, mas consistentes entre si:

- como a taxa que igualaria poupança e investimento; 
- como aquela equivalente à produtividade marginal do capital;

- como a taxa compatível com a estabilidade de preços.

A taxa natural tal como definida em qualquer das formas acima geralmente não permanece fixa num valor determinado, mas flutua em função de mudanças estruturais na economia que condicionam o crescimento do produto potencial. Tais mudanças se referem principalmente ao progresso técnico - o qual afeta diretamente a produtividade marginal do capital -, ao crescimento populacional, e à preferência intertemporal das famílias entre consumo hoje e poupança amanhã.

Além desses, outros fatores freqüentemente citados como podendo influenciar a taxa natural de juros seriam:

- a política fiscal e seu impacto na poupança agregada, dado o peso particular do Governo como grande emprestador ou tomador de empréstimos; assim, por exemplo, um aumento no déficit público, se não compensado por um aumento correspondente na poupança privada, levaria ao aumento na taxa natural;

- a estrutura dos mercados financeiros, em que mercados eficientes facilitariam a alocação ótima de recursos garantindo as menores taxas de equilíbrio;

- considerações de risco, que fazem com que ao ser este percebido como maior, a taxa natural também seja mais elevada.

Determinada pelos fatores acima, variáveis no tempo e no espaço, a taxa natural de juros na visão de Wicksell é a taxa real de juros para a qual a economia convergiria no longo prazo conforme as demais variáveis econômicas - principalmente preços e produto - caminhassem em direção a uma situação de equilíbrio.

Definições mais modernas na literatura de modelos de equilíbrio geral Novo-Keynesianos referidos por Woodford (2003) como Neo-Wicksellianos tratam a taxa natural como a taxa real que prevaleceria numa economia fictícia na qual os ajustes nominais são completos, ou, de forma equivalente, como a taxa real de equilíbrio consistente com preços estáveis e hiato do produto nulo, num modelo dinâmico com preços flexíveis e expectativas racionais. Diferentemente do que ocorre na formulação de Wicksell, a taxa natural Novo-Keynesiana 
não é uma taxa para a qual a economia convergiria no longo prazo, não devendo tampouco ser definida como uma taxa de longo prazo; ao contrário, trata-se de uma taxa compatível com o equilíbrio de curto prazo, verificada período a período e para todos os períodos. Neste sentido, o equilíbrio nos modelos Neo-Wicksellianos é compatível com a estabilidade de preços a curto prazo.

Nestes modelos, que têm se tornado influentes nos círculos de formuladores de política monetária de um número crescente de países, a taxa natural de juros e seu conceito derivado de hiato dos juros reais - o interest gap -, definido como a diferença entre a taxa real de juros ex-ante de curto prazo e a taxa natural de juros definida como acima, assumem importância central como indicadores para a definição de política, dado seu papel chave nestes modelos como mecanismo de transmissão de flutuações no produto e inflação (Amato, 2005). De fato, nesse tipo de modelo, caracterizado pela existência de fricções e rigidez nominal de preços levando a ajustes incompletos, a manipulação das taxas nominais de juro, principal - quando não único - instrumento ao alcance do Banco Central, é efetivamente capaz de afetar as taxas reais, uma vez que os preços reagiriam a alterações na taxa nominal apenas de forma lenta e parcial; sendo a taxa real distinta da taxa natural, o interest gap resultante, ao dar origem a discrepâncias entre a demanda agregada e o produto potencial, criaria um hiato do produto não-nulo o qual, por sua vez, conduziria nessa economia a variações nos preços. Desta perspectiva, compreende-se e justifica-se a atuação do Bacen que, quando perseguindo a estabilidade do produto e dos preços, ao constatar uma situação de desequilíbrio com a formação de um interest gap indesejado, atua sobre as taxas nominais de juros buscando afetar as taxas reais, de forma a que estas se igualem à taxa natural, o gap seja eliminado e retorne-se ao equilíbrio do produto e preços. Nesta formulação conclui-se, portanto, que a taxa real de juros depende diretamente e a cada momento da taxa natural ou de equilíbrio, num contexto em que o Bacen atua para atingir esse equilíbrio.

Finalmente, na situação mais extrema, numa economia hipotética com ajustes nominais completos e expectativas racionais como a normalmente considerada em modelos NovoClássicos mais ortodoxos, a taxa real de juros é equivalente à taxa natural, esta também definida período a período, e a economia encontra-se constantemente em equilíbrio. Nesta situação, nunca se configura um interest gap, e não há espaço para a atuação do Bacen, já que este não teria a capacidade - nem necessidade - de afetar as taxas reais. 
De qualquer maneira, seja na versão Wickselliana original, na visão Novo-Keynesiana ou na Novo-Clássica, a taxa natural de juros, variável no tempo e dependente da evolução de variáveis econômicas fundamentais, considerada como taxa à qual a economia convergiria no longo prazo quando esta se dirige ao equilíbrio, como taxa compatível com o equilíbrio no curto prazo quando buscando esse equilíbrio a taxa real é ajustada pelo Bacen, ou como taxa real condizente com uma economia permanentemente em equilíbrio, desempenha um papel fundamental na explicação do nível verificado das taxas reais. Assim, países e períodos específicos nos quais a taxa natural fosse particularmente elevada apresentariam normalmente taxas reais também elevadas.

É importante, entretanto assinalar que, e apesar da importância que tem adquirido como eixo para a definição pelos bancos centrais da taxa real de juros, a taxa natural, não sendo uma variável diretamente observável, apresenta importantes restrições no que se refere à sua utilização como conceito relevante na prática. De fato, diante da incerteza quanto a uma definição operacional única da taxa natural, da dificuldade e imprecisão de sua estimação, e de sua sujeição a importantes erros de medição (Laubach; Williams, 2003), mesmo alguns daqueles que reconhecem a utilidade do conceito como uma maneira de pensar a política monetária colocam significativas ressalvas em relação à sua utilidade prática, sugerindo, por exemplo, substituir a taxa natural como elemento relevante para a condução da política monetária por variáveis observáveis tais como a inflação medida (Amato, 2005); negando sua utilidade como número base para aplicação de uma regra mecânica (Blinder, 1998); e diluindo sua importância na formulação de política monetária ao colocar a taxa natural e conceitos derivados como o interest gap como apenas algumas entre muitas ferramentas que o Bacen deve usar (Quaresma et al, 2005). Tais dificuldades são exemplificadas neste último trabalho que, ao revisar estimações da taxa natural de juros feitas para países da zona do Euro, constata empiricamente que a utilização de distintos métodos conduz a valores significativamente diferentes, colocando dúvidas quanto à sua adequação prática na formulação da política.

Entretanto, como previamente afirmado, e apesar das restrições colocadas em relação à sua utilização na prática, a idéia de taxa natural, com sua compatibilidade com a visão de equilíbrio dominante na teoria econômica, encontra-se na base de praticamente todas as tentativas ortodoxas de explicar a manutenção das elevadas taxas reais de juros vigentes no Brasil. Nessa visão, tais taxas reais corresponderiam justamente a uma taxa natural que também seria particularmente elevada quando comparada às taxas verificadas nos demais 
países. Para poder afirmar que tal explicação é correta, entretanto, deveria ser possível calcular a taxa natural brasileira e verificar sua eventual singularidade. Na próxima seção discutiremos diferentes métodos relacionados pela teoria ortodoxa que justamente procuram estimar a taxa natural de juros, comparando quando possível os resultados encontrados para o Brasil com aqueles obtidos, usando os mesmos métodos, para outros países, procurando dessa forma constatar essa singularidade e, a partir disso, tentar identificar as razões que levam a essa situação.

\section{Calculando a Taxa Natural}

Dado que, como acima exposto, diferenças na taxa real de juros são explicadas na visão ortodoxa explícita ou implicitamente se referindo a diferenças na taxa natural de juros, veremos nesta seção exemplos de como esta taxa tem sido calculada e até que ponto os resultados normalmente encontrados são satisfatórios e capazes de justificar o elevado nível das taxas reais no Brasil. Esta parte do trabalho baseia-se em boa medida no recente estudo empírico apresentado por Muinhos e Nakane (2006) que, com seu foco na verificação das teorias normalmente utilizadas para justificar a singular situação do Brasil, constitui-se numa relativa exceção, uma vez que, apesar da crescente literatura sobre o assunto difundida nos últimos anos e de, por exemplo, grande quantidade de trabalhos que buscam estimar a função de reação do Bacen, não se encontram estudos empíricos igualmente abrangentes que coloquem a permanência de elevadas taxas reais de juro ao longo de vários anos como uma questão em si a ser investigada.

\section{Como tendência da taxa de juros real}

No trabalho acima citado, Muinhos e Nakane utilizam uma variedade de métodos de estimação procurando encontrar a taxa natural (ou de equilíbrio) e comparar os dados obtidos para o Brasil com os dados referentes a outros países. O primeiro desses métodos consiste em simplesmente filtrar as taxas reais de juros ex-post dos movimentos referentes a choques transitórios. Uma vez estes eliminados, as taxas reais efetivas seriam uma aproximação da taxa natural. Utilizando este método o trabalho mostra, com dados entre 1992 e 2002 para 18 países em desenvolvimento, as taxas brasileiras como sendo as segundas maiores no período 
(atrás apenas das do Peru) entre os países da amostra. Entretanto, tal tipo de estudo não é evidentemente capaz de fornecer elementos que expliquem as diferenças encontradas, apenas constatando-as. As taxas reais aqui obtidas servirão como benchmark para comparar as taxas estimadas pelos métodos apresentados a seguir.

\section{Como taxa de crescimento do produto potencial}

O segundo método utilizado no artigo consiste em diretamente associar a taxa natural à taxa de crescimento do produto potencial, procedimento usado por vários bancos centrais, e cujo significado é aceito, por exemplo, pelo Banco Central do Brasil (Bogdansky et al, 2000). Esta idéia justifica-se ao considerarmos que se a taxa real de juros fosse diferente da taxa de crescimento do produto potencial, existiriam oportunidades de arbitragem que corrigiriam essa diferença; sua sustentação não seria, portanto consistente com o comportamento racional. $\mathrm{Na}$ tabela abaixo, são expostos os resultados obtidos, comparando-os com as taxas calculadas a partir da tendência filtrada. Vemos que, com este método, a taxa natural média para o Brasil entre 1992 e 2002, de 3,04\%, encontra-se abaixo, por exemplo, da taxa calculada para o Chile, de 4,8\%, e da média da Europa Oriental (3,7\%), e apenas ligeiramente acima da média dos países em desenvolvimento (2,95\%), e isto ocorrendo apesar de apresentar taxas reais de juros muito superiores. De fato, quando as taxas reais obtidas pelo método anterior são comparadas com as taxas de crescimento do produto potencial, vemos que estas são pouco menores (em torno de $1 \%$ ) do que as primeiras no caso dos países do sudeste asiático, e o contrário - com exceção da Croácia - ocorrendo no caso da Europa Oriental, mas com diferenças maiores (o que se deve à vigência em alguns períodos de taxas reais negativas na região); já no caso da América Latina, com exceção do Equador, a diferença se dá no mesmo sentido que na Ásia, ou seja, taxas reais maiores do que as do crescimento do produto potencial, mas com a diferença média da região sendo significativamente maior ( 6 a 7\%, dependendo do período) que no caso da Ásia, o que se deve basicamente ao Peru, à Argentina após 1999, e ao Brasil (10 a 15\%). Desta discussão podemos concluir que o crescimento do produto potencial não se revelou na análise geral (e particularmente para países da América Latina) como um bom previsor da taxa de juros real, não parecendo ser um dos seus determinantes fundamentais. Além disso, a diferença especialmente elevada (9,36\%) constatada entre o valor assim calculado e as taxas reais ex-post obtidas no item anterior para o caso do Brasil aponta para 
uma utilidade ainda menor quando comparada contra outros países que o crescimento do produto potencial parece ter para explicar as taxas reais de juros brasileiras.

Tabela 1

\begin{tabular}{|c|c|}
$\begin{array}{c}\text { Tendência } \\
\text { Filtrada }\end{array}$ & $\begin{array}{c}\text { Produto } \\
\text { Potencial }\end{array} \quad$ Diferença \\
\hline
\end{tabular}

\begin{tabular}{|l|}
\hline Países Emergentes \\
\hline Sudeste Asiático \\
\hline Coréia \\
\hline Indonésia \\
\hline Filipinas \\
Tailândia \\
\hline
\end{tabular}

\begin{tabular}{|c|c|}
\hline $\mathbf{4 , 2 7}$ & $\mathbf{2 , 9 5}$ \\
\hline $\mathbf{4 , 0 0}$ & $\mathbf{2 , 5 3}$ \\
\hline 4,80 & 5,20 \\
4,00 & $(0,50)$ \\
4,80 & 3,70 \\
2,50 & 1,70 \\
\hline
\end{tabular}

\begin{tabular}{|l|}
\hline América Latina \\
\hline Argentina \\
Brasil \\
\hline Chile \\
Colômbia \\
México \\
Equador \\
Peru \\
\hline
\end{tabular}

\begin{tabular}{|c|c|}
\hline $\mathbf{8 , 4 0}$ & $\mathbf{2 , 6 0}$ \\
\hline 4,40 & 0,75 \\
$\mathbf{1 2 , 4 0}$ & $\mathbf{3 , 0 4}$ \\
$\mathbf{4 , 1 0}$ & 4,80 \\
3,80 & 1,20 \\
5,70 & 3,00 \\
6,00 & 1,20 \\
20,00 & 3,90 \\
\hline
\end{tabular}

\begin{tabular}{|c|}
\hline $\mathbf{( 5 , 8 0 )}$ \\
\hline$(3,65)$ \\
$\mathbf{( 9 , 3 6 )}$ \\
0,70 \\
$(2,60)$ \\
$(2,70)$ \\
$(4,80)$ \\
$(16,10)$ \\
\hline
\end{tabular}

\begin{tabular}{|c|c|c|c|}
\hline Europa Oriental & 0,40 & 3,73 & 3,33 \\
\hline Croácia & 4,90 & 3,20 & $(1,70)$ \\
\hline República Tcheca & 2,40 & 1,60 & $(0,80)$ \\
\hline Estônia & $(6,50)$ & 5,10 & 11,60 \\
\hline Letônia & - & 5,40 & - \\
\hline Lituânia & $(0,30)$ & 3,20 & 3,50 \\
\hline Turquia & 1,90 & 2,94 & 1,04 \\
\hline
\end{tabular}

\section{Como taxa de equilibrio que elimina o hiato do produto}

Outro método usado no trabalho buscando obter a taxa natural de juros consiste em encontrar a taxa real de equilíbrio que elimina o hiato do produto, o que pode ser obtido através da estimação de uma curva IS, em que o hiato contemporâneo do produto é função do hiato no período anterior, da taxa real de juros, e de outras variáveis explicativas; remanejando a equação estimada, obtemos a taxa que procuramos. Usando o nível de exportações, o influxo de capital e dummies sazonais, o artigo estima a taxa real de equilíbrio para 17 países, no período entre 1992 e 2002, e para um subconjunto com esses mesmo países no período entre 1998 e 2002. Analisando os resultados, vemos que, enquanto em alguns casos os valores mostrados são efetivamente consistentes com as taxas ex-post estimadas e acima 
apresentadas, em vários outros as discrepâncias são muito significativas, restando outros ainda em que os resultados, por demais extremos, não são confiáveis.

Apesar destes problemas e da decorrente desconfiança em considerar tais resultados como representativos de alguma taxa de equilíbrio, não recomendando, portanto, sua generalização, chama a atenção o fato de que os resultados estimados para o Brasil, entre 11\% (para todo o período) e 13\% (apenas para o período mais curto), são os terceiros (atrás apenas dos valores relativos ao Equador e ao Peru) mais elevados da amostra, e são, nos dois casos, compatíveis com as taxas reais efetivamente praticadas.

Resultados compatíveis (embora com taxas reais menores) obtidos exclusivamente para o Brasil são também encontrados no trabalho de Barcellos e Portugal (2006), que obtêm a taxa natural de juros como a taxa de equilíbrio que estabiliza os preços (evoluindo em torno da meta de inflação) e o produto (hiato nulo) período a período, em um modelo macroeconômico simplificado representado basicamente por duas equações, de demanda (também uma curva IS) e oferta (curva de Phillips) agregada (Woodford, 2003), onde são feitas as hipóteses, seguindo os modelos Neo-Wicksellianos acima discutidos, de que: a) o hiato do produto converge a zero quando o interest gap visto acima é zero, e b) flutuações na inflação convergem a zero quando o hiato do produto é zero. Após construir e estimar o modelo, a média da taxa natural encontrada para o período entre Set/1999 e Set/2005 foi de 9,62\%, próxima, portanto, dos valores reais efetivamente verificados, embora mostrando importantes variações entre os valores encontrados, por exemplo, no final de 2003 (5\%) e no início do segundo semestre em 2005 (12,5\%), o que aponta para uma elevada instabilidade na medida.

A despeito desta variabilidade, os resultados encontrados poderiam sugerir que, pelo menos para o caso do Brasil, o hiato do produto seria um elemento importante na explicação das taxas reais de juros. No entanto, esta conclusão não somente é posta em dúvida pelo fato de não poder, como visto pela análise dos resultados do trabalho de Muinhos e Nakane, em geral ser estendida satisfatoriamente a outros países, mas também por depender crucialmente e ser extremamente sensível à maneira pela qual o hiato do produto, variável não observada diretamente, é calculado. E, como veremos a seguir, o procedimento com que este cálculo é normalmente efetuado merece importantes considerações. 
O hiato do produto, magnitude que assume papel fundamental na determinação do nível de equilíbrio da taxa real de juros - equivalente em tal situação à taxa natural, buscada nesta seção - em modelos Novo-Keynesianos formulados em grande quantidade de trabalhos recentes, é normalmente obtido apurando-se a diferença entre o produto efetivo medido e o produto potencial, sendo que este é normalmente calculado como a tendência histórica do produto filtrada das flutuações cíclicas e sazonais, usando uma variedade de filtros, dos quais o mais utilizado é o filtro Hodrick-Prescott (HP). Este tipo de filtro decompõe as séries temporais em seus componentes de tendência e ciclo (no caso do filtro HP), permanentes e transitórios, seculares e irregulares ou sazonais, dependendo do filtro usado. A utilização deste tipo de filtro, conveniente por sua simplicidade e facilidade de utilização em comparações internacionais, apresenta entretanto na maioria dos casos uma série importante de pontos negativos (Souza Junior, 2005):

- aceitação da existência de um valor tendencial em torno do qual a série naturalmente flutua; no caso do produto, se aceita a hipótese de que o produto necessariamente flutua em torno de um produto potencial;

- arbitrariedade na escolha dos parâmetros que definem a maneira de separar a tendência do que é temporário (o parâmetro de suavização no filtro HP);

- imposição da simetria do hiato relativo, ou seja, que a soma dos hiatos ao longo de toda a série seja igual a zero;

- viés de final da amostra, em que os valores filtrados são mais sensíveis aos valores finais da amostra, fazendo com que, se estes não representarem adequadamente a tendência, subestimem ou superestimem a série;

- arbitrariedade na definição do período a compor a amostra, principalmente no que se refere ao período inicial a partir do qual a tendência é construída, e pela possibilidade de que o período usado contenha características específicas relevantes, que podem definir a tendência da série filtrada, mas que são pouco relevantes ao visualizar períodos mais prolongados.

Estas importantes ressalvas, freqüentemente ignoradas em trabalhos empíricos, deveriam implicar na adoção de grande prudência e cuidado redobrado na utilização deste tipo de filtros para a obtenção de séries de dados não diretamente observáveis, assim como uma postura em 
geral conservadora em relação às conclusões de modelos cujos resultados são particularmente sensíveis a alterações em variáveis obtidas a partir da aplicação de filtros, o que ocorre, por exemplo, com os modelos utilizados nos dois trabalhos, acima apresentados, que se baseiam no produto potencial como peça chave para a estimação das taxas naturais de juros. Para o caso do Brasil, particularmente, a confiabilidade da estimação do produto potencial por meio de filtros é altamente discutível, especialmente ao considerarmos que as condições macroeconômicas que têm prevalecido no país ao longo de mais de duas décadas foram marcadas por sucessivos choques externos, programas econômicos do Governo intervindo decisivamente no funcionamento da economia e, como parte do último programa de estabilização implementado, a própria manutenção ao longo de mais de uma década (e não somente até 1999, com o regime de câmbio fixo, como freqüentemente reconhecido) de taxas de juros reais extremamente elevadas. Nestas condições tão particulares, que incluem elevada quantidade de intervenções exógenas, resulta difícil aceitar uma série filtrada como representando adequadamente o produto potencial do país. Diante disto, resultados de modelos que sejam por demais sensíveis às variações no produto potencial estimado, como os normalmente utilizados na análise da política monetária, deveriam ser encarados com especial cuidado. Este é, por exemplo, o caso dos modelos usados pelo Bacen, que têm influenciado decisivamente a definição da política monetária, calibrados com base em estimações do produto potencial realizadas com a utilização do filtro HP. (Bogdansky et al, 2000)

\section{Como produto marginal do capital}

Um quarto método a partir do qual taxa natural de juros pode ser diretamente estimada é o que considera que esta deva ser igual ou próxima ao retorno real do capital, do qual uma medida sugerida seria seu produto marginal. De fato, se não fosse assim, a alocação dos capitais não estaria em equilíbrio e sua própria movimentação se encarregaria de desfazer essa situação. Assim, por exemplo, se a taxa real de juros fosse superior ao produto marginal do capital, o volume de capital destinado a investimentos reduzir-se-ia, forçando a taxa real para baixo; se a taxa fosse menor, o contrário ocorreria. Somente quando a taxa real igualasse o produto marginal do capital, o equilíbrio seria alcançado. A taxa real de juros nesta situação corresponderia à taxa natural. $\mathrm{O}$ estudo de Muinhos e Nakane procura estimar a taxa natural de juros desta maneira, utilizando duas medidas distintas para o produto marginal do capital, os produtos bruto e líquido. A diferença entre ambos decorre do fato de que o produto bruto, 
derivado diretamente a partir da estimação de uma função de produção contendo como variáveis as quantidades de capital físico, capital humano e trabalho, além da produtividade do trabalho e da proporção devida ao capital no produto, pode não dar uma medida suficientemente precisa do retorno do capital devido ao fato de que diferentes países podem usar de forma mais ou menos eficiente o capital disponível, alocando uma parcela maior ou menor em atividades de rent-seeking. Para solucionar esse problema, no cálculo do produto líquido este tipo de atividades é modelada de forma a tomar as ineficiências decorrentes em consideração durante a estimação.

Seguindo este método, os resultados encontrados para o ano de 2000, apresentados na tabela abaixo, mostram um produto marginal do capital bruto em torno de $15 \%$ para o Brasil, o que representa um valor não muito distante do que seria esperado para um país pertencendo ao subgrupo de países com nível intermediário de renda por trabalhador - dentre os 75 países para os quais foram feitos os mesmos cálculos - e com nível de capital por trabalhador como o apresentado pelo Brasil. Por outro lado, quando verificamos os resultados do produto marginal do capital líquido também para o ano de 2000, verificamos que o valor estimado para o Brasil é de $10 \%$, número também compatível com os valores obtidos para os demais 64 países para os quais o cálculo foi realizado, se considerarmos as características do Brasil no que se refere ao capital por trabalhador.

Tabela 2

\begin{tabular}{|c|c|}
\hline Gross & Net \\
$\begin{array}{c}\text { Marg.Prod.of } \\
\text { Capital }\end{array}$ & $\begin{array}{c}\text { Marg.Prod.of } \\
\text { Capital }\end{array}$ \\
\hline
\end{tabular}

\begin{tabular}{|l|c|c|}
\hline \multicolumn{2}{|l|}{ Sudeste Asiático } \\
\cline { 3 - 3 } Coréia & $11,77 \%$ & $7,62 \%$ \\
Indonésia & $20,10 \%$ & $9,67 \%$ \\
Malásia & $16,26 \%$ & $12,26 \%$ \\
Filipinas & $18,74 \%$ & $11,28 \%$ \\
Tailândia & $10,90 \%$ & $7,28 \%$ \\
\hline
\end{tabular}

\begin{tabular}{|l|c|c|}
\hline \multicolumn{2}{|l|}{ América Latina } \\
\cline { 2 - 3 } Argentina & $14,30 \%$ & $8,58 \%$ \\
Brasil & $\underline{\mathbf{1 4 , 7 9 \%}}$ & $\mathbf{1 0 , 0 6 \%}$ \\
\hline Chile & $\mathbf{1 8 , 3 0 \%}$ & $\mathbf{1 5 , 1 2 \%}$ \\
Colômbia & $23,10 \%$ & $13,15 \%$ \\
Equador & $13,41 \%$ & $6,98 \%$ \\
México & $16,01 \%$ & $9,99 \%$ \\
Peru & $12,39 \%$ & $7,98 \%$ \\
Venezuela & $13,36 \%$ & $6,95 \%$ \\
\hline \multicolumn{2}{|c|}{ Fonte: citado em Muinhos\&Nakane, 2006. }
\end{tabular}

Fonte: citado em Muinhos\&Nakane, 2006. 
Assim, nenhuma diferença relevante pôde ser constatada, usando esta metodologia, entre o Brasil e os demais países da amostra, no que se refere à medida da produtividade marginal do capital. Portanto, aparentemente não é possível explicar, baseando-se em diferenças neste tipo de medida, a singularidade do país em relação às elevadas taxas reais de juro. Assim, e apesar de que o valor alcançado pelo produto marginal líquido pareça ser consistente com as taxas reais de juro que vêm sendo praticadas no Brasil, ao verificar os dados para vários países, o estudo não mostra que as relações entre as duas variáveis sejam significativas.

\section{Como taxa implícita na função de reação do Banco Central}

Finalmente, o último método que aqui discutiremos, usado por exemplo no artigo de Barcellos e Portugal (2006), consiste na estimação da taxa natural de juros implícita na função de reação do Banco Central. A função de reação relaciona a variável instrumento de política monetária ao alcance direto do Bacen, fundamentalmente a taxa de juros nominal de curto prazo, às variáveis econômicas relevantes que ele pretende manter sob controle. Se os objetivos fixados para a autoridade monetária são estabilizar a inflação e o produto na economia, então a taxa de juros deve responder aos desvios da inflação e do produto em relação aos valores desejados, considerados de equilíbrio (Taylor, 1993). Tais valores seriam normalmente o hiato do produto e, num sistema de metas, a meta de inflação escolhida.

Existem diversas especificações possíveis para a função de reação, as quais serão mais bem discutidas no próximo capítulo. Numa dessas formulações, em que a inflação e o produto aparecem na forma de desvios da meta e do produto potencial respectivamente, temos que, se tomarmos tais desvios como sendo normalmente nulos, o intercepto pode ser entendido como a taxa real de equilíbrio (Clarida et al, 1999). Considerando que os bancos centrais procuram estabilizar a inflação e o produto em torno dos valores de equilíbrio, o intercepto da equação estimada representaria a taxa de equilíbrio implícita nas decisões de política monetária tomadas pelo Bacen.

Com este objetivo, Barcellos e Portugal estimam a função de reação do Bacen no Brasil e obtêm uma taxa real implícita média de 7,38\% entre 2000 e 2005. Soares e Barbosa (2006) por sua vez, também com dados entre 2000 e 2005, a partir da mesma idéia mas usando uma especificação distinta com diferentes variantes, obtêm taxas reais entre 8 e 10\%, segundo o 
caso. Nota-se aqui que as taxas estimadas com estes métodos encontram-se bastante próximas (embora um pouco abaixo, principalmente no estudo de Barcellos e Portugal) das taxas reais efetivamente verificadas ex-post com o primeiro método apresentado. Este fato não fornece, entretanto, explicações para a ocorrência de taxas excepcionalmente elevadas, mas apenas indica, no caso de o modelo mostrar um ajuste razoavelmente bom aos dados, e se for geralmente aceito (ou explicitamente reconhecido) que o Bacen toma suas decisões em boa medida apoiado em modelos contendo uma função de reação como a aqui discutida, a taxa natural que o Bacen teria considerado como adequada em suas ações. A partir disto, o que poderíamos eventualmente concluir é que as taxas reais de juro vigentes no Brasil podem ser resultado da utilização, na regra de política monetária que motiva as decisões tomadas pelo Bacen, de considerações que aceitem como válida uma taxa natural de juros particularmente elevada, taxa que, entretanto não encontra fundamentação empírica suficiente com os métodos de estimação até aqui empregados. Esta questão será discutida de forma mais detalhada no próximo capítulo.

\section{Observações Finais}

Como conclusão da discussão realizada até o momento, notamos que as taxas reais de juros excepcionalmente elevadas vigentes no Brasil não puderam ser satisfatoriamente explicadas a partir da suposta existência de significativas diferenças existentes entre a taxa natural de juros válida para o país e aquelas verificadas em outros países, já que a taxa natural, pelo menos nas formas em que foi diretamente calculada no estudo apresentado, como sendo equivalente:

- à taxa de crescimento do produto potencial;

- à taxa de equilíbrio que elimina o hiato do produto;

- ao produto marginal do capital;

não se mostrou convincentemente relacionada às taxas reais de juro efetivamente ocorridas.

Com efeito, as comparações internacionais realizadas a partir dos dados obtidos de vários países para cada uma destas distintas maneiras de medir a taxa natural de juros não apontaram para diferenças significativas entre eles que nos permitissem encontrar as explicações que buscamos. Estas, portanto, deverão ser buscadas de uma outra forma. 
Entretanto, é possível, ainda dentro do paradigma das taxas naturais, continuar procurando tais explicações. Mantendo a idéia de que são variações na taxa natural as que explicariam as notáveis diferenças verificadas nas taxas reais de juros, e em particular o caso singular do Brasil, vários trabalhos têm se focado sobre alguns fatores que, apesar de importantes, não seriam, contudo captados por estimações diretas da taxa natural tais como as apresentadas nos trabalhos acima, mas que, entretanto, influenciariam de forma decisiva essa taxa, determinando assim também as taxas reais de cada país. Portanto, ao invés de tentar derivar diretamente a taxa natural a partir de conceitos como aqueles utilizados acima e, a partir das diferenças assim encontradas, explicar as variações nas taxas reais de juros, procedimento que, conforme vimos, não apresentou resultados satisfatórios, discutiremos distintas maneiras de explicar as taxas reais que, sem pretender obter estimativas das taxas naturais, apontariam entretanto para alguns fatores decisivos em sua determinação que seriam portanto capazes de explicar suas variações.

Abordaremos a seguir quatro abordagens que têm sido as mais comumente sugeridas na literatura para explicar a singularidade das taxas de juro vigentes no Brasil. Elas referem-se a medidas relativas:

- à característica inercial da inflação brasileira;

- à incerteza jurisdicional;

- ao resultado fiscal;

- a variações na percepção de risco.

Nas próximas seções analisaremos os pontos acima, examinando alguns trabalhos que têm discutido e eventualmente procurado verificar a validade empírica de cada uma das possibilidades avançadas.

\section{Inércia inflacionária e Juros}

O primeiro fator que discutiremos, e que tem sido freqüentemente evocado para justificar a manutenção das elevadas taxas reais de juro no Brasil, refere-se à suposta particular persistência do processo inflacionário brasileiro, ou seja, a avaliação de que ele conteria um 
importante componente inercial que dificultaria sobremaneira a redução da inflação. Não somente os preços seriam rígidos, mas também os próprios níveis de inflação, reproduzindo a inflação passada total ou parcialmente na inflação corrente. Tal situação levaria a que o controle do processo inflacionário exigisse a manutenção de taxas reais de juros também particularmente elevadas.

A dificuldade introduzida pela relevância do componente inercial da inflação pode ser vista ao considerar a modificação na seguinte relação, a qual consiste em um tipo de curva de Phillips Novo-Keynesiana bem conhecida (Alves; Aerosa, 2005) a qual tem caracterizado o approach padrão que busca captar os principais elementos que interferem na evolução do processo inflacionário. Sem a ocorrência do componente inercial, a inflação $\left(\pi_{\mathrm{t}}\right)$ seria determinada (Barbosa, 2004b) por:

$$
\pi_{t}=\varphi\left(y_{t}-y_{t}^{*}\right)+\gamma E_{t} \pi_{t+1}+\mu_{t}
$$

em que $\left(y_{t}-y_{t}^{*}\right)$ é o hiato do produto, $E \pi_{t+1}$ é a expectativa de inflação para o período seguinte, $\mu_{t}$ é um choque aleatório, e $\varphi$ e $\gamma$ são parâmetros indicando o peso relativo de cada componente. Ao incorporar a esta relação desenhada de forma totalmente forward-looking um componente inercial, indicando que parte dos preços na economia são reajustados com base na inflação passada, teríamos, seguindo uma derivação próxima à realizada por Woodford (2003), que:

$$
\pi_{t}=\lambda \pi_{t-1}+\varphi\left(y_{t}-y_{t}^{*}\right)+\gamma E_{t} \pi_{t+1}+\mu_{t}
$$

onde $0 \leq \lambda \leq 1$ representa a parcela dos preços reajustados pela inflação passada; quanto maior o $\lambda$, mais importante será o componente de inércia na determinação da inflação. Assim, nos modelos incluindo este tipo de relação, a inflação corrente seria função da inflação passada, de um componente relativo ao ajustamento na demanda representado pelo hiato do produto, das expectativas de inflação no período seguinte, além dos choques aleatórios.

A partir desta caracterização, o sucesso do processo desinflacionário requereria a ocorrência de alterações seja no componente relativo à demanda, no componente das expectativas, ou em ambos, de forma a atuar sobre a inflação corrente, reduzindo-a. Este efeito é normalmente alcançado através da elevação das taxas reais de juros, as quais são relacionadas nestes modelos negativamente ao hiato do produto (como veremos no próximo capítulo) por uma 
curva IS tradicional; assim, ao aumentar estas taxas e mantê-las em níveis elevados, conter-seia a demanda agregada e o hiato do produto seria reduzido, impactando diretamente este componente da inflação. Ao mesmo tempo, a perspectiva de manutenção desta política levaria a que as expectativas de inflação também fossem reduzidas, alcançando assim o resultado antiinflacionário perseguido.

Este processo é tanto mais difícil quanto mais elevado for o componente inercial da inflação, uma vez que as alterações na taxa real de juros não provocam nenhum efeito sobre tal componente; assim, nesta situação a elevação nesta taxa deveria ser maior do que a que seria necessária se a primeira relação acima apresentada - em que a inércia não se encontra presente - fosse a correta, já que neste caso o efeito sobre os outros dois componentes da inflação deve ser suficiente para compensar essa inércia e reduzir a inflação.

Nesta lógica, o processo desinflacionário implementado em países como o Brasil, cuja inflação estaria caracterizada pela presença de um importante componente inercial, seria particularmente entremeado por dificuldades e implicaria em elevados custos em termos de produto, uma vez que necessitaria a manutenção de altas taxas de juros para, por um lado, reduzir a inflação corrente como explicado acima, e, pelo outro, para reduzir a importância desse componente inercial, eliminando da memória dos formadores de preços as práticas e rotinas de indexação automática adotadas de forma generalizada e solidamente enraizadas nos comportamentos moldados ao longo de décadas, de modo a que a inflação passada passasse a ter menor importância como determinante da inflação corrente. Tal objetivo seria alcançado pelo funcionamento dos processos de mercado sob condições próximas ou efetivas de recessão, as quais seriam decorrência da manutenção de elevadas taxas reais de juros durante longos períodos; tal situação acabaria por impor aos agentes econômicos o abandono daquelas práticas que caracterizavam a dinâmica inercial dos preços vigente até então, quebrando-a.

Assim, evidencia-se a relação proposta entre o caráter inercial da inflação e a necessidade da imposição de elevadas taxas reais de juro, as quais somente poderiam ser reduzidas de forma gradual (Barbosa, 2004a), conforme o componente inercial fosse reduzido.

Para aceitar esta explicação, entretanto, é necessário verificar se a caracterização da inflação brasileira como contendo um importante componente inercial é efetivamente válida. Embora restem poucas dúvidas quanto à correção desta hipótese para os períodos anteriores à 
estabilização monetária e inclusive durante o período inicial durante o qual esta se verificou, a permanência dessa característica ao longo dos últimos anos não resulta tão evidente, suscitando dúvidas a esse respeito. Discutiremos a seguir algumas explicações que têm sido normalmente colocadas de forma a justificar a persistência do caráter inercial da inflação brasileira, assim como alguns estudos que têm tentado verificar empiricamente a continuidade de sua relevância prática.

Durante os primeiros anos do programa de estabilização, tal componente inercial ainda teria sido decorrente do fato de que a prática historicamente generalizada por parte dos formadores de preço de indexação automática ainda não teria sido totalmente ou mesmo suficientemente reduzida. Este comportamento provocava a propagação da inflação passada na inflação corrente, e fazia com que qualquer choque exógeno tendesse a elevar o patamar inflacionário. Mais recentemente, o fator que mais tem sido evocado para explicar a inércia inflacionária é o comportamento particular dos preços administrados, em sua maioria relativos a serviços públicos administrados por empresas privadas, preços que respondem a aproximadamente $30 \%$ da composição do IPCA, e cuja variação tem se mantido, desde 1996, sistematicamente acima da verificada para o índice total, tendência somente revertida muito recentemente, no segundo semestre de 2006, conforme podemos ver no seguinte gráfico:

Gráfico 5

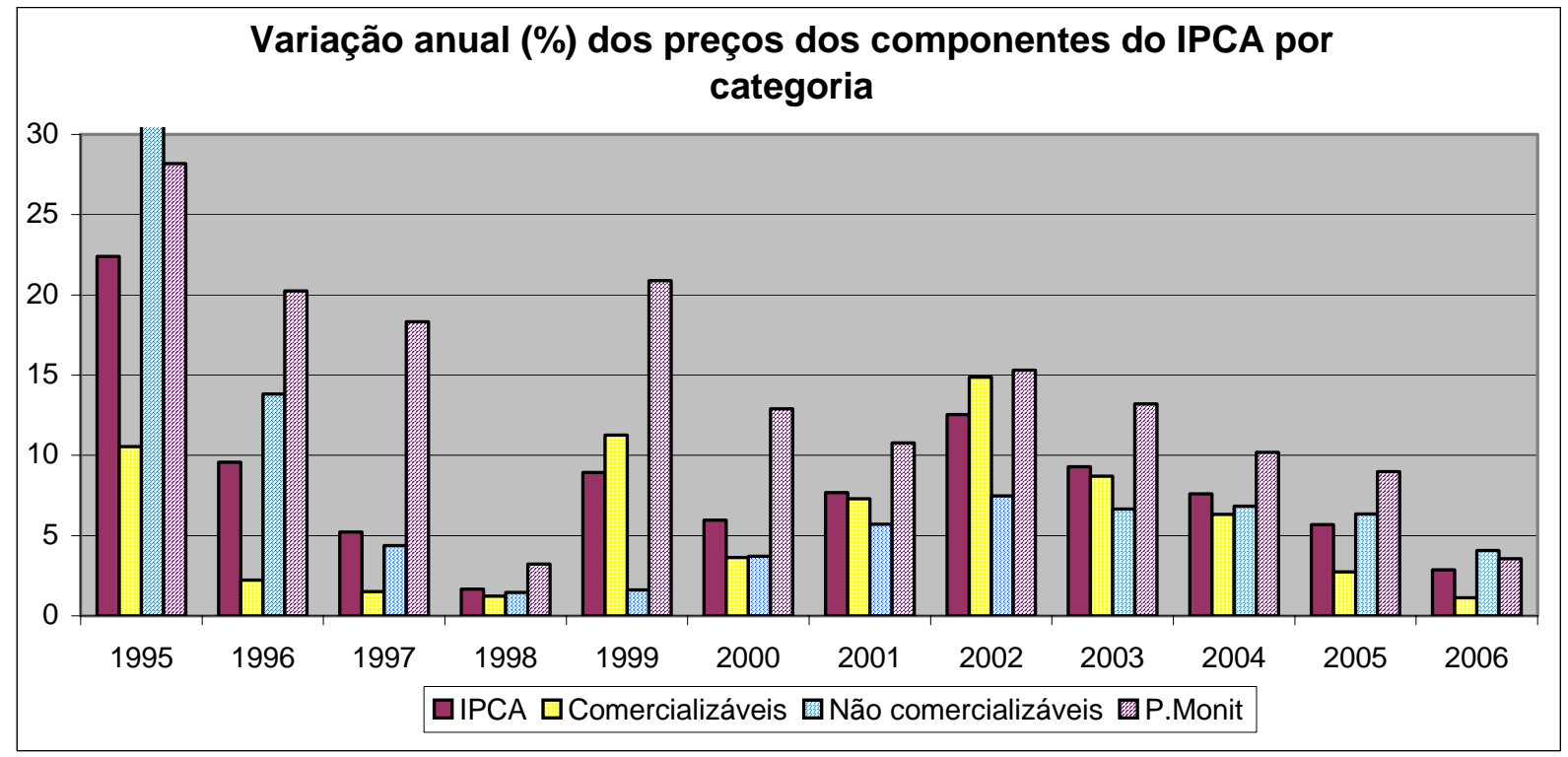

fonte: IBGE

Nota-se aqui que os preços administrados foram efetivamente os que mais se elevaram em todos os anos (com exceção de 1995 e 2006, anos nos quais os preços dos produtos não- 
comercializáveis aumentaram mais) transcorridos desde a estabilização monetária, sendo que, em vários desses anos, o diferencial entre o aumento desses preços e o sofrido pelos bens e serviços comercializáveis e não-comercializáveis foi especialmente importante.

Esta dinâmica própria dos preços administrados se deve fundamentalmente a características particulares dos contratos firmados durante o processo de privatização das concessões de serviços públicos ocorrido principalmente na segunda metade da década de 1990; tais contratos procuraram assegurar às novas empresas prestatárias uma remuneração elevada, através da garantia de reajuste anual de suas tarifas com base nos índices gerais de preços, os IGP's, do ano anterior, institucionalizando um comportamento fundamentalmente do tipo backward-looking em relação aos preços de um setor importante da economia, realimentando assim a inflação passada na inflação corrente. Por outro lado, tais índices possuem em sua composição forte peso dos preços por atacado (IPA's), os quais, por sua vez, são fortemente dominados pelos preços de commodities e de bens semi-manufaturados, que sofrem de elevada volatilidade de preços, os quais normalmente são cotados em moeda estrangeira, acentuando por isso sua sensibilidade a choques de oferta e a flutuações do câmbio. Enquanto normalmente esperaríamos que uma vez ultrapassados os choques, os preços voltassem a se reajustar para baixo, fazendo com que seu impacto fosse apenas temporário, ou, no caso de serem estruturais, os impactos permanecessem setorialmente localizados, no caso brasileiro, a ocorrência de tais choques, ao levar a variações nos índices de preços provoca, em virtude justamente das cláusulas de indexação válidas nos contratos de serviços públicos, a propagação no tempo de seus efeitos nos preços. Dessa forma, não somente os preços administrados seriam responsáveis pelo comportamento inercial da inflação dado seu comportamento backward-looking, como também tornariam sua evolução especialmente vulnerável a choques exógenos de oferta e a variações no câmbio (Farhi, 2005).

Além dos preços administrados, outro componente, que como vimos no gráfico acima já havia influenciado de forma importante os níveis de inflação no início do processo de estabilização, e que pode ter seus reajustes determinados em boa medida seguindo uma lógica backwardlooking, referir-se-ia o comportamento dos preços de bens não-comercializáveis, basicamente serviços. Este tipo de bem corresponde também a pouco mais de $30 \%$ da composição do IPCA e assumiria, com a diminuição do ritmo de aumento dos preços administrados verificada a partir de 2006, um papel fundamental na determinação dos níveis de inflação 
(Lameiras; Giambiagi, 2006), além de promover certa inércia em seu comportamento, dada a maior rigidez nos reajustes de seus preços.

Após discutir os fatores acima, é interessante verificar os resultados que têm sido obtidos em trabalhos que procuraram verificar a permanência do caráter inercial da inflação no Brasil. Nesse sentido, o estudo de Minella (2001) com vetores autorregressivos (VAR) usando dados entre 1975 e 2000, verifica a eventual mudança na dinâmica da inflação com o início do programa desinflacionário em 1994, testando a resposta da inflação a seus próprios choques passados, e encontra evidências de uma sensível redução no grau de persistência da inflação percebida desde a estabilização, apontando como uma das causas o forte declínio na utilização de mecanismos de indexação. Já o estudo posterior de Minella et al (2003), procura verificar se não teria ocorrido uma mudança na dinâmica da inflação após a adoção do regime de Metas de Inflação, uma vez que, segundo os autores, nesse regime a parcela de formadores de preços atuando de forma backward-looking seria menor, o que também ocorreria com a importância da inflação passada nos ajustes de preços de um modo geral, reduzindo assim a inércia da inflação. Usando dados entre 1995 e 2002, os autores efetivamente encontram evidências de que os coeficientes de persistência da inflação teriam se reduzido fortemente desde a adoção do novo regime. Por outro lado, no estudo de Cerisola e Gelos (2005), apesar de reconhecer-se a contribuição dos preços administrados sobre a inércia inflacionária, esta é considerada a partir da análise de dados mais recentes como já sendo pequena, tendo a inflação um limitado componente backward-looking, característica dos comportamentos de indexação automática. Finalmente, temos o trabalho de Maia e Cribari Neto (2006), também verificando eventuais mudanças estruturais ocorridas na dinâmica da inflação no Brasil após o lançamento do Plano Real em 2004, usando para isso modelos auto-regressivos quantílicos, os quais permitem a análise de resultados para quantis condicionais e assim, para toda a distribuição condicional da variável resposta. As conclusões a que eles chegam mostram que a dinâmica da inflação desde o programa de estabilização teria apresentado uma distribuição assimétrica, com coeficientes muito baixos de persistência nos quantis inferiores, nos períodos de baixa inflação, e coeficientes mais elevados, próximos à unidade, nos quantis superiores; assim, o fator de inércia da inflação não seria importante em períodos de baixa inflação, tornando-se relevante em momentos em que esta se acelera.

Analisando os resultados obtidos pelos trabalhos acima, podemos concluir que a relevância do componente inercial da inflação brasileira foi significativamente reduzida nos últimos anos a 
partir do programa de estabilização e com a adoção do regime de metas de inflação, não obstante a pressão continuada ao longo dos anos advinda do aumento, seguindo uma lógica decididamente backward-looking, dos preços administrados acima dos demais preços na economia. Tal conclusão, que tende a reduzir a importância do caráter inercial da inflação nas análises e nas ações tomadas como parte da condução da política monetária, parece encontrar concordância em afirmações feitas pelo próprio COPOM, algumas divulgadas inclusive há já um tempo considerável, como por exemplo na ata de sua $53^{\circ}$ reunião, em novembro de 2000 (COPOM/Bacen, 2000), em que se reconhece o baixo grau de inércia embutido na formação dos preços domésticos. Tal conclusão é reafirmada na carta aberta ao Ministro da Fazenda no início de 2004, a qual reconhece que, como resultado das políticas monetária e fiscal adotadas no início do ano (referindo-se a 2003), “ao final do primeiro semestre de 2003 o grau de inércia inflacionária já teria retrocedido para os baixos níveis que vigoravam antes do repique inflacionário observado no último trimestre de 2002.” (Bacen, 2004, pp.3)

Assim, a manutenção de elevados patamares para as taxas reais de juro a despeito da redução verificada no componente inercial da inflação no Brasil, nos leva à conclusão de que dificilmente possamos associar a este fator um papel determinante para explicar a persistência dessas elevadas taxas, como às vezes é sugerido. Embora a política de manutenção de juros altos tenha provavelmente sido um fator importante no processo de redução da inércia inflacionária, especialmente nos primeiros anos de vigência do programa de estabilização e após o repique inflacionário entre o segundo semestre de 2002 e o início de 2003 , uma vez tendo este programa alcançado sucesso na desinflação e o componente de inércia tendo deixado de ser especialmente relevante, conclusão para a qual os trabalhos acima discutidos parecem de fato apontar, a manutenção de elevadas taxas não mais encontraria nesse componente sua justificativa. Tal atitude, entretanto, somente poderia encontrar lugar se, apesar da rejeição de sua relevância empírica - conclusão que, como vimos, tem se tornado recorrente pelo menos desde 2000 - a dinâmica inercial da inflação continuasse presente como elemento importante nas idéias manipuladas pelos formuladores de política, como parece ser o caso se considerarmos, por exemplo, as afirmações feitas em uma data tão recente como junho de 2006, em apresentação diante da Comissão de Assuntos Econômicos do Senado, na qual o Banco Central, de forma contraditória em relação a afirmações contidas em outros documentos por ele divulgados, ainda advertia contra os riscos associados à existência de uma cultura inflacionária no Brasil, e à necessidade de consolidar o quadro de estabilidade de preços (Bacen, 2006). 


\section{Incerteza Jurisdicional e Juros}

Um conjunto de fatores que buscam explicar as elevadas taxas reais de juro vigentes no Brasil que tem ganhado notoriedade nos últimos anos e que analisaremos nesta seção identifica em variáveis relativas ao conceito de incerteza jurisdicional a raiz das elevadas taxas de juros vigentes no Brasil (Arida et al, 2004). O conceito de incerteza jurisdicional parte da constatação de inexistência de um mercado de crédito e de títulos a longo prazo funcionando sob jurisdição brasileira, apesar de tais mercados para credores e devedores brasileiros existirem quando sob jurisdição estrangeira; assim, seria a incerteza jurisdicional - incerteza em relação à execução dos contratos sob a jurisdição brasileira - a razão da inexistência desses mercados de crédito a longo prazo. Assim, o crédito para brasileiros estaria restrito no Brasil ao curto prazo e, no longo prazo, somente em moeda estrangeira e offshore, escapando à jurisdição brasileira.

Esta situação é justificada por uma incerteza de caráter difuso em relação à estabilidade e segurança dos contratos que permearia as decisões tomadas pelos poderes Executivo, Legislativo e Judiciário no país e se manifestaria no viés anti-poupador - levando possíveis poupadores a evitar tornar suas poupanças disponíveis - e anti-emprestador - levando possíveis emprestadores a evitar emprestar no mercado doméstico - e na conotação negativa das figuras sociais associadas ao emprestador de dinheiro. A incerteza jurisdicional estaria inserida num quadro de baixa qualidade institucional em que as instituições existentes permitiriam a manifestação desses vieses e seriam incapazes de garantir a execução dos contratos e o julgamento isento em casos de litígio, o que teria causado ao longo do tempo grandes perdas aos detentores de ativos financeiros.

Os efeitos particularmente significativos que a incerteza institucional teria sobre as taxas reais de juros brasileiras seriam em parte resultado do fato de que esta incerteza estaria associada no Brasil à relativa inconversibilidade da moeda, o que implicaria a criação de um desnecessário prêmio de risco relacionado à conversão, elevando com isto as taxas. Isto ocorreria porque a possibilidade de introdução de controles cambiais por via administrativa traria consigo a possibilidade de o Banco Central suspender ou contingenciar pagamentos ao exterior, criando o risco de default para estes pagamentos, tanto públicos quanto privados. Nesta situação, o prêmio de risco exigido em operações offshore seria mais elevado. Sendo válida a paridade descoberta da taxa de juros, esse aumento no prêmio de risco para 
transações com o exterior levaria ao aumento nas taxas de juro internas. Estes efeitos da inconversibilidade, entretanto, somente se fariam presentes num ambiente em que prevalecesse a incerteza jurisdicional, que teria a precedência na determinação das elevadas taxas de juros; de fato, apenas na presença desta, uma maior convertibilidade tenderia a diminuí-las.

Finalmente, um último ponto importante se refere ao fato de que, na visão dos autores, a intervenção do Governo, seguindo uma interpretação equivocada de que a inexistência de mercados de crédito se deveria a supostas falhas de mercado, ao procurar solucionar essas falhas teria agravado os efeitos da incerteza jurisdicional. As principais atitudes do governo nesse sentido consistiriam na imposição de dificuldades à livre conversibilidade da moeda, elevando os juros ao aumentar o risco de conversão, e de mecanismos de poupança compulsória, do alongamento artificial da maturidade dos investimentos financeiros, e de práticas por parte das empresas estatais de forma a aumentar a poupança e o investimento, ações que, por artificiais do ponto de vista dos mercados, levariam a distorções alocativas.

Além de diretamente impedir a formação de mercados de crédito de longo prazo, a incerteza jurisdicional provocaria as seguintes distorções no comportamento do poupador:

- na ausência de convertibilidade da moeda, elevaria as taxas de curto prazo requeridas pelos poupadores para deixar seus recursos no mercado local;

- reduziria a quantidade total de poupança dado o risco embutido no adiamento do consumo;

- faria com que o poupador apreciasse especialmente a possibilidade de reprogramar a aplicação de sua riqueza financeira, mantendo-a em aplicações de curto prazo, as mais líquidas possíveis;

- induziria poupadores a transferir seus recursos para mercados offshore;

- aumentaria a preferência dos poupadores por formas de alocação da riqueza que não dependam da intermediação financeira.

Estas mudanças se traduziriam na elevação da taxa de juros de equilíbrio, levando ao aumento das taxas reais. De forma contrária, reformas institucionais que diminuíssem a incerteza jurisdicional ou a inconversibilidade da moeda levariam a uma diminuição dessa taxa. 
A hipótese de que um baixo nível de convertibilidade implicaria no aumento do prêmio de risco é contestada por Oreiro et al (2003), que apontam para o fato de que, apesar de ter caminhado ao longo da década de 90 numa direção clara de crescente liberalização da conta capital, não teria se verificado nenhuma tendência de diminuição do risco-país nem das taxas reais de juro domésticas. Os resultados do estudo de regressão realizado pelos autores rejeitam, de fato, a hipótese de existência de uma relação direta entre mudanças nos controles administrativos relacionados à conversibilidade da moeda nacional, e a variação do risco-país. Também não encontram, por meio de um estudo de cointegração, evidências da existência de uma relação de longo prazo entre o prêmio de risco e o nível dos controles de entrada e saída de capitais. Portanto, os autores globalmente rejeitam a relevância empírica da inconversibilidade como elemento relevante para explicar as elevadas taxas de juros.

Por outro lado, buscando comprovar por meio de um estudo empírico a validade da hipótese da incerteza jurisdicional, Gonçalves et al (2005) estimam uma equação em que a taxa real de juros de curto prazo é a variável dependente, e as variáveis explicativas são formadas pela interação de distintas medidas de incerteza jurisdicional com índices de convertibilidade da moeda. Além da hipótese original, as seguintes variantes em que os dois grupos de variáveis interagem são testadas: inconversibilidade afetando diretamente taxas de juros, mesmo sem a ocorrência de incerteza jurisdicional; a não existência de interação entre as variáveis; e a importância preponderante da convertibilidade afetando a taxas de juros, com a incerteza jurisdicional tendo efeito somente nos casos de inconversibilidade.

De forma a comparar informações de vários países que permitam a verificação da hipótese, a estimação é feita com dados em painel obtidos de duas bases distintas, com 199 e 123 países, cada uma usando várias medidas de qualidade institucional. Além disso, são introduzidas duas variáveis de controle, inflação e relação dívida/PIB, eventualmente captando outras fontes mais convencionais de diferenças nas taxas de juros entre países.

Os resultados dos testes, tanto na forma original como em suas variantes, mostram a maioria dos coeficientes de variáveis relacionadas à incerteza jurisdicional como não significativos, e em vários casos com os sinais contrários ao esperado. Quando os controles são adicionados, não só o ajuste das regressões $\left(\mathrm{R}^{2}\right.$ menor que $5 \%$ sem os controles) é significativamente melhorado, como os coeficientes destes controles - inflação e relação dívida/PIB - são significativos, o que mostra, se algo, que estas variáveis são sensivelmente mais capazes de 
explicar as diferenças entre as taxas de juros dos países da amostra do que a incerteza jurisdicional.

Assim, podemos dizer que em geral os resultados obtidos por estes estudos rejeitam a hipótese de Arida, Bacha e Lara Resende, mostrando que, ao contrário do que pretendem os autores, a incerteza jurisdicional, a inconversibilidade da moeda e a interação entre ambas não são capazes de explicar satisfatoriamente as diferenças verificadas entre as taxas reais de juro de curto prazo vigentes em diferentes países. Resta a este conjunto de idéias, à espera de novos estudos que verifiquem sua eventual validade, o comentário de Fraga (2005), para quem a incerteza jurisdicional seria um conceito mais adequado para explicar os spreads que afetam o crédito do que as taxas básicas de juros.

\section{Resultado Fiscal e Juros}

Considera-se normalmente que a influência do resultado obtido pelas contas do Governo sobre as taxas reais de juro se dá fundamentalmente por meio de dois mecanismos distintos, embora relacionados: através de seu efeito sobre a percepção de risco por parte dos agentes, assunto que, nas discussões correntes, tem sido o mais estudado, e que discutiremos de forma detalhada na próxima seção; e através de seu efeito direto sobre a demanda agregada, ponto a ser analisado nesta seção.

Este efeito sobre a demanda é aquele discutido inclusive nos modelos macroeconômicos mais simples apresentados em livros-texto (Dornbusch; Fischer, 1991), usando o instrumental ISLM. Nestes modelos, a variação dos gastos do Governo deveria vir acompanhada, de forma a manter uma situação de equilíbrio, por uma variação em sentido contrário por parte da disponibilidade de recursos para financiá-los. Assim, uma expansão dos gastos do Governo somente seria possível se ocorresse uma diminuição nos gastos privados com investimento o que caracterizaria o efeito de crowding-out -, um aumento na poupança das famílias que elevasse os fundos disponíveis para empréstimo, ou ambos. O novo equilíbrio com maiores gastos do Governo, alcançado após as modificações necessárias nos gastos privados e na disponibilidade de poupança para empréstimo, normalmente requereria a elevação das taxas de juros, estabelecendo uma relação positiva entre estas taxas e os gastos governamentais. $\mathrm{O}$ efeito contrário verificar-se-ia quando os gastos governamentais fossem reduzidos. Dada a 
importância relativa, normalmente considerável, deste tipo de gasto sobre a composição da demanda agregada, o impacto de alterações no seu patamar sobre as taxas de juro poderia inclusive ser relevante.

É necessário assinalar, contudo, que esta dinâmica refere-se especialmente às taxas de juros de prazo mais longo, que não são as taxas nas quais estamos diretamente interessados neste trabalho. Entretanto, num regime de metas de inflação como o adotado pelo Brasil desde meados de 1999, esta distinção torna-se menos importante, uma vez que as taxas de juros de curto prazo são manipuladas pelo Bacen principalmente de forma a que, e justamente graças a seus efeitos esperados sobre a determinação das taxas de prazo mais longo - para o que normalmente é necessário considerar a existência de uma estrutura a termo das taxas de juros (Brito et al, 2004) relativamente estável -, possam funcionar como instrumento adequado no controle da demanda agregada, reduzindo com isso pressões inflacionárias cujas origens se encontrem nessa própria demanda, considerada nessa situação como sendo excessiva. E nesta tentativa de controle da demanda agregada, a contenção dos gastos do Governo aparece como elemento fundamental já que, quanto menores fossem estes gastos - os quais são, a princípio, insensíveis a variações nas taxas de juros -, maior seria a importância relativa dos demais componentes da demanda agregada, estes sim sensíveis às taxas de juros, e menor, portanto o impacto nestas taxas necessário para controlar a inflação; o efeito contrário se daria no caso dos gastos serem elevados. Assim, a relação entre o gasto público e o aumento das taxas de juros influenciaria não somente as taxas de longo, mas também as de curto prazo.

Os efeitos objetivos sobre a taxa real de juros provocados pela pressão dos gastos do Governo sobre a demanda agregada no caso desta hipótese ser efetivamente válida, se confundem com o impacto dos gastos governamentais sobre a percepção de risco em relação aos títulos da dívida pública e os efeitos deste risco sobre aquelas taxas, relação que será discutida na próxima seção. Como os efeitos do gasto público sobre as taxas de juro serão mais adiante discutidos a partir da evidência empírica, nesta seção que agora termina não levaremos a cabo tal discussão. Entretanto, para referência futura, podemos apontar para o fato de que tal situação em que a demanda teria alcançado níveis próximos ao limite imposto pela capacidade de oferta, onde qualquer expansão nos gastos públicos implicaria num deslocamento dos gastos privados obtido através do aumento da taxa real de juros, teria se restringido desde a estabilização monetária no Brasil a pouquíssimos episódios e de curta duração. Isto apontaria para a provável baixa relevância empírica do caminho pelo qual a política fiscal impactaria as 
taxas de juro discutido nesta seção Apesar disso, a idéia de que os gastos públicos seriam uma fonte de pressão importante sobre a demanda agregada vista como normalmente aquecida tem sistematicamente permeado as discussões em torno da explicação dos motivos para a manutenção de elevadas taxas reais de juro.

\section{Resultado Fiscal, Risco e Juros}

Entretanto, a maioria dos fatores que mais freqüente e extensamente tem sido apontados como afetando a relação entre as variáveis fiscais e a determinação das taxas de juro se referem aos efeitos daquelas sobre a percepção de risco por parte dos participantes do mercado de títulos de dívida, assumindo a existência por sua vez de uma relação importante entre o nível de risco e as taxas de juro. Assim, dependendo da situação daquelas variáveis fiscais, o risco percebido seria mais ou menos elevado, e maior ou menor seria o prêmio que deveria em conseqüência ser pago, afetando desta forma as taxas de juro exigidas para o carregamento dos títulos de dívida. Neste encadeamento entre as considerações relativas às variáveis fiscais e as taxas de juros praticadas, notam-se dois elos claramente definidos, entre as variáveis fiscais e as considerações de risco, e destas às taxas de juro, os quais serão discutidos a seguir.

\section{Situação fiscal e risco}

As relações entre a posição fiscal e a percepção de risco mais frequentemente sugeridas podem ser encontradas ao analisar os principais tipos de risco normalmente considerados (rotineiramente agrupados no que se denomina, genericamente, de risco-país):

- Possibilidade de default da dívida pública: é principalmente em relação a este tipo de risco que as variáveis fiscais teriam seu maior impacto. Tal risco está relacionado à existência de uma probabilidade não-nula de que os pagamentos de juros e amortizações relacionados à dívida sejam interrompidos total ou parcialmente, e de forma unilateral, pelo devedor. A probabilidade de este default ocorrer seria função principalmente (mas não somente; o componente de risco político - a decisão de default seria uma opção de política, e não decorreria necessariamente de problemas relativos à solvabilidade - é um elemento normalmente pertinente neste tipo de análise) de considerações relativas à solvabilidade do 
setor público, as quais por sua vez dependeriam basicamente de variáveis associadas à posição fiscal: o tamanho da dívida (considerada em sua proporção em relação ao PIB); os custos - basicamente a taxa de juros - e prazos associados à sua rolagem - os quais variam, entre outros fatores, em função das condições de liquidez nos mercados doméstico e internacional -; e a situação corrente e esperada das contas do Governo, medida principalmente pelo déficit/superávit fiscal primário - portanto sem considerar os gastos com os encargos da dívida - em relação ao PIB, variável que indica a capacidade do Governo em obter os recursos necessários para honrar seus compromissos relativos à dívida, de forma a reduzi-la ou manter seu tamanho estável; finalmente, uma variável relevante, embora dificilmente quantificável, se refere à capacidade que o Governo disporia de elevar receitas e diminuir despesas quando fosse necessário de forma a honrar seus compromissos. Quanto menor o tamanho da dívida, menor o seu custo e maiores seus prazos, e quanto mais elevado for o superávit fiscal primário, menor deveria ser, a princípio, o risco associado ao default da dívida. Este risco de default aqui abordado afetaria todos os títulos de dívida pública, estejam eles definidos em moeda nacional ou estrangeira, lançados no país ou no exterior, e sejam seus rendimentos pré ou pós-fixados.

- Desvalorização cambial não esperada (risco de câmbio) e risco de default externo: mesmo que o Governo seja solvente internamente, pode-se dar a situação de que o país eventualmente não disponha de reservas em moeda estrangeira suficientemente elevadas para honrar seus compromissos externos em um determinado momento, sejam tais compromissos referentes aos encargos da dívida, tanto pública quanto privada, ou sejam relativos à cobertura de déficits nas contas externas de um modo geral. Nessa situação de escassez de divisas e insolvência externa, a moeda local pode sofrer uma desvalorização cambial que, quando não esperada, leva os detentores dos títulos de dívida fixados em moeda nacional a perdas, eventualmente significativas, quando avaliados em moeda estrangeira. Por outro lado, problemas de solvência em divisas, como os acima apontados, ou decisões políticas, podem levar à imposição de controles e barreiras sobre a mobilidade de capital - inclusive a suspensão parcial ou total de pagamentos - e de uma legislação discriminatória em relação ao país de origem desse capital (Sant'Anna, 2003), difícultando ocasionando perdas associadas à recuperação do principal e dos rendimentos relativos a investimentos externos realizados no país. 
- Aceleração inflacionária não esperada (risco de inflação): com a ocorrência deste fenômeno, seja ele causado por choques exógenos de preços de commodities ou outros, ou pela tentativa do Governo de, diante da existência de déficits fiscais importantes, financiar-se mediante a emissão de moeda levando com isso a pressões sobre a demanda agregada, os rendimentos dos títulos de dívida pré-fixados se veriam corroídos de acordo com o tamanho da surpresa na inflação. A surpresa inflacionária pode por sua vez vir acompanhada ou não por uma desvalorização cambial, caso no qual os riscos de câmbio e inflação se somariam.

Ao analisar estes tipos de risco, notamos que a instância fiscal afetaria, como dissemos, principalmente e de forma direta a possibilidade de default, mas também, indiretamente, os riscos de câmbio e de inflação, afetando portanto globalmente o risco-país. Nesta concepção, enquanto a situação fiscal apontar para a persistência de déficits ou mesmo superávits primários que não forem suficientemente elevados de forma a permitir a redução ou pelo menos a estabilização do tamanho da dívida, o risco-país permaneceria em níveis elevados e elevados prêmios continuariam a ser exigidos, resultando em elevadas taxas de juros.

A aceitação da validade da relação acima discutida entre as variáveis fiscais e o risco-país, apesar de logicamente consistente, depende em boa medida de sua verificação empírica, o que é feito, por exemplo, no trabalho de Leichsering (2004), que para isso utiliza um modelo VAR com dados para o Brasil em que se avaliam os choques em cada uma das variáveis por meio de funções de resposta ao impulso generalizadas. O trabalho encontra que, efetivamente, após a desvalorização cambial em 1999, o risco-país medido para o Brasil usando o índice $\mathrm{EMBI}^{+}$ ajustado de forma levar em consideração variações na aversão ao risco no mercado internacional, tem tido como determinantes principais as variáveis fiscais, especialmente as relações dívida/PIB e dívida externa/dívida total, além do nível das próprias taxas nominais internas de juro - uma explicação para esta possibilidade será discutida logo a seguir.

Entretanto, os resultados encontrados por Yuki (2004) em trabalho com objetivo semelhante mas usando metodologia distinta, incluindo novas variáveis e utilizando dados em painel para vários países, impõem algumas restrições a esta conclusão. Assim, procurando os determinantes do risco-país, medido neste caso pelos ratings de risco divulgados semestralmente pela revista Institutional Investor, calculados para 145 países utilizando informações fornecidas por bancos credores internacionais, este trabalho encontra que, ao lado dos fatores relacionados a variáveis macroeconômicas fundamentais - na verdade, 
apontando como significativas apenas as relações resultado primário/PIB e conta corrente/PIB -, uma variável dummy indicando se o país passou desde 1980 por algum episódio de inadimplência em relação a seus compromissos sobre a dívida, e outra indicando se o país estaria localizado na América do Sul, não somente têm, em varias configurações testadas, seus coeficientes sempre altamente significativos, como também seus valores são comparáveis aos das variáveis mais convencionais - que continuariam, contudo importantes; além disso, sua inclusão aumenta decisivamente o coeficiente de determinação da regressão. Assim, este trabalho acaba retirando parte significativa da importância normalmente atribuída às considerações relacionadas à situação fiscal na definição do risco-país, ao introduzir outras variáveis - reputação e localização - sobre as quais o governo não tem a menor capacidade de intervir com sua política, como sendo fundamentais na determinação do risco.

Dúvidas quanto à existência de uma relação inequívoca e direta entre as variáveis relativas à situação fiscal e a percepção de risco podem também surgir a partir da análise do trabalho de Canuto e Santos (2003) que, embora confirme a importância desse tipo de variáveis, introduz vários fatores macroeconômicos não diretamente relacionados à instância físcal como sendo especialmente relevantes na explicação da classificação de risco outorgada ao país por agências internacionais de avaliação. Tais fatores incluem, notadamente:

- A renda per capita, considerada como bom indicador do nível geral de desenvolvimento econômico e institucional do país, o que seria importante dado que as autoridades de países desenvolvidos com uma longa história de estabilidade econômica e institucional disporiam de melhores instrumentos para administrar dívidas públicas e déficits fiscais elevados, bem como choques econômicos inesperados.

- O desenvolvimento do setor financeiro, em que níveis mais elevados indicariam maiores custos implicados numa moratória, dada a maior parcela da população situada em posição de credora da dívida.

- O grau de abertura comercial e financeira do país em relação ao resto do mundo, que afetaria a disposição a honrar as dívidas, dado que os custos econômicos e financeiros de uma moratória para um país são diretamente proporcionais a seu grau de integração com o exterior (Standard and Poor's, 1998), fato que ocorreria porque o setor privado de uma economia aberta usa intensivamente o mercado financeiro internacional para financiar 
investimentos, exportações e importações. Além disso, onde há uma política de abertura comercial, as indústrias seriam mais competitivas e voltadas para o mercado externo, favorecendo a geração de divisas, e aumentando, por conseguinte, a capacidade de honrar os pagamentos externos. Finalmente, países onde a participação do comércio exterior no PIB é elevada necessitam uma desvalorização cambial de menor proporção para promover um ajuste do balanço de pagamentos, diante de choques externos.

Por outro lado, o trabalho termina por diminuir a importância de qualquer conjunto de fatores, inclusive aqueles associados à posição fiscal, quando analisados de forma independente, salientando "que o poder explicativo [...] se dá em nível do conjunto. Pouco adianta evoluir favoravelmente em apenas um ou poucos entre os indicadores, já que a melhora apenas parcial dos fundamentos macroeconômicos tende a gerar "retornos decrescentes" em termos de ratings." (Canuto; Santos, 2003, p.39)

As dúvidas colocadas, por exemplo, por estes dois trabalhos em relação à importância decisiva das variáveis fiscais na explicação do risco-país certamente apontam para a necessidade de novos estudos que investiguem sua validade empírica. Sem negar a consistência lógica da relação entre as variáveis fiscais e o risco-país, resulta, contudo fundamental verificar a relevância relativa destas variáveis quando comparadas a outros fatores, os principais dos quais foram acima discutidos, que também explicariam as medidas de risco.

\section{Risco e taxas de juro}

As qualificações acima introduzidas em relação à influência das variáveis fiscais sobre os níveis de risco não diminuem, necessariamente, a importância deste risco na determinação das taxas de juros, objetivo último discutido nesta seção. Entretanto, a validade e relevância desta relação também precisam ser discutidas.

A lógica que coloca as considerações de risco no centro da determinação das taxas de juros se apóia implicitamente na validade e estabilidade da teoria da paridade descoberta da taxa de juros (Muinhos et al, 2001), a qual relaciona alterações esperadas na taxa de câmbio com os 
diferenciais verificados entre a taxa de juros doméstica e internacional. Se a paridade descoberta fosse válida, a taxa de juros doméstica $\left(i_{t}\right)$ seria dada por:

$$
i_{t}=i_{t}^{*}+\left(E_{t} e_{t+1}-e_{t}\right)+x_{t}
$$

onde $i_{t}{ }^{*}$ é a taxa de juros internacional, $\left(E_{t} e_{t+1}-e_{t}\right)$ é a variação esperada na taxa de câmbio, e $x_{t}$ é o prêmio de risco. Assim, supondo, por exemplo, que a taxa de câmbio esperada permaneça estável, a taxa nominal de juros no país seria equivalente à taxa internacional, acrescida de um prêmio de risco; se tal situação não se verificasse, teríamos que, ou a expectativa de desvalorização cambial não seria de fato nula, ou existiria uma oportunidade lucrativa de arbitragem entre títulos internos e externos que, ao ser aproveitada, conduziria a taxa doméstica em direção ao equilíbrio previsto pela teoria. Se trabalharmos com taxas reais de juro, quando não houvesse perspectiva de alteração no câmbio, a taxa real interna seria simplesmente igual à taxa internacional mais o prêmio de risco; considerando que a taxa internacional varia a princípio apenas de forma lenta, nota-se o papel fundamental que o prêmio de risco desempenha. Entretanto, é necessário assinalar que a validade empírica desta proposição como forma de explicar e prever satisfatoriamente as taxas de juros e de câmbio tem sido freqüentemente questionada, e mesmo entre seus defensores (Isard, 2006) não existe até o momento uma explicação aceita de forma generalizada que explique a falha da teoria em estudos empíricos.

A despeito de tais questionamentos, estudos para o caso do Brasil tem sistematicamente adotado e eventualmente procurado verificar esta hipótese. Neste segundo sentido, Favero e Giavazzi (2002), por exemplo, ao analisar a evolução das taxas de juro vigentes no Brasil, comparando as taxas efetivamente verificadas com aquelas implícitas na média das taxas Selic esperadas, atribuem os elevados patamares verificados (para títulos com maturidade superior a três meses; as taxas mais curtas seriam diretamente função da regra de política monetária seguida pelo Bacen) inteiramente ao prêmio de risco, que seria particularmente elevado no Brasil. Os trabalhos de Loureiro e Barbosa (2003) e Garcia (2002), por sua vez, também apontam para a relação fundamental entre o prêmio de risco e as taxas de juro.

Este prêmio de risco, devido como vimos não somente às variáveis relacionadas à instância fiscal mas também a outros fatores, não afetaria apenas a taxa de juros dos títulos de dívida 
pública, mas, no caso particular do Brasil, impactaria diretamente, através de um efeito de "contágio" (Barbosa, 2006), a taxa paga pelas reservas monetárias do Bacen. De fato, em função da possibilidade que foi historicamente outorgada ao Bacen no Brasil de gerenciar títulos nominalmente emitidos pelo Tesouro e, posteriormente, de emitir seus próprios títulos, usados ao invés das reservas monetárias como lastro nas operações do sistema bancário, e do fato de que, até hoje, boa parte dos títulos públicos apresentem prazo extremamente curto e compartilhem com os mercados monetários a mesma taxa de remuneração (Selic), a qual é definida como meta operacional pelo Bacen, os títulos do governo e as reservas monetárias se tornaram substitutos perfeitos como reserva de valor. Nessa situação, o equilíbrio nos mercados monetário e de títulos exige que ambos apresentem rendimentos compatíveis, introjetando assim o prêmio de risco pago pelos títulos públicos nas reservas monetárias.

Entretanto, a relação direta aqui comentada entre o prêmio de risco e as taxas de juros, tanto dos títulos da dívida quanto das reservas monetárias, não é somente questionada em função das críticas colocadas em relação à validade empírica da paridade descoberta da taxa de juros, mas é teórica e empiricamente relativizada ao ser apontada a possibilidade de que seu sentido de causalidade seja invertido ao verificar-se a ocorrência de uma situação denominada na literatura como de dominância fiscal. Esta situação, discutida em trabalhos como o dos mesmos Favero e Giavazzi (2004) e Carneiro e Wu (2005), refere-se à possibilidade de que a política monetária, numa situação de elevado endividamento, ao recomendar a elevação da taxa de juros perca sua efetividade. Isto ocorreria porque a elevação dos juros, quando levada a cabo sem um aumento correspondente do superávit primário, tornaria a posição fiscal do Governo mais frágil, provocaria a expansão da dívida pública em função da realimentação financeira e a deixaria mais dificilmente sustentável, o que acabaria provocando a elevação da percepção de risco de default por parte dos investidores e assim dos spreads que eles exigem, conduzindo por sua vez a novos aumentos nos juros e fechando o círculo vicioso. Tal dinâmica estabeleceria uma relação direta entre a elevação da taxa de juros e o risco-país, no sentido contrário ao originalmente proposto.

A ineficiência da política monetária ficaria aqui caracterizada quando consideramos que a tentativa do controle da inflação, a qual teria inicialmente motivado a elevação da taxa de juros, ao provocar a elevação mencionada na percepção de risco, tenderia a provocar a saída de capitais conduzindo ao aparecimento de pressões no sentido da desvalorização cambial, as quais por usa vez elevariam o preço dos produtos importados e fariam com que as 
expectativas de inflação fossem revistas para cima, e eventualmente elevaria a própria inflação, de forma justamente oposta ao que inicialmente a política intencionava fazer. Nesta situação, a política monetária não é efetiva e a política fiscal condiciona os resultados da política antiinflacionária, eventualmente impedindo, por exemplo, a adoção de um sistema de metas de inflação. Num contexto no qual o aumento da taxa de juros, em vez de tornar a dívida do governo mais atrativa e conduzir a uma apreciação cambial, reduz sua atratividade e gera uma tendência à depreciação, a política fiscal, e não a monetária, seria o instrumento adequado para combater a inflação (Blanchard, 2004).

Estudo de Zoli (2005) encontra indícios que sugerem a caracterização de uma situação de dominância fiscal no Brasil na década de 1990 e início de 2000, embora evidência mais fortes existam apenas para o período entre 2002 e o início de 2004. Resultados compatíveis são encontrados nos trabalhos de Favero e Giavazzi e de Blanchard acima citados, assim como no de Nishijima (2005), que encontram evidências que restringem a ocorrência de uma possível situação de dominância no Brasil apenas durante o relativamente breve período entre fins de 2002 e início de 2003, durante o período pré-eleitoral e de transição a um novo governo. Tal situação não teria perdurado uma vez que, segundo Favero e Giavazzi, bastou a sinalização no início do novo governo reafirmando seu compromisso com uma condução austera da política fiscal através do anúncio de uma regra de política mais rígida, para "trazer a economia de volta a suas condições normais, e rapidamente reduzir o spread do EMBI, estabilizar a taxa de câmbio e, através dessas duas variáveis, as expectativas de inflação, a própria inflação, e a dinâmica da dívida pública." (Favero; Giavazzi, 2004, p.19) Entretanto, apesar da suposta ocorrência deste círculo virtuoso, juntamente com o festejado anúncio quanto à política fiscal, as taxas reais de juro foram fortemente elevadas, alcançando valores de mais de $16 \%$ ao ano. Ou seja, esta ocasião, diferentemente do pretendido pelos autores, mostra um episódio no qual o aumento da rigidez da política fiscal, apesar de aparentemente ter contribuído na redução da percepção de risco, não teria levado à redução das taxas de juros mas, pelo contrário, veio acompanhada por sua elevação, sustentada ainda por vários meses. Tal situação evidencia a necessidade de relativizar a importância das considerações de risco na determinação da taxa de juros.

Apesar de ter sua validade empírica fortemente contestada no que se refere à sua capacidade de explicar de forma adequada os movimentos verificados nas taxas de juros, o prêmio de risco continua a ser extensamente utilizado em modelos tanto teóricos quanto empíricos como 
elemento importante na determinação da taxa de juros. Sem negar a possível significância da percepção de risco sobre a determinação das taxas de juro, relação que efetivamente se apresenta como teoricamente consistente, considerando que não foi possível até o momento confirmar sua relevância empírica, o que pode ocorrer em função da própria volatilidade da percepção de risco, fato que dificultaria o estabelecimento de relações minimamente estáveis e que pudessem ser captadas através dos procedimentos normais de estimação, deve-se ter em mente que as conclusões obtidas a partir de modelos cujos resultados sejam particularmente sensíveis à maneira em que as considerações de risco foram incluídas devem ser adotadas de forma especialmente cautelosa.

\section{Situação fiscal e juros}

O fato de que tanto a relação entre a situação fiscal e a percepção de risco, quanto a relação entre este risco e as taxas de juro estejam, como vimos acima, sujeitas a uma variedade importante de críticas, especialmente no que se refere à sua validade empírica, não tem de forma alguma impedido que as particularmente elevadas taxas de juro vigentes no Brasil sejam normalmente explicadas como decorrendo de forma direta de uma percepção de risco também especialmente elevada, a qual teria origem fundamentalmente na suposta fragilidade das contas públicas, o que se somaria ao efeito direto sobre as taxas de juros decorrente da pressão dos gastos do Governo sobre a demanda agregada, discutido na seção anterior; assim, “[...] mais dívida é sinônimo de juros reais mais elevados”. (Troster, 2006) Tal explicação continua sendo provavelmente a mais difundida - ao lado ou como complemento àquela que justifica as taxas de juro como resultando de forma praticamente automática das necessidades impostas pela condução da política monetária antiinflacionária seguida pelo Bacen -, e isto apesar dessas críticas e das fortes evidências, para o caso brasileiro, que por um lado mostram uma marcada melhora na situação fiscal verificada a partir de 1999, representada pela geração continuada de superávits primários, os quais têm se sustentado ao longo de um período já extenso de oito anos e que inclusive aumentaram de patamar a partir de 2003, e que pelo outro apontam para uma elevada volatilidade do prêmio de risco, em todo caso muito superior à volatilidade das taxas de juro, constatação que normalmente deveria provocar dúvidas, se não quanto à conveniência da inclusão do risco como elemento relevante na explicação destas taxas, pelo menos em relação a seu caráter determinante. 
Esta concepção, que coloca a situação fiscal no centro das justificativas para as elevadas taxas de juro, aparece normalmente em comunicados difundidos pelo próprio COPOM, como por exemplo, o que consta na primeira ata de reunião disponível para acesso público na Internet, de março de 1998, que relaciona explicitamente a taxa de juros à situação fiscal vigente (COPOM/Bacen, 1998), ou, nove anos mais tarde, com outra diretoria e sob um novo governo, na última ata divulgada, referente à reunião ocorrida em janeiro de 2007, que condiciona a queda dos juros reais excepcionalmente elevados à queda na percepção de risco (COPOM/Bacen, 2007) a qual, embora ainda elevada para padrões internacionais, encontra-se nos menores patamares já observados desde que medições mais sistemáticas do nível percebido de risco começaram a ser realizadas.

Assim, diante da extensão e freqüência com que este tipo de explicação é difundida, e de seu impacto direto na condução da política monetária, resulta particularmente apropriado verificar se os resultados empíricos a partir dela obtidos aderem satisfatoriamente à realidade.

Nesse sentido, testando os coeficientes de correlação entre a relação dívida/PIB como proxie para a situação fiscal e as taxas reais de juros para vários países em desenvolvimento com dados entre 1995 e 2004, Muinhos e Nakane (2006) não encontram evidências suficientes que comprovem a correlação positiva esperada entre as duas variáveis, com a exceção de alguns países, entre os quais o Brasil. Entretanto, constatam que, apesar dessa correlação, mesmo para o caso do Brasil não é possível rejeitar a não-causalidade de Granger entre a relação dívida/PIB e as taxas de juros, reforçando as dúvidas quanto à correção desta hipótese.

Por outro lado, ao realizar uma estimação SUR com dados em painel para 12 países entre 1995 e 2003, colocando os juros reais como variável dependente e controlando para a primeira diferença da relação dívida/PIB, para o nível de reservas e a taxa de câmbio, o estudo encontra um coeficiente negativo para o primeiro controle, indicando que um aumento na relação dívida/PIB levaria a juros menores, o que certamente não é esperado, além de coeficientes não significativos para os outros controles. Por outro lado, o efeito fixo estimado é significativo para quase todos os países, sendo que o valor para o Brasil é o segundo maior da amostra (atrás apenas do Peru), o que parece indicar que fatores outros que aqueles captados pelas variáveis utilizadas, constantes no tempo para cada país, possuem importância significativa, especialmente no caso do Brasil, na explicação das taxas de juro verificadas. Ao substituir na estimação a relação dívida/PIB pelo prêmio de risco indicado pelo índice EMBI, 
que não reflete apenas essa relação mas também vários parâmetros que interferem na formação da percepção de risco de um país, os resultados obtidos mostram um coeficiente significativo e positivo, como seria normalmente esperado, para essa variável de controle, enquanto continua mostrando a maioria dos efeitos fixos também como significativos, embora com valores menores; dentre estes, o efeito fixo estimado para o Brasil continua sendo o segundo mais elevado da amostra.

Uma terceira análise apresentada no mesmo trabalho relacionando o risco às taxas reais de juro é realizada verificando-se a correlação existente entre estas taxas e a classificação de risco divulgada pela agência Moody’s para 16 países, o que se obtém ao visualizar um gráfico no qual se incluem ambas variáveis; aqui, a relação juros-risco apresenta, como poderíamos esperar, uma correlação negativa (embora fraca) para o conjunto de países da amostra; entretanto, quando procuramos a observação relativa ao caso do Brasil (assim como também para o Peru) vemos que ela se situa distante da curva ajustada, evidenciando a insuficiência do risco avaliado desta maneira para explicar a particularidade das taxas brasileiras.

Assim, ao analisar os resultados alcançados por este trabalho não conseguimos encontrar evidências da existência de uma relação clara entre taxas reais de juro e a relação dívida/PIB, embora encontremos tal relação quando a variável utilizada é o EMBI, indicando que talvez medidas como esta que procuram aferir de forma direta a percepção de risco por parte dos agentes sejam mais adequadas para explicar essas taxas. Entretanto, mesmo esta conclusão deve ser relativizada ao considerarmos a significância e os elevados valores encontrados para os efeitos fixos, o que indica que as variáveis incluídas na estimação não teriam conseguido explicar parcela significativa das diferenças encontradas nas taxas reais de juro válidas nos diferentes países da amostra. Por outro lado, evidências contrárias, neste caso relacionadas às classificações de risco, também são encontradas se considerarmos a rejeição, para o caso do Brasil, de uma possível correlação entre a taxa de juros e a classificação de risco da Moody’s.

Na próxima seção, buscaremos complementar e eventualmente confirmar, a partir do exame de alguns estudos originais simples, os resultados encontrados no trabalho de Muinhos e Nakane no que se refere às evidências que comprovem (ou rejeitem) a relação entre as taxas reais de juro e as distintas medidas normalmente sugeridas como representando direta ou indiretamente a percepção de risco associado a cada país. 


\section{Uma contribuição empírica}

A primeira questão que deve ser discutida ao procurar avaliar a relação entre o risco e as taxas de juro está relacionada à maneira como devemos considerar esse risco. Em relação a isso, podemos usar as duas seguintes abordagens:

- Indireta: se aceitarmos que algumas variáveis, já discutidas na seção anterior, teriam uma relação direta com a percepção de risco, a qual seria por sua vez um elemento fundamental na determinação das taxas de juros, deveríamos ser capazes de identificar relações estáveis entre diferenças nessas variáveis, que apesar de não serem em si uma medida direta de risco são normalmente consideradas como estando a ele associadas, e as taxas de juros praticadas. Tais variáveis referem-se fundamentalmente a dois conjuntos distintos de fatores: por um lado, temos as variáveis extensamente evocadas relacionadas às finanças públicas, principalmente o déficit/superávit primário, o volume da dívida, e suas condições de rolagem, variáveis que afetariam, como discutimos acima, principalmente o risco percebido de default da dívida pública, tanto interna quanto externa, além do risco de desvalorização da dívida pós-fixada provocado pela aceleração inflacionária. Um segundo conjunto de variáveis também normalmente considerado que interfeririam na percepção de risco engloba aquelas referentes à capacidade do país em obter divisas de forma a poder honrar os pagamentos externos, como por exemplo, as medidas relacionadas ao balanço de pagamentos, particularmente a balança comercial, e as reservas internacionais.

- Direta: podemos também utilizar variáveis explicitamente construídas de forma a refletir uma dada percepção de risco. Entre estas, destacam-se, por um lado, as classificações que grandes agências internacionais especializadas em avaliação de risco - as três mais importantes são a Standard \& Poors, Moody's e Fitch - associam aos distintos tipos de títulos de dívida emitidos por governos e empresas; e, pelo outro, o índice EMBI (Emerging Markets Bond Index) e seus derivados $\mathrm{EMBI}^{+}$e EMBI Global, calculados pelo banco JP Morgan, e que representam o diferencial de retorno médio pago por títulos da dívida pública de vários países denominados em moeda estrangeira (o que exclui, portanto o risco de câmbio), em relação aos títulos do Tesouro estadunidense com prazos similares; a diferença entre os três índices encontra-se nos distintos critérios usados para a inclusão de países e de tipos de título. Enquanto variações nas classificações de risco ocorrem de forma lenta, normalmente no máximo uma vez ao ano (salvo em casos de redução mais acelerada nos 
ratings levadas a cabo especialmente durante a ocorrência de graves crises financeiras), e após avaliações por parte de especialistas acerca dos fundamentos da economia do país considerados como relevantes para a avaliação do risco, os índices EMBI, ao referir-se diretamente aos preços de títulos de dívida que podem ser negociados em mercados secundários, têm seus valores reajustados diariamente, em função das variações nesses preços respondendo tanto a informações relacionadas a possíveis alterações nas condições econômicas, políticas e sociais dos países referidos, ou simplesmente aos "humores" dos mercados, genericamente a mudanças em sua aversão ao risco, sem passar necessariamente por uma avaliação mais cuidadosa.

Nos exercícios apresentados a seguir, ambas as abordagens serão alternadamente utilizadas.

\section{Classificação de risco e juros por país}

O primeiro exercício que aqui discutiremos procura verificar a possível relação existente entre as taxas reais de juro, obtidas também aqui a partir da base de dados do IFS-FMI, e a classificação de risco atribuída a cada país pela agência especializada de avaliação Fitch, informação disponível no site internacional da empresa. Para tanto, analisaremos os dados referentes a 44 países, para dois anos distintos, separados por um intervalo de oito anos (1997 e 2005). Os resultados obtidos podem ser vistos nos gráficos a seguir:

\section{Gráfico 6}

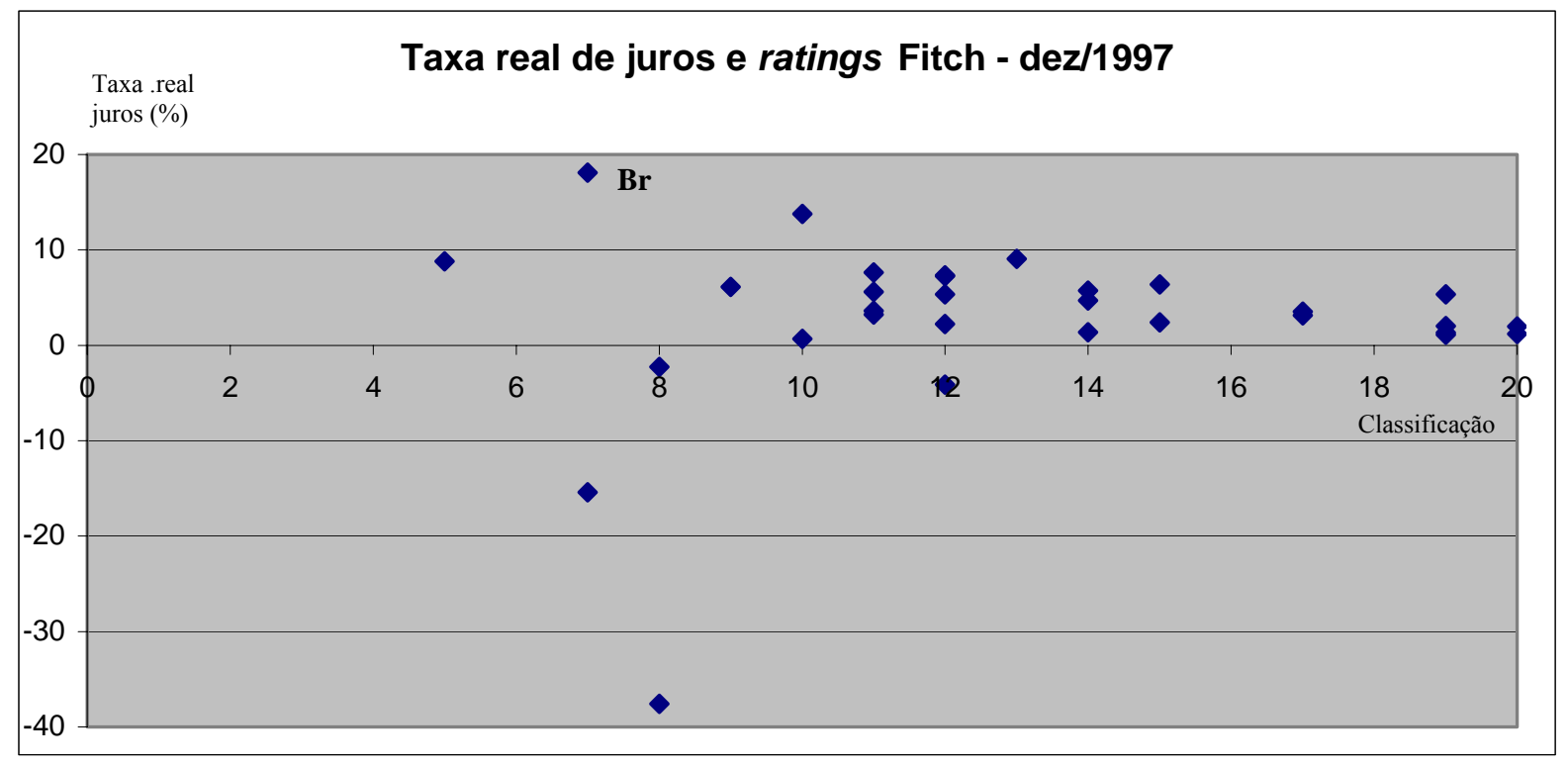

fonte: IFS-FMI e Fitch 


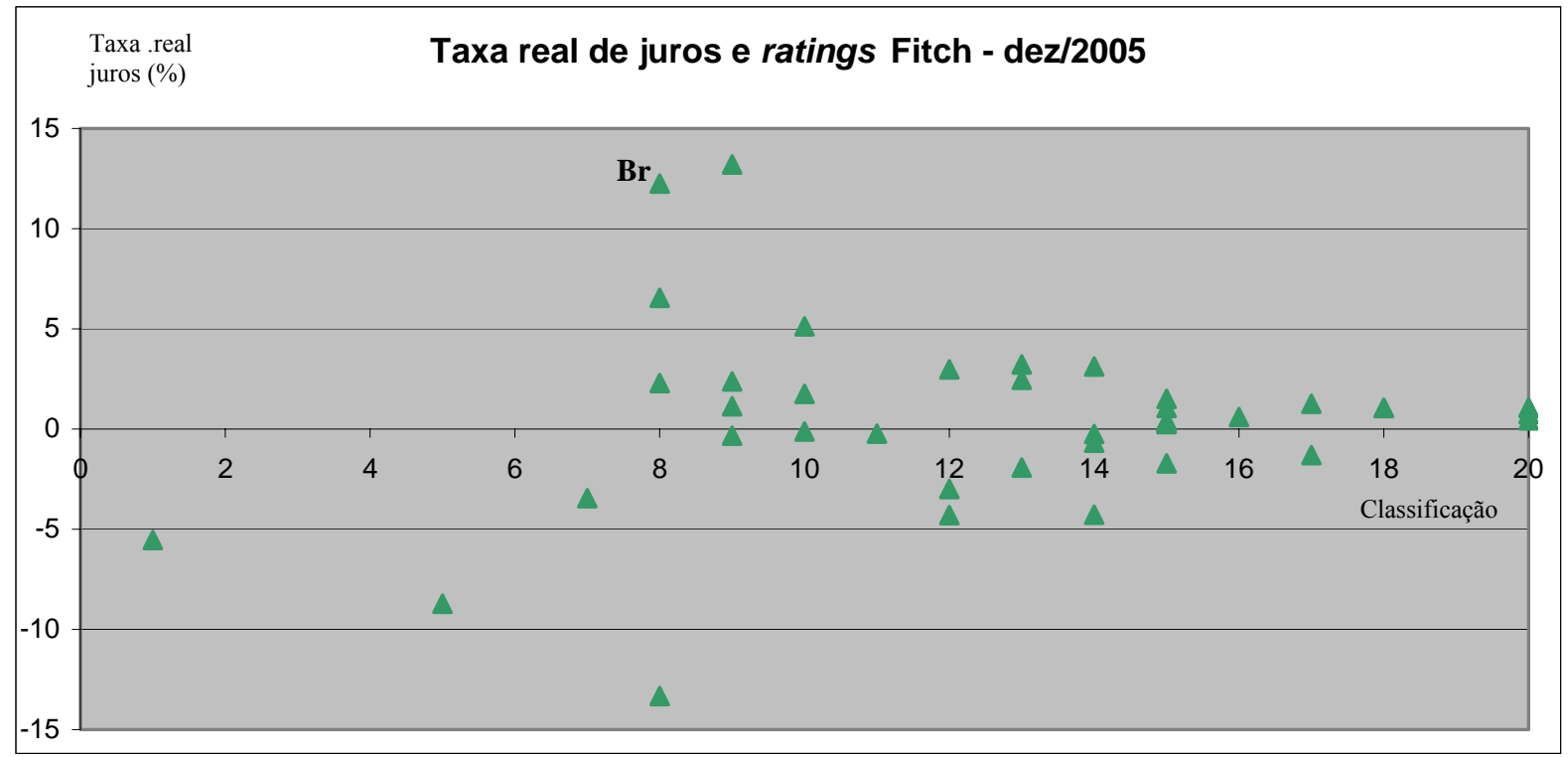

fonte: IFS-FMI e Fitch

Em ambos gráficos, as taxas reais de juro aparecem representadas no eixo $\boldsymbol{y}$, enquanto que a classificação de risco se encontra distribuída ao longo do eixo $\boldsymbol{x}$. Em relação a esta classificação, o valor de 0 corresponde à classificação mais baixa definida pela Fitch (que, como as outras grandes agências, também utiliza um sistema de classificação discreto, baseado em letras), DDD, enquanto o valor de 20 corresponde à classificação mais alta, AAA.

Analisando visualmente as observações contidas nos gráficos para os dois anos, resulta difícil identificar uma correlação clara entre as taxas de juro e a classificação de risco, dada a dispersão das ocorrências ao longo do espectro de classificações. Se alguma, poderíamos talvez evocar uma fraca correlação negativa, a qual seria teoricamente esperada, e que estaria presente nos dois anos, embora de forma um pouco mais evidente em 2005. Esta falta de capacidade em encontrar evidências suficientemente convincentes da relação negativa entre a classificação de risco e as taxas reais de juro para o conjunto de países, parece indicar a pouca relevância desta medida de risco na explicação daquelas taxas,

Outra observação que podemos fazer a partir destes dados refere-se à posição particular ocupada pelo Brasil na distribuição. Para tanto, escrevemos Br nos dois gráficos ao lado da observação correspondente. Constatamos nestes gráficos a posição excepcional ocupada pelo Brasil também quando incorporamos a classificação de risco na análise, já que, oito anos após a estabilização monetária, apesar de não ser o país com a pior avaliação, o Brasil continua pagando as taxas reais de juro mais elevadas da amostra (na verdade, as segundas mais 
elevadas em 2005, atrás apenas da Costa Rica que, entretanto, apresenta classificação de risco ligeiramente superior à brasileira), e isso apesar da pequena melhora verificada no período em relação à classificação de risco indicada pela Fitch (que subiu de de $\mathrm{B}^{+}$em 1997, a BB ${ }^{-}$em 2005). Esta última observação, por sua vez, tem um valor intrínseco, uma vez que não deixa de chamar a atenção o fato de que, apesar das significativas mudanças institucionais e na situação macroeconômica pelas quais o Brasil passou desde a estabilização monetária em 1994, e que certamente continuaram após 1997, a classificação de risco do país praticamente não se alterou. Sendo que as considerações relativas à diminuição da percepção de risco têm sido uma preocupação constante para os formuladores de política econômica, a quase imutabilidade constatada nessa classificação é uma evidência certamente perturbadora em relação ao efetivo sucesso alcançado pelas políticas implementadas nos últimos anos.

\section{Juros e variáveis afetando o risco no Brasil}

Nesta segunda parte, procuraremos analisar, fundamentalmente através de uma verificação gráfica e dos coeficientes de correlação, a evolução mensal, para o caso do Brasil, da taxa real de juros ex-ante desde novembro de 2001 (mês a partir do qual esta taxa pode ser calculada), relacionando-a com as flutuações verificadas nas seguintes variáveis normalmente associadas à percepção de risco:

- Dívida: Dívida Líquida do Setor Público (\% PIB) - (\%/10 - a variável é transformada de forma a poder ser incluída na mesma escala utilizada pela taxa real de juros; transformação semelhante é feita também sobre a variável Export);

- Fiscal: $\quad$ NFSP sem desvalorização cambial (\% PIB) - Fluxo acumulado em 12 meses Resultado primário - Setor público consolidado - \%;

- Bal.Com: Balança comercial/PIB em 12 meses - \%;

- Export: Exportações de bens (fob)/PIB - (\%*10);

- Reservas: Reservas internacionais/PIB - \%. 


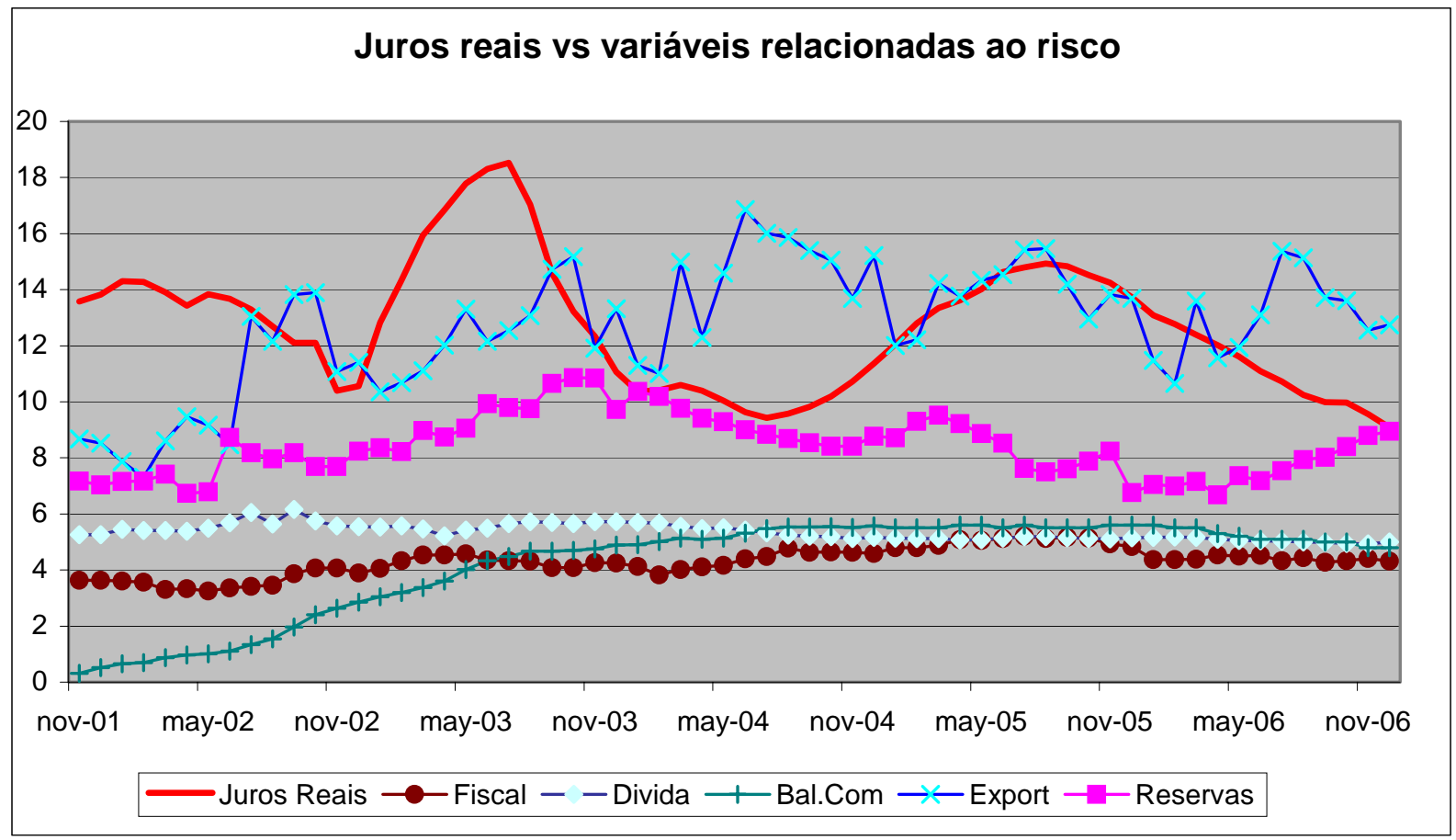

fonte: IBGE e BCB-DEPEC

Ao analisar este gráfico, vemos que as taxas reais de juro têm oscilado significativamente ao longo do período, variando entre 10 e 18\% ao ano, mas que essa oscilação aparentemente não é acompanhada pelo movimento, seja ele simultâneo ou defasado, das variáveis consideradas como normalmente afetando a percepção de risco aqui incluídas, as quais:

- permaneceram estáveis durante praticamente os mais de cinco anos da amostra (como é o caso das variáveis relacionadas à posição fiscal: Fiscal - manutenção de superávits primários flutuando em torno de 4\% durante todo o período; e Dívida - relação dívida/PIB situando-se na maior parte do tempo em níveis pouco acima de 50\%;

- cresceram significativamente de forma contínua (como BalCom, até meados de 2006), ou apresentando oscilações (Export);

- flutuaram consideravelmente durante o período mas sem entretanto apresentar alterações importantes (Reservas) na tendência.

Assim, a partir das impressões recolhidas nesta análise gráfica, não podemos concluir sobre a existência de alguma relação clara e estável no período considerado entre a taxa real de juros e as variáveis selecionadas. Evidências no mesmo sentido podem ser também encontradas ao analisar os coeficientes de correlação entre estas variáveis e aquelas taxas, apresentados na seguinte tabela: 


Tabela 3
\begin{tabular}{|l|c|}
\hline Variável & Correlação \\
\hline Dívida & 0,184 \\
Fiscal & 0,072 \\
Bal.Com & $-0,236$ \\
Export & $-0,271$ \\
Reservas & 0,004 \\
\hline
\end{tabular}
fonte: IBGE e BCB-DEPEC

Vemos que todos os cinco coeficientes calculados apresentam valores reduzidos, indicando a baixa probabilidade de que estas variáveis influenciem individualmente e de forma decisiva as taxas reais de juro. Os coeficientes relativos às variáveis Dívida, Bal.Com e Export, embora pequenos, pelo menos apresentam o sinal de acordo ao que seria teoricamente esperado. Já no caso da variável relativa ao déficit/superávit fiscal (Fiscal), o sinal obtido é oposto ao esperado, dado que aumentos no superávit fiscal deveriam levar à redução do risco e portanto à diminuição das taxas de juro, o que o coeficiente não parece indicar. Outro coeficiente com sinal contrário ao esperado é o relativo às reservas de divisas (Reservas), embora neste caso o coeficiente esteja muito próximo de zero. Assim, tanto a visualização do gráfico quanto a análise dos coeficientes de correlação não fornecem evidências favoráveis para o caso do Brasil da existência de uma relação suficientemente clara e estável entre as flutuações das taxas reais de juros e os movimentos nas variáveis consideradas.

Um parêntesis importante a ser feito neste momento refere-se ao fato de que, ao não encontrar evidências satisfatórias acerca da relação normalmente sugerida entre a posição fiscal e as taxas reais de juro, não somente a validade empírica desta relação quando intermediada pelos efeitos que estas variáveis teriam sobre a percepção do risco é posta em dúvida mas, ao considerar que a falta de evidências se aplica, entre outras, também à variável referente ao déficit/superávit primário sobre o PIB, o eventual efeito direto sobre a taxa de juros resultante da pressão dos gastos públicos sobre a demanda agregada, anteriormente discutido neste trabalho, aparece como altamente questionável.

Voltando às questões relacionadas ao risco, além das medidas indiretas acima consideradas, verificamos no gráfico a seguir a evolução da taxa real de juro em relação às flutuações sofridas pelo índice EMBI (transformado aqui em EMBI/100): 


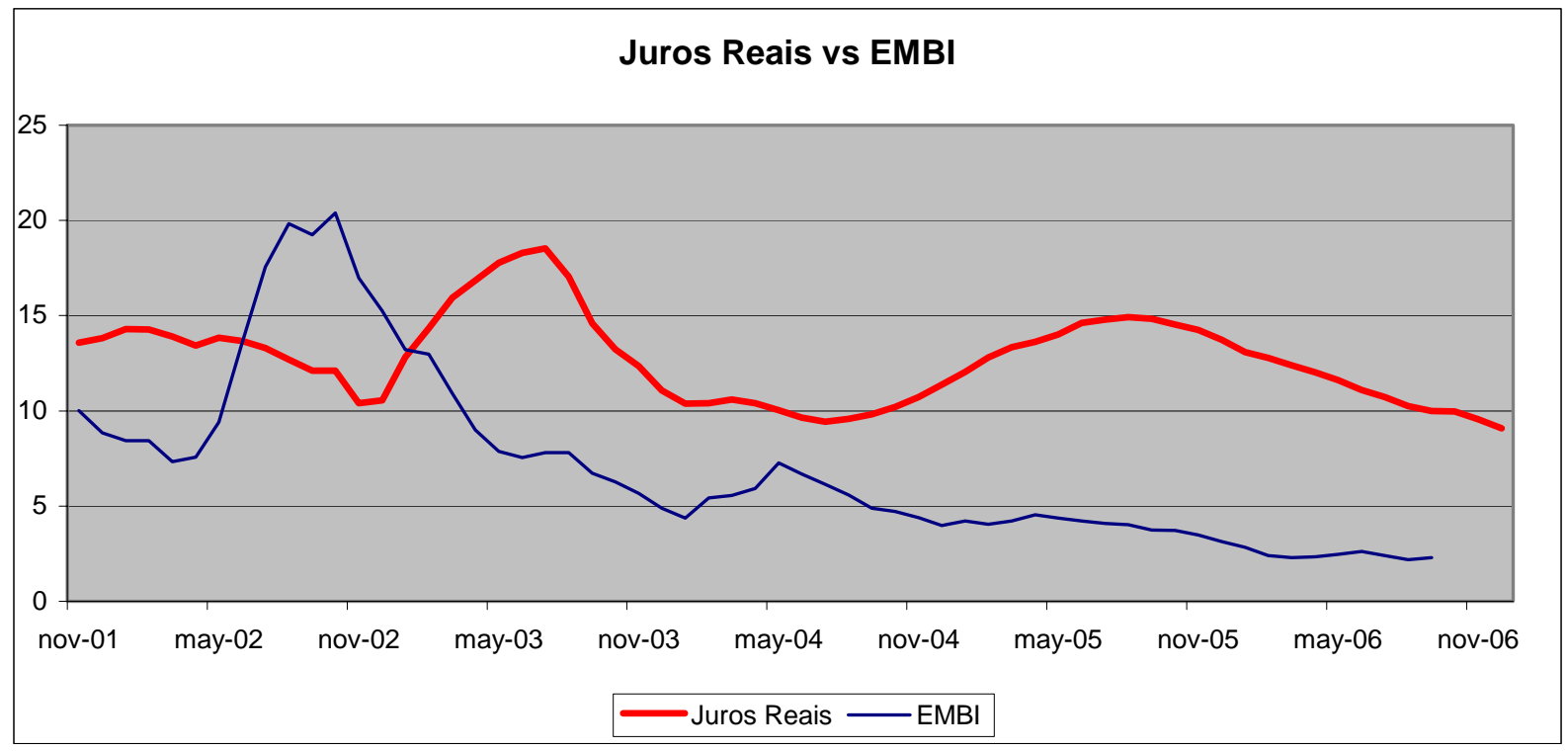

fonte: IBGE e BCB-DEPEC

Aqui, nota-se uma variação conjunta entre as duas variáveis, o que refletiria a possível existência de uma relação de longo prazo entre elas. Efetivamente, variações na taxa real de juros parecem vir precedidas com uma defasagem de algo em torno de nove meses por mudanças similares no valor do índice. Esta impressão é reforçada ao verificar o coeficiente de correlação entre a taxa de juros e o índice EMBI defasado de nove períodos, que alcança o valor de 0,66 , muito superior ao verificado para as variáveis acima apresentadas.

Estas evidências apontam para o fato de que o índice EMBI, diferentemente do verificado acima para outras variáveis que supostamente influenciam o nível de risco percebido, parece ser um bom previsor dos movimentos na taxa real de juros no período analisado. Entretanto, isto não explica por que as flutuaçãoes verificadas nessas taxas, eventualmente seguindo os movimentos no índice aqui estudado, ocorram, no caso do Brasil, em torno de patamares especialmente elevados. Uma forma de obter esse tipo de resposta é por meio de comparações internacionais, que é o que tentaremos fazer no próximo estudo.

\section{Juros e variáveis afetando o risco por país}

A análise empreendida nos dois estudos anteriores, baseadas na observação visual de gráficos construídos de forma a mostrar as possíveis relações entre variáveis consideradas relevantes ou explicitar características de sua evolução conjunta no tempo, assim como a observação e 
comparação dos coeficientes de correlação entre as variáveis, embora possa contribuir com indícios importantes em relação à validade das relações propostas, permitindo-nos inclusive em alguns casos aceitar ou rejeitar a adequação de relações unívocas propostas entre duas variáveis, está sujeita a importantes críticas, especialmente aquelas relacionadas à sua pouca precisão e à sua incapacidade em avaliar o efeito conjunto de várias variáveis explicativas sobre uma variável dependente, e isolar a partir daí os efeitos devidos individualmente a cada uma delas. Assim, procurando contornar os problemas apontados por essas críticas, foi realizado um curto trabalho econométrico, apresentado a seguir, que deve complementar e qualificar as evidências obtidas nos estudos acima discutidos.

Desta forma, o último estudo original que veremos nesta seção consiste na estimação de um modelo em painel com dados obtidos do International Financial Statistics do Fundo Monetário Internacional (FMI), referentes a dez países em desenvolvimento (Argentina, Bulgária, Colômbia, Equador, México, Marrocos, Peru, Filipinas, Polônia e Turquia) além do Brasil, usando dados trimestrais para o período compreendido entre o primeiro trimestre de 1995 e o segundo trimestre de 2006, no qual ocorreram várias crises financeiras internacionais importantes, a última das quais teve seu foco na Argentina (e reflexos significativos no risco percebido de outros países, principalmente na América Latina) no início de 2001, mas que desde então globalmente apresenta uma relativa calmaria. Os países escolhidos para este estudo fazem parte da lista relativamente reduzida de países para os quais é calculado o índice $\mathrm{EMBI}^{+}$, e que são considerados para efeito de avaliação de risco como contendo importantes características em comum com o Brasil, e daqui o sentido da escolha.

Com este estudo, pretende-se identificar eventuais relações existentes entre algumas variáveis escolhidas, discutidas nas seções anteriores, e as taxas reais de juro.

O modelo estimado é baseado na seguinte equação:

$$
i_{i t}=\beta_{1} e x_{1 i t}+. .+\beta_{n} e x_{n i t}+\gamma_{1} f p_{1 i t}+. .+\gamma_{s} f p_{s i t}+\delta_{1} r i_{i t}+\delta_{2} d s_{i t}+\delta_{3} i v_{i t}+\mu_{i t}
$$

onde,

$j_{i t}: \quad$ taxa real de juros do país $i$ no período $t$;

$\boldsymbol{e x}_{\text {nit: }}$ : variável $\mathrm{n}$ referente às contas externas do país $i$ no período $t$; 
$f_{p_{\text {sit }}}$ : variável s referente às finanças públicas do país $i$ no período $t$;

$\boldsymbol{r i}_{i t}: \quad$ índice $\mathrm{EMBI}^{+}$do país $i$ no período $t$;

$\boldsymbol{d s}_{\mathrm{it}}: \quad$ desemprego do país $i$ no período $t$;

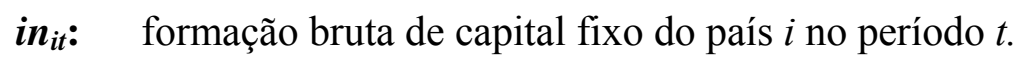

A influência de diferentes níveis de risco sobre as taxas reais de juro é medida através da significância e dos valores obtidos para os coeficientes das seguintes variáveis, testadas usando diversas configurações, em conjunto ou separadamente:

Relativas às contas externas:

reserv: reservas internacionais/PIB;

export: exportações/PIB;

balcom: saldo da balança comercial/PIB;

catcorr: saldo de transações correntes/PIB;

Relativas às finanças públicas:

fiscal: déficit-superávit primário/PIB;

gov: gastos do governo/PIB.

Estes dois conjuntos de variáveis incluem aquelas que, como vimos na discussão acima, afetariam indiretamente a percepção do risco de um país, enquanto que o índice $\mathrm{EMBI}^{+}$ (embi) busca captar essa percepção de forma objetiva a partir dos preços em que os títulos emitidos pelo país são transacionados.

Além destas variáveis, são introduzidas as seguintes duas variáveis de controle, de forma a isolar seus efeitos e testar as seguintes hipóteses:

- Desemprego - desemp (em \%): níveis mais baixos de desemprego tendem a indicar uma situação de aquecimento da atividade econômica, com o produto mais próximo ou mesmo superando o produto potencial, o que tenderia eventualmente a gerar pressões inflacionárias, levando, como forma de controlá-la, ao aumento da taxa real de juros. Por outro lado, maior aquecimento da economia e menores níveis de desemprego podem ser conseqüência de taxas de juro mais baixas. 
- Formação bruta de capital fixo - $f b c f$ (\% em relação ao PIB): países com altos níveis de investimento necessitariam de uma maior disponibilidade de poupança, o que se obteria com juros mais elevados. Por outro lado, níveis elevados de investimento podem refletir melhores perspectivas em relação ao diferencial de rendimentos esperado de novos projetos favorecidas por juros mais baixos.

A partir da definição deste conjunto de variáveis, procuramos estimar distintas configurações do modelo, as quais variam justamente em função das variáveis que nele são incluídas, de forma a obter aquele que melhor se adapte aos dados observados.

Optou-se pela utilização de um modelo em painel com efeito fixo, já que a hipótese deste trabalho implica justamente em que as variáveis normalmente evocadas e testadas neste estudo não se mostrariam suficientes para explicar as diferenças verificadas nos níveis das taxas reais de juro; dessa forma, fatores não incluídos no modelo, razoavelmente constantes no tempo e intrínsecos a cada país, seriam importantes na explicação dessas diferenças. Neste tipo de situação, o modelo em painel costuma normalmente ser indicado.

Efetivamente, ao procurar estimar de forma exploratória o modelo sem a inclusão do efeito fixo, praticamente todas as configurações testadas apresentaram os coeficientes como não significativos, apontando de maneira bastante clara para a não adequação do modelo.

Ao realizar a estimação incluindo, portanto, o efeito fixo, a primeira observação que podemos fazer se refere ao fato de que os coeficientes relativos às duas variáveis de controle, tanto o desemprego quanto a formação bruta de capital fixo, não se apresentaram significativos, seja individualmente ou combinados, na grande maioria das configurações testadas, indicando a provável pouca relevância destas variáveis na determinação das taxas reais de juro.

Um segundo ponto se refere ao fato de que, ao introduzir o índice EMBI na estimação, os coeficientes de várias das variáveis relativas ao risco se tornam não significativos, como seria normalmente esperado em virtude da ocorrência de um grau provavelmente elevado de colinearidade entre o embi e essas outras variáveis. Em função deste problema, e da conveniência em distinguir claramente os resultados obtidos pelas duas formas de natureza distinta de considerar o risco, optou-se por apresentar duas estimações separadas, sem e com a inclusão do índice. 
Na primeira estimação, em que excluímos a variável embi e, após testar várias combinações possíveis entre as variáveis relacionadas à posição fiscal e à vulnerabilidade externa, incluindo e excluindo um ou ambos os controles (que como vimos em regra geral se apresentam como não significativos), chegamos às seguintes conclusões:

- A variável balcom se mostra, como seria normalmente esperado, altamente correlacionada com as variáveis ctacorr e export, fazendo com que sua inclusão conjunta na estimação resulte em coeficientes não significativos; o problema não aparece tão grave quando apenas as duas últimas variáveis são incluídas. Por outro lado, a mesma situação ocorre, embora em menor grau, quando são incluídas conjuntamente as duas variáveis relacionadas às contas públicas, fiscal e gov.

- As variáveis ligadas às contas externas aparecem com coeficientes significativos de maneira mais freqüente do que ocorre com as variáveis relacionadas às contas públicas, fornecendo um indício (fraco) de sua maior importância relativa.

- Após testar o desempenho de várias configurações possíveis em termos da significância dos coeficientes, concluímos que, embora mais de uma delas tenha apresentado resultados satisfatórios, os melhores resultados são obtidos quando utilizamos apenas balcom como variável relativa às contas externas, e fiscal em relação às contas públicas, reduzindo significativamente dessa forma os problemas devidos à multicolinearidade. A estimação assim obtida é apresentada na seguinte tabela:

\section{Tabela 4}

Dependent Variable: JUROS

Method: Panel Least Squares

Sample: 1995Q1 2006Q2

Cross-sections included: 10

Total panel (unbalanced) observations: 370

\begin{tabular}{crrrr}
\hline \hline Variável & Coeficiente & Std. Error & t-Statistic & Prob. \\
\hline \hline C & $\mathbf{3 . 4 6 3 9 6 8}$ & 0.721850 & 4.798739 & 0.0000 \\
BALCOM & $\mathbf{- 0 . 5 6 4 3 8 1}$ & 0.152217 & -3.707749 & 0.0002 \\
FISCAL & $\mathbf{- 0 . 2 5 0 7 4 8}$ & 0.093891 & -2.670635 & 0.0079 \\
\hline \hline
\end{tabular}


Este resultado constitui-se efetivamente em indício válido da existência de uma relação entre as variáveis ligadas às contas públicas e externas e a taxa real de juros. Entretanto, o valor relativamente baixo apresentado pelos coeficientes estimados (lembrando que tanto balcom como fiscal são definidos em \%) coloca dúvidas em relação à capacidade destas variáveis em explicar satisfatoriamente os níveis em torno dos quais essas taxas flutuam. De fato, é importante lembrar que a utilização do efeito fixo levada a cabo neste exercício é justamente indicada quanto fatores não incluídos na estimação apresentam papel significativo na explicação dessas taxas. Uma noção da importância destes fatores nessa explicação pode ser obtida analisando os valores calculados na estimação para os efeitos fixos correspondentes a cada um dos países na amostra, os quais são apresentados na tabela a seguir:

$\begin{array}{lr}\text { Tabela } 5 & \\ \text { Efeito Fixo } & \text { Cross-Section } \\ \text { Argentina } & 3.4749 \\ \text { Brasil } & \mathbf{8 . 8 3 0 3} \\ \text { Bulgária } & -14.2856 \\ \text { Colômbia } & 5.7584 \\ \text { México } & 4.3490 \\ \text { Marrocos } & 0.4269 \\ \text { Peru } & -9.6415 \\ \text { Filipinas } & 3.7160 \\ \text { Polônia } & -5.4094 \\ \text { Turquia } & -4.9066\end{array}$

Nota-se nesta tabela que, efetivamente, os valores (em módulo) aqui apresentados são todos, com exceção do referente ao México, bastante elevados. Embora os coeficientes estimados relativos ao efeito fixo sejam inconsistentes, não podemos deixar de notar que o valor encontrado para o Brasil é efetivamente o mais elevado da amostra, resultado compatível com aquele encontrado no trabalho de Muinhos e Nakane, indicando com isso que os fatores não incluídos no modelo, intrínsecos a cada país, seriam particularmente relevantes, especialmente no caso do Brasil, para explicar as taxas reais de juro.

Juros e EMBI

A segunda estimação aqui apresentada inclui apenas a variável referente ao índice embi que como apontamos acima, apresenta elevada colinearidade com as demais variáveis normalmente associadas à percepção de risco. Da mesma forma que na primeira estimação, 
novamente as variáveis de controle aparecem como não significativas, e são, portanto também excluídas. Os resultados obtidos na estimação são apresentados na seguinte tabela:

\begin{tabular}{lllll} 
Tabela 6 & & & \\
Dependent Variable: JUROS & & \\
Method: Panel Least Squares & & & \\
Sample (adjusted): 1998Q4 2006Q2 & & & \\
Cross-sections included: 11 & & & \\
Total panel (unbalanced) observations: 324 & & \\
\hline \hline Variável & Coeficiente & Std. Error & t-Statistic & Prob. \\
\hline \hline C & $\mathbf{5 . 3 1 3 1 4 1}$ & 1.009515 & 5.263062 & 0.0000 \\
EMBI & $\mathbf{- 0 . 0 0 2 5 2 2}$ & 0.000893 & -2.823304 & 0.0051 \\
\hline \hline
\end{tabular}

Vemos aqui a significância do coeficiente da variável embi, o que indica que o índice teria alguma importância na explicação das taxas reais de juro. Entretanto, o sinal negativo obtido para o coeficiente, embora muito próximo de zero, resulta perturbador, uma vez que significa que valores mais elevados para o índice, o que normalmente representa riscos também mais altos, conduziriam a taxas de juros menores, o que certamente não é esperado. Este tipo de problema não ocorreu na estimação acima, em que os sinais dos dois coeficientes, negativos, estavam em concordância com que seria teoricamente esperado (superávits comerciais e fiscais primários mais elevados levariam a taxas de juro menores).

Além desta importante ressalva em relação ao sinal do coeficiente, aqui também se aplica o comentário relativo à possível importância do efeito fixo na explicação das taxas verificadas. Os valores calculados nesta estimação são apresentados na tabela a seguir:

$\begin{array}{lr}\text { Tabela } 7 & \\ \text { Efeito Fixo Cross-Section } \\ \text { Argentina } & 7.0356 \\ \text { Brasil } & \mathbf{8 . 5 3 6 7} \\ \text { Bulgária } & -6.5966 \\ \text { Colômbia } & 2.4699 \\ \text { Equador } & -9.4408 \\ \text { México } & -0.3145 \\ \text { Marrocos } & -1.7669 \\ \text { Peru } & 2.5135 \\ \text { Filipinas } & -1.5214 \\ \text { Polônia } & -2.8955 \\ \text { Turquia } & 2.9619\end{array}$


Notam-se novamente nesta tabela os elevados valores (em módulo) obtidos para os efeitos fixos. E, novamente, o valor encontrado para o Brasil é o mais elevado da amostra, reforçando a impressão de que outros fatores que não os que foram discutidos até o momento seriam fundamentais para explicar as taxas reais de juro vigentes no país.

\section{Conclusão}

Antes de mais nada, é preciso ressaltar o caráter meramente explorátório dos estudos aqui apresentados. De fato, sua inclusão neste trabalho não tem de forma alguma a pretensão de aportar novos e contundentes elementos que comprovem ou rejeitem claramente a existência de uma relação determinante entre as variáveis relativas à percepção do risco e as taxas reais de juro. Apenas, dada a relativa escassez de trabalhos que discutam explicitamente a questão e apresentem evidências em favor de uma das duas posições - provavelmente, por considerar que a relação aqui abordada é um fato generalizadamente aceito não necessitando, portanto, de verificações empíricas - considerou-se conveniente a inclusão destes estudos de maneira a fornecer novos indícios que contribuam na discussão desta questão.

Em linhas gerais, as conclusões que podem ser retiradas a partir dos resultados obtidos por estes estudos são compatíveis com aquelas encontradas no trabalho de Muinhos e Nakane (2006) acima citado. A partir deste trabalho, e dos estudos originais acima apresentados, podemos retirar as seguintes conclusões principais:

- As evidências a favor da relação entre as taxas reais de juro e as variáveis normalmente apontadas como influenciando o nível de risco, fundamentalmente as relacionadas às contas públicas e aquelas representando a situação externa, são normalmente fracas. Tanto no trabalho de Nakane e Muinhos (especialmente em relação às variáveis fiscais) quanto no segundo estudo aqui apresentado, focando exclusivamente o caso particular do Brasil, as evidências são contrárias à relevância destas variáveis na determinação daquelas taxas, tanto no que se refere a seus níveis quanto em relação às variações em torno a eles. A primeira parte do último estudo, por outro lado, mostra indícios de que tais variáveis teriam algum papel a jogar nessa determinação, embora tal papel pareça pequeno. Basicamente, podemos dizer que não encontramos evidências suficientes que indiquem uma relação importante entre os dois conjuntos de variáveis e as taxas reais de juro. 
- O índice EMBI, por sua vez, parece estar relacionado de maneira mais estreita com as flutuações nas taxas reais de juro. De fato, esta medida capta de forma mais adequada o conjunto das considerações de risco que afetam a determinação das taxas de juro, fato pelo qual é capaz de explicar parte importante de suas variações. Entretanto, quando usada para explicar as diferenças encontradas nos patamares das taxas praticadas em diferentes países, e a particularidade do caso brasileiro, esta variável não apresentou resultados satisfatórios, como pôde ser claramente notado no último estudo aqui apresentado.

- As classificações de risco elaboradas por agências especializadas, como verificado no trabalho de Muinhos e Nakane e no primeiro estudo aqui apresentado, também não parecem capazes de apresentar resultados satisfatórios ao tentar explicar os níveis alcançados pelas taxas reais de juros. Efetivamente, ambos trabalhos mostram que não parece haver uma relação direta entre estas classificações e as taxas praticadas em distintos países.

Como conclusão geral desta seção, podemos dizer que não foram encontradas evidências suficientes que nos permitam aceitar a afirmação que pretende que fatores normalmente associados às considerações de risco, especialmente as medidas relacionadas à situação físcal e à solvabilidade externa do país, ou variáveis que procuram captar de forma direta o risco associado aos títulos de dívida, como o índice EMBI e as classificações de risco, seriam os principais determinantes das elevadas taxas reais de juro praticadas no Brasil. Como sugerido pelos elevados coeficientes encontrados para os efeitos fixos, tanto no trabalho de Muinhos e Nakane quanto no último estudo aqui apresentado, outros fatores, convencionalmente não considerados na discussão deste assunto, parecem ser relevantes para explicar as diferenças constatadas nos patamares das taxas reais de juros praticados em diferentes países, e dessa forma a singularidade do caso do Brasil.

Além dos resultados do trabalho empírico citado e daqueles obtidos a partir dos estudos originais apresentados nesta seção, cujas conclusões foram acima expostas, pesam contra aquela afirmação, como procurei mostrar nas seções anteriores, críticas teóricas e evidências empíricas importantes relacionadas à maneira com que a lógica que a sustenta é construída. Nesse sentido, vimos acima, por um lado, críticas e evidências contrárias à relação entre as variáveis fiscais e externas e o risco-país, e pelo outro, qualificações da relação existente entre este risco e as taxas de juro. Não se pretende aqui negar a consistência lógica da abordagem 
teórica que relaciona fatores que afetam o risco às taxas reais de juro; tampouco se afirma que tais relações não se verifiquem de fato, pelo menos em algum grau, na prática. $\mathrm{O}$ que a discussão conduzida até este momento pretende, ao apontar para as importantes insuficiências apresentadas por esta abordagem, é fundamentalmente relativizar a relevância teórica e sobretudo empírica das relações por ela defendidas.

Tal tarefa resulta tanto mais indicada se considerarmos que as insuficiências e dúvidas aqui colocadas, todas elas já conhecidas - embora não de forma necessariamente integrada como se procurou aqui fazer -, e especialmente importantes no que se refere ao papel jogado pelas considerações relativas à situação das contas públicas na determinação das taxas reais de juro, não têm impedido que recomendações baseadas na validade desta hipótese sejam rotineiramente feitas, como por exemplo, nos trabalhos de Garcia (2003) e Barbosa (2006). Neste sentido, não deixa de chamar a atenção a insistência com que recomendações relacionadas à obtenção de elevados superávits primários como caminho para a redução das taxas reais de juro são feitas, uma vez que, como vimos, não existem em geral, e especialmente para o caso do Brasil, indicativos suficientemente claros de que essa relação seja empiricamente relevante. Igualmente surpreendente é a defesa recorrente que se faz da idéia de que o motivo para as taxas reais de juros ainda serem muito elevadas no Brasil, e isto apesar da manutenção ao longo de já vários anos de consistente esforço fiscal com a obtenção de inéditos superávits primários, estaria no fato de que tal esforço seria, ainda, insuficiente.

\section{Considerações Finais}

Ao longo da parte do trabalho que aqui se encerra, procurei realizar um exame relativamente amplo de várias teorias colocadas no campo da ortodoxia que buscam explicar as elevadas taxas reais de juro vigentes no Brasil em comparação com as taxas válidas para outros países. Após analisar as teorias que buscam explicar a determinação das taxas reais de juros a partir:

- da taxa natural de juro particularmente elevada no Brasil;

- do caráter inercial da inflação;

- da incerteza jurisdicional;

- da pressão excessiva dos gastos do Governo sobre a demanda;

- de considerações variadas relacionadas ao risco; 
criticando teórica e empiricamente tais explicações à luz de evidências obtidas tanto a partir de trabalhos que têm discutido o assunto e procurado aportar novos resultados, quanto dos resultados encontrados nos três estudos originais aqui apresentados, concluímos que nenhuma dessas teorias é capaz de fornecer soluções satisfatórias à questão colocada. Embora existam evidências que coloquem algumas das variáveis analisadas como efetivamente relevantes na explicação da determinação dos movimentos verificados nas taxas de juro, como ocorre por exemplo com o índice EMBI, a manutenção de elevados patamares para essas taxas, em torno dos quais as flutuações ocorrem, durante um período prolongado de tempo, permanece sem explicação satisfatória no campo da teoria ortodoxa. Nesse sentido, as comparações internacionais discutidas no trabalho, que permitiriam eventualmente identificar elementos singulares no caso do Brasil, os quais poderiam ser relevantes para a determinação da taxa real de juros, também não se mostraram capazes de contribuir para a solução da questão.

Com isto, novamente, não pretende-se aqui negar a validade teórica e empírica das teorias discutidas ao longo do capítulo, que podem efetivamente ter seu papel na explicação de parcela importante das taxas reais de juro em geral e da singularidade da situação brasileira em particular, ao longo de todo o período considerado ou especialmente em conjunturas particulares, e ser desta forma úteis como contribuição para uma explicação abrangente da questão. O que espero ter conseguido com este trabalho é simplesmente qualificar a importância de tais contribuições, certamente questionando-lhes a posição de explicações centrais e determinantes para o problema, posição na qual tais teorias são normalmente colocadas pela constância e ênfase com que têm sido evocadas no debate tanto público quanto acadêmico, abrindo dessa forma espaço para que outras abordagens para esta questão, eventualmente mais apropriadas, possam emergir.

E isto somente será possível quando teorias como as que foram acima analisadas deixem de ser apresentadas e intensamente difundidas, tanto no debate no meio acadêmico quanto para um público mais amplo através da imprensa especializada e geral, na condição de verdades incontestes as quais inclusive não precisam de comprovação empírica, e com isso não possam continuar a ser evocadas de forma quase automática - como tem frequentemente ocorrido para justificar as escolhas de política econômica e as maneiras de implementá-las.

Finalmente, e como conclusão do esforço aqui empreendido com o objetivo de relativizar a importância das teorias ortodoxas que têm abordado o assunto, podemos fazer uma última 
observação, que se refere ao fato de que, considerando a importância das taxas reais de juro para o funcionamento global da economia, suas implicações sobre o ritmo de crescimento econômico e sobre a distribuição de renda, e dada sua relevância prática imediata - uma vez que não discutimos aqui uma situação hipotética mas uma realidade que tem se mantido com todas suas imposições ao longo de um período particularmente extenso para os padrões brasileiros de política econômica - resulta no mínimo surpreendente, ou talvez sintomático, que a teoria econômica ortodoxa não tenha sido até o momento capaz de fornecer justificativas que possam ser empiricamente comprovadas para a vigência de uma situação tão peculiar no Brasil. 


\section{POLÍTICA MONETÁRIA E JUROS}

Não tendo encontrado nas teorias econômicas ortodoxas as explicações para as excepcionais taxas reais de juro brasileiras, resta, entretanto a justificativa, freqüentemente avançada, embora, eventualmente - dependendo de como é colocada - redundante, de que tais taxas seriam naturalmente decorrentes da política monetária seguida pelo Banco Central. Assim, apesar de não conseguir comprovar a relação direta entre as variáveis anteriormente sugeridas e as taxas reais de juro, buscar-se-ia estabelecer essa relação de forma indireta ao considerar a política monetária, cuja condução é assumida como sendo responsável pelas taxas de juro, como fundamentada nas teorias econômicas discutidas no capítulo anterior, embora se aceite a rejeição destas em testes empíricos. Uma explicação para esta aparente contradição que podemos às vezes encontrar na literatura atribui a rejeição empírica daquelas teorias a problemas variados relativos à construção e execução dos testes e à eventual insuficiência de dados. Nesta visão, supõe-se implicitamente que o conjunto das teorias apresentadas, ou pelo menos parte importante delas, não seria equivocado ou pouco relevante mas, ao contrário, efetivamente capaz de responder satisfatoriamente à questão colocada - de por que as taxas reais de juro são tão elevadas no Brasil; a inexistência até o momento de efetiva comprovação empírica de sua validade dever-se-ia apenas ao fato de que, dadas as limitações acima, não teria sido ainda possível testá-las adequadamente. Até que isso ocorra, e embora esta solução suscite certo incômodo, a comprovação dessas teorias se daria, como vimos, de forma indireta, ao considerá-las como fundamentando o desenho e execução da política monetária, no bojo da qual se daria a determinação das elevadas taxas verificadas.

Entretanto, a maneira que tem se mostrado mais comum de tratar este problema, ao invés de apontar para falhas nos testes e remeter sua solução a eventuais trabalhos futuros, tem sido simplesmente não abordá-lo - ou mesmo, não reconhecê-lo como tal; deste ponto de vista, não causa tanta surpresa a escassez, apontada acima, de trabalhos que procurem comprovar empiricamente, principalmente por meio de comparações internacionais mas também, por exemplo, para o caso de um mesmo país, através de estudos de cointegração, as teorias normalmente sugeridas para explicar os diferenciais das taxas reais de juro. Esta escassez contrasta com a relativa abundância de trabalhos, teóricos e empíricos, tanto internacionais quanto focados no caso específico do Brasil, apresentados nos últimos anos com o objetivo de estimar e discutir a função de reação do Banco Central, colocada no centro da análise relativa à execução da política monetária. Ao fazer esta escolha, e concentrar a análise na dinâmica 
que pauta o funcionamento da política monetária como tema principal a ser investigado, evitase a necessidade de discutir as razões particulares pelas quais essa dinâmica conduziria, no caso específico do Brasil, a resultados tão excepcionais em termos de taxas reais de juro. Busca-se prescrever as variáveis às quais a política monetária deveria reagir, e estimar as variáveis às quais ela teria de fato reagido, sem precisar discutir as razões que explicariam, fora da dinâmica interna do próprio modelo usado, porque essas ações no caso brasileiro teriam se articulado de tal maneira a conduzir àquelas taxas. Restringimos-nos desta forma a discutir apenas as flutuações das taxas, sem encarar o problema referente aos níveis em torno dos quais tais flutuações ocorreriam. Assim, a singularidade acima apontada não é sequer considerada como tal, sendo a situação apenas vista como uma contingência temporária, que seria normalmente eliminada com o passar do tempo - posição cada vez mais difícil de defender, dada a continuidade das elevadas taxas ao longo dos anos -, como decorrente da necessidade de ajustes finos na política, ou como uma característica inerente à economia brasileira - retornando assim à taxa natural - e somente modificável, portanto de forma lenta e através de profundas reformas estruturais. Nesta visão, a rationale da manutenção no Brasil de particularmente elevadas taxas reais de juro raramente é colocada em questão.

Pelo contrário, buscando as razões que expliquem esta situação particular, das quais, como vimos no capítulo anterior, não se encontram evidências satisfatórias ao examinar as teorias tradicionalmente avançadas pela ortodoxia, procurarei nesta parte do trabalho verificar se tais razões podem ser, como freqüentemente proposto, identificadas em requisitos peculiares à maneira com que a política monetária é conduzida no Brasil.

Inicialmente, é necessário afirmar que a relação direta entre a política monetária e as taxas reais de juro é dificilmente questionável, uma vez que o instrumento por excelência utilizado na execução da política monetária praticada no Brasil desde a implementação do Plano Real e, de forma mais explícita, após a adoção do regime de metas de inflação (analisado mais adiante), é justamente o ajuste da taxa de juros nominal de curto prazo através da fixação por parte do Banco Central de metas para a taxa de remuneração sobre suas reservas; com este tipo de ajuste, como vimos anteriormente, definem-se quase que diretamente as taxas reais de juro. Ou seja, afirmar simplesmente que a taxa de juros depende da política monetária não acrescenta nenhuma informação particularmente útil ao debate. $O$ ponto que certamente merece ser discutido refere-se a quais seriam as variáveis relevantes e de que maneira elas atuariam sobre a política monetária de forma a que esta resulte na definição de um nível 
determinado daquelas taxas, pois não há, evidentemente, nada nesta lógica que indique $a$ priori quais deveriam ser as taxas de juro adequadas a ser definidas pelo Bacen na condução da política monetária, que é a questão na qual estamos interessados. Para encontrar a resposta a esta questão, devemos, portanto investigar as características e os determinantes daquela política, procurando elementos que eventualmente justifiquem a singularidade do caso do Brasil.

\section{Qual Política Monetária?}

A política monetária praticada nos últimos anos no Brasil pode ser associada ao que, como discutido por Piza e Dias (2006) e Le Heron (2003), vem se caracterizando como um novo consenso macroeconômico, o qual incluiria um núcleo central de idéias cujos princípios têm sido amplamente aceitos tanto em círculos acadêmicos quanto entre banqueiros centrais e formuladores da política monetária de um modo geral, cujas discordâncias referir-se-iam fundamentalmente aos detalhes envolvidos (McCallum, 2002). Estaria inclusive ocorrendo, no quadro deste consenso, uma reaproximação, após um período de relativo afastamento, entre o trabalho acadêmico e a execução prática da política econômica, favorecendo com isso sua interação. É também no quadro deste consenso que procurarei nesta parte de trabalho discutir alguns pontos que têm caracterizado a maneira com a qual a política monetária vem sendo manejada no Brasil.

Os conceitos teóricos centrais que caracterizariam este consenso ao qual a maioria dos economistas, pelo menos dentro do campo da ortodoxia, têm aderido, podem ser resumidos nos seguintes pontos (Taylor, 1998):

- O crescimento do produto real de longo prazo, ou produto potencial, pode ser entendido através do modelo de crescimento neoclássico com tecnologia endógena.

- Não há trade-off de longo prazo entre inflação e desemprego. Assim, no longo prazo a política monetária somente afeta a inflação, sendo neutra em relação às variáveis reais. Isto implica que os Bancos Centrais deveriam apenas escolher uma meta de inflação de longo prazo e guiar suas ações com o objetivo principal - quando não único - de atingir essa meta. 
- No curto prazo, existe um trade-off entre inflação e desemprego. Embora as razões que justifiquem esse trade-off ainda não estejam totalmente claras, tende-se a concordar que ele é causado, principalmente, pela rigidez temporária de preços e salários. Em função desse trade-off, a política monetária deve buscar manter o crescimento estável da demanda agregada para prevenir flutuações no produto real e na inflação, o que se conseguiria em boa medida com uma política monetária estável.

- Expectativas são altamente sensíveis a decisões de política; assim, o impacto das expectativas deve ser considerado na definição de políticas fiscais e monetárias. A maneira mais adequada de modelar este princípio é através da introdução das expectativas racionais.

- Os policymakers devem fazer mudanças de forma gradual, seguindo regras claras.

Tomando por base estes conceitos, é desenvolvido um modelo macroeconômico estrutural (portanto considerado como sendo invariante a mudanças de política) que, apesar de poder ser construído de diversas maneiras, com diferentes níveis de complexidade ao envolver mais ou menos equações ou variáveis, e incorporar em sua dinâmica de forma mais ou menos explicita os fundamentos microeconômicos, parte sempre, basicamente, de um sistema dinâmico estocástico simples contendo três equações e três variáveis, inflação, produto e taxa de juros. A primeira equação representa uma curva IS que relaciona as variações no produto a mudanças no nível das taxas reais de juro. A segunda equação é fundamentalmente uma curva de Phillips aumentada pelas expectativas, que relaciona o comportamento dos preços, e assim da inflação, a variações na capacidade produtiva e nas expectativas; de acordo com esta relação, aumentos do produto real acima do produto potencial, gerando pressões de demanda, e expectativas prevendo o aumento de preços, pressionam a inflação. Finalmente, a terceira equação consiste numa função de reação do Banco Central, que relaciona a taxa de juros à inflação (e eventualmente a outros fatores, especialmente o hiato do produto, mas também, por exemplo, a taxa de câmbio); em caso de elevação da inflação, e de acordo com os parâmetros desta função, o Banco Central reagiria aumentando as taxas nominais de juros de forma que as taxas reais (considerando o caráter parcial e gradual dos ajustes de preços nominais) também se elevassem, por um lado pressionando negativamente a demanda agregada e inibindo o aumento de preços, e pelo outro revertendo as expectativas de aumento da inflação, com o que se alcançaria o seu controle. 
Os conceitos acima discutidos ganham seu pleno significado e o modelo atinge sua maior aplicabilidade quando associados ao regime de metas de inflação (MI), embora tanto os conceitos quanto o modelo em si não restrinjam seu sentido unicamente a este regime. Isto implica dizer que em regimes monetários alternativos tais como, por exemplo, o de câmbio fixo adotado no Brasil entre 1994 e o início de 1999 - até a desvalorização do Real -, outros determinantes que não fazem parte do núcleo apresentado acima mas que afetam decisivamente a maneira com que a política monetária é conduzida, deveriam ser especialmente levados em conta, fundamentalmente, neste caso, a manutenção da paridade fixa da moeda. Assim, apesar de não considerar a mudança de regime uma ruptura significativa no que se refere à concepção teórica acerca do funcionamento da economia, além de que a maior parte das idéias acima e adiante discutidas possam também ser aplicadas ao regime de câmbio fixo, a discussão levada a cabo a seguir resulta particularmente adequada ao exame da política monetária aplicada sob a vigência de um regime de metas de inflação.

Tal regime constituiria um "policy framework, cuja maior vantagem é a maior transparência e coerência da política, e na qual ações de política monetária bastante flexíveis, mesmo ‘discricionárias', podem ser acomodadas.” (Bernanke; Mishkin, 1997, pp.2) Desta forma, os autores, participantes principais no debate que deu origem ao sistema de metas, procuram mostrar que tal regime, ao invés de ser caracterizado pela adoção de uma regra rígida praticamente eliminando qualquer decisão de política, se constituiria numa estrutura dentro da qual uma 'discreção restringida' poderia ser exercida.

Após esta qualificação, discutiremos mais detalhadamente o sistema de metas, dada sua importância particular considerando que ele tem pautado a definição da política monetária seguida no Brasil. Este sistema pode ser caracterizado, entre outros, pelos seguintes pontos principais (Arestis et al, 2006):

- Um alvo numérico explícito em relação a uma meta de inflação, que pode ser um ponto ou uma banda mais ou menos larga, para um ou, normalmente, vários anos, é publicamente anunciado, e ações são previstas para o caso de as metas não serem atingidas.

- Reconhece-se que o objetivo principal da política monetária é o controle dos preços, através da manutenção de uma taxa de inflação baixa e estável. Sendo este objetivo alcançado, ele pode vir acompanhado pela estabilização do produto como objetivo secundário. 
- A política monetária é tomada como o principal instrumento da política macroeconômica. De fato, o dinheiro é visto como o determinante mais direto da inflação. A política fiscal não mais é considerada como instrumento efetivo, dadas a incerteza e lentidão envolvidas em sua aplicação e em seus efeitos, especialmente quando comparada à política monetária. Dentre os instrumentos de política monetária, o principal, quando não praticamente o único, é o controle das taxas de juro nominais de curto prazo.

- A política monetária não deve ser operada por políticos mas por tecnocratas, mais eficientes e que não seriam tentados a usar a política monetária de forma a obter ganhos de curto prazo à custa dos objetivos de prazo mais longo. Para garantir isto, o Bacen deveria preferivelmente desfrutar de um status independente, certamente em relação à definição e manejo dos instrumentos de política, e eventualmente também quanto à definição dos alvos a serem perseguidos.

- A operação do regime deve se pautada pela abertura e transparência (de Mendonça, 2005), através de freqüentes publicações e comunicados com a imprensa - divulgando não somente suas decisões, mas também a concepção do Bacen acerca do funcionamento da economia, os objetivos de política, os métodos para atingi-los, seus diagnósticos e previsões acerca do futuro, assim como os modelos, incluindo a inflação e outras variáveis consideradas relevantes, utilizados para analisar e implementar a política (Blinder, 2001) - , e pelo que tem sido chamado de accountability, a capacidade que as autoridades monetárias devem ter de defender e justificar perante a sociedade suas ações e os resultados obtidos, podendo ser por ela cobrados por isso. Tal política tenderia a melhorar a comunicação entre os policymarkers e o mundo dos negócios e o público em geral, reduzindo a incerteza sobre as preferências e aumentando a compreensão e previsibilidade das ações do Bacen, fundamental para aumentar e manter a credibilidade.

- A construção e manutenção da credibilidade é um ponto chave que condiciona em boa medida o sucesso da política, dada sua importância ao afetar diretamente a efetividade da política monetária e reduzir os custos da estabilização. Em países com histórico de alta inflação, em que a conquista de credibilidade é uma tarefa mais trabalhosa, ela seria especialmente importante. 
- Numa economia aberta, as considerações relativas à taxa de câmbio podem ser fundamentais, eventualmente sugerindo a adoção, especialmente em economias emergentes, de metas cambiais específicas.

Assim caracterizado, mas como ênfases e combinações algo distintas dependendo do caso, o regime de metas de inflação tem sido adotado nos últimos anos em número crescente de países, desenvolvidos ou em desenvolvimento, caracterizando-se como parte importante do consenso macroeconômico acima mencionado no que se refere à sua aplicação prática na definição de políticas. Como acima apontado, o Brasil é um destes casos, tendo adotado o regime em meados de 1999 e, também segundo Arestis et al e como pode ser percebido ao analisar alguns dos trabalhos iniciais apresentados pelo Bacen (Bogdansky et al, 2000), com a particularidade de que as autoridades brasileiras teriam aderido de maneira entusiasta a seus princípios teóricos.

Apesar deste entusiasmo por parte dos policymakers brasileiros, dúvidas quanto à adequação e eficiência do regime para o caso de países contendo características similares ao Brasil têm sido freqüentemente colocadas. No estudo de Eichengreen (2002), por exemplo, apontam-se as dificuldades eventualmente importantes enfrentadas por países emergentes ao implementar regimes de metas de inflação. Estas dificuldades estariam ligadas, segundo esse estudo, basicamente a três características destas economias: abertura, que exporia esses países a maior vulnerabilidade a choques externos, além de tornar os canais de transmissão da política monetária relacionados ao câmbio relativamente mais importantes; dolarização de passivos, fazendo com que eventuais flutuações do câmbio próprias ao regime levem à desestabilização dos balanços das empresas e instituições financeiras; e falta de credibilidade, que imporia pesados custos em termos de crescimento econômico devidos à rigidez exigida na aplicação das políticas, justamente aos países que mais necessitariam de uma maior flexibilidade, dadas suas características, nessa aplicação. Esta combinação entre vulnerabilidade externa, fragilidade financeira e rigidez na aplicação da política poderia conduzir mais facilmente a ataques especulativos e crises financeiras, dificultando o ganho de credibilidade necessário. Por outro lado, o efeito das taxas de juro, instrumento principal do regime de metas de inflação, atuando fundamentalmente sobre o lado da demanda, podem não ser tão efetivo em países especialmente sujeitos a choques externos. Dificuldades adicionais relativas ao grande peso dos preços backward-looking na inflação, os quais são insensíveis a choques nos juros, fazendo com que estes devam ser mais elevados de maneira a manter os preços livres abaixo 
da meta de inflação, e ao risco da introdução de ruídos desnecessários devido à freqüência trimestral, em vez de anual - com que é feito o monitoramento das taxas de inflação no caso em que o país estivesse no quadro de um programa do FMI em andamento, são por sua vez discutidas no trabalho de Bogdanski et al (2001).

Já em relação aos resultados empíricos que têm sido alcançados por países que aderiram ao MI, também existem controvérsias. Arestis et al (2006), por exemplo, encontram que a adoção de MI por parte de países emergentes não teria sido um elemento significativo na queda verificada em seus níveis de inflação, uma vez que este teria sido um fenômeno generalizado entre os países selecionados, tanto entre os que adotaram quanto os que não adotaram MI; além disso, não encontram evidências de que países que adotaram MI teriam melhorado seu desempenho em termos de produto quando comparados a países que não adotaram esse regime. Eles concluem, portanto que outros fatores seriam responsáveis pelas melhoras alcançadas. Para o caso particular do Brasil, as evidências seriam ainda menos favoráveis às MI, já que mesmo após a adoção do regime seguindo a teoria, as taxas de inflação continuariam elevadas apesar das taxas de juros entre as mais elevadas do mundo, e o crescimento seria baixo. O trabalho de Sicsú (2002a) aponta também para a falta de evidências em relação à eficiência do regime de metas em reduzir a inflação durante a década de 1990. Por outro lado, o estudo de Gonçalves (2005) seguindo, para o caso de países emergentes, a análise usada por Ball e Sheridan (2003), os quais não teriam encontrado evidências de que a adoção do regime de MI em países desenvolvidos seria instrumental na queda no nível e na volatilidade da inflação, sugere que, pelo contrário, no caso de países emergentes a adoção de MI não somente teria provocado quedas maiores na inflação, como teria também reduzido a volatilidade do produto. Diferenças nos países escolhidos para a amostra assim como a possível ausência de variáveis de controle relevantes estão possivelmente entre os responsáveis de tão díspares conclusões. Seja como for, o que parece evidente é que a verificação empírica da conveniência e relevância do regime de metas de inflação permanece ainda como um tema controverso.

\section{O Modelo Estrutural}

Na seção anterior, indicamos que a política monetária seguida no Brasil teria basicamente estado em concordância com os conceitos que fazem parte do que foi acima denominado, 
seguindo Piza e Dias, de novo consenso macroeconômico. Por outro lado, foi apontada a adoção pelo Brasil do regime de metas de inflação, o qual pode ser considerado uma derivação natural deste consenso, e foram discutidas algumas de suas características principais. Entretanto, até o momento não identificamos, a partir das características deste consenso, os elementos que nos permitissem explicar as excepcionais taxas reais de juro verificadas no Brasil. Portanto, continuaremos investigando a seguir estas características. Para tanto, discutiremos de forma um pouco mais detalhada o modelo macroeconômico estrutural que tem pautado as decisões relativas à condução da política monetária no Brasil desde a implementação do sistema de metas de inflação.

Este modelo, no caso do Brasil, embora estando muito próximo do modelo acima discutido, apresenta algumas particularidades, a principal das quais se refere à presença de uma quarta equação que procura integrar explicitamente a taxa de câmbio em sua dinâmica. Assim, o modelo utilizado pelo Bacen é estruturado a partir das quatro equações apresentadas a seguir. (Bogdansky et al, 2000)

- Uma curva do tipo IS, representada como:

$$
h_{t}=\beta_{0}+\beta_{1} h_{t-1}+\beta_{2} h_{t-2}+\beta_{3} r_{t-1}+\varepsilon_{t}^{h},
$$

onde $h_{t}$ é o hiato do produto (normalmente incluído em $\log$ ), que aparece como função de suas próprias defasagens, da taxa real de juros defasada (ex-ante ou ex-post), $r_{t-1}$, e de choques de demanda. Além dessa versão básica, afetando o hiato do produto pode ser incluída a taxa de câmbio real e, por exemplo, se o impacto do déficit público for visto como particularmente relevante e o governo se comprometesse com seu controle, variáveis relacionadas à política fiscal também podem fazer parte desta equação de forma a tomar explicitamente em conta sua influência no modelo.

- Curva de Phillips, expressando a taxa de inflação $\left(\pi_{t}\right)$ como:

$$
\pi_{t}=\alpha \pi_{t-1}+\beta E_{t}\left(\pi_{t+1}\right)+\gamma h_{t-1}+\lambda \Delta\left(p_{t}^{F}+e_{t}\right)+\varepsilon_{t}^{f}
$$


ou seja, em função de distintas combinações de suas próprias defasagens (visão backwardlooking) e das expectativas de inflação para o futuro (forward-looking), além do hiato do produto, da taxa de câmbio real (incluída na equação acima como a diferença da soma dos $\log s$ do índice de preços no exterior e da taxa de câmbio nominal), e de choques nas expectativas. Além disso, é imposta a condição de neutralidade a longo-prazo.

- Uma equação representando a paridade descoberta da taxa de juros discutida no capítulo anterior, relacionando o diferencial entre as taxas de juro domésticas e internacionais à taxa esperada de desvalorização da moeda mais um termo relacionado ao prêmio de risco. A determinação do prêmio de risco pode ocorrer de forma endógena ao incluir no modelo as variáveis que se acredita o afetam.

- Uma regra de taxa de juros - a função de reação -, relacionando variáveis escolhidas dentro do modelo às taxas de juro de curto prazo definidas pelo Bacen.

A partir deste modelo estrutural, simulações são realizadas utilizando hipóteses consideradas como as mais prováveis pelos formuladores de política assim como cenários alternativos em que aquelas hipóteses seriam violadas, de forma a gerar previsões da inflação e do produto, da trajetória da taxa de juros, e a verificar o comportamento dessas e de outras variáveis relevantes face à ocorrência de choques exógenos. De posse dos resultados obtidos a partir destas simulações, tornar-se-ia possível a visualização dos mecanismos de transmissão da política monetária implícitos no modelo e, com estas informações, combinadas com aquelas colhidas de outras fontes, particularmente de surveys nos mercados e expectativas implícitas em instrumentos financeiros, além dos resultados obtidos por modelos VAR de curto prazo também construídos pelo próprio Bacen, seriam tomadas as decisões referentes à execução da política monetária, as quais se referem fundamentalmente à definição da meta da taxa de juros nominal de curto prazo.

\section{A Função de Reação}

A taxa de juros nominal que surge como resultado do equilíbrio no modelo estrutural acima apresentado, poderia ser diretamente obtida se pudéssemos estimar a última das equações que fazem parte desse modelo, a função de reação do Bacen. De fato, estas taxas poderiam ser 
simplesmente explicadas a partir dos parâmetros implícitos no funcionamento dessa função, os quais indicariam, portanto, as variáveis relevantes nesta definição, questão no qual estamos realmente interessados.

Entretanto, para que isso fosse possível, deveríamos considerar essa forma funcional como efetivamente representando uma relação estrutural - portanto invariante a mudanças de política -, a qual explicaria o comportamento do Bacen como dependendo inequivocamente de modificações ocorridas em variáveis determinadas constantes da função. Ou seja, esta função não poderia apenas representar uma forma reduzida, que incorpora um amálgama de relações estruturais não somente relacionadas ao Bacen, mas também aos demais agentes da economia, caso no qual não explicaria verdadeiramente seu comportamento, ao não distinguir claramente entre as ações deste e o resultado composto das ações do conjunto dos agentes, gerando um viés de simultaneidade na estimação. (Hetzel, 2000) Nos trabalhos práticos, contudo, em que a função de reação é normalmente estimada de forma direta e independentemente do modelo macroeconômico a ela associada, assume-se tratar-se ela de fato de uma relação estrutural. Ao proceder desta forma, aumenta-se sobremaneira a facilidade com que se constroem previsões relativas à evolução futura da taxa de juros; no entanto, fica-se sujeito a importantes críticas que questionam a validade de uma função assim estimada ao efetuar previsões ou verificações empíricas no caso da ocorrência de mudanças de política.

Após esta importante qualificação, considerando que a função de reação do Bacen, tomada isoladamente ou como parte de um modelo macroeconômico estrutural, é uma das relações mais estudadas e estimadas na área de política monetária, e que, no caso de encontrarem-se nos requisitos da política monetária os determinantes fundamentais das taxas reais de juros, ela concentraria as informações nas quais estamos interessados neste trabalho, vemos a conveniência em estudar esta função de forma mais detalhada, o que faremos a seguir.

De fato, a função de reação identificaria justamente as variáveis incluídas no modelo acima discutido cuja evolução seria tomada em consideração pela política monetária, na definição das taxas de juros fixadas pelo Bacen; dessa forma, seríamos capazes de identificar os determinantes de suas flutuações, embora não obtenhamos, necessariamente, indicativos relevantes para a explicação dos níveis em torno dos quais tais flutuações ocorrem. Veremos a seguir se esta análise efetivamente nos leva a soluções satisfatórias nesse sentido. 
Existe uma grande variedade de especificações que a função de reação do Banco Central pode assumir, embora a grande maioria delas siga o modelo original de Taylor (1993) no que se refere à sua especificação na forma linear. Também como proposto nesse modelo, a função é normalmente apresentada a partir da seguinte configuração básica:

$$
i_{t}=\alpha_{t}+\lambda_{1} \pi_{t}+\lambda_{2} x+i_{t-1}
$$

relacionando a variável dependente, os juros nominais $\left(i_{t}\right)$, a duas variáveis explicativas, a inflação $\left(\pi_{t}\right)$ e o hiato do produto $\left(x_{t}\right)$, cujos coeficientes indicariam a importância relativa que cada variável possui entre os objetivos definidos pelo Bacen, além de um termo relativo ao intercepto e outro representando a inércia da política monetária. Mesmo não apresentando exatamente a especificação original, funções deste tipo são normalmente referidas de um modo geral na literatura como regra de Taylor. A diversidade de especificações em que ela se apresenta refere-se principalmente (mas não exaustivamente):

- à escolha da maneira de considerar as variáveis, tanto as explicativas como a variável dependente, se em níveis, diferenças, ou como desvios em relação a valores definidos (meta de inflação, produto potencial);

- à utilização das variáveis explicativas com seus valores contemporâneos ou em defasagens;

- à inclusão de outras variáveis-objetivo na própria função, como por exemplo, a taxa de câmbio;

- à introdução do termo de suavização, tornando o ajustamento gradual;

- ao conceito de inflação a ser usado, se inflação passada (backward looking) ou expectativas de inflação futura (forward looking), ou a uma composição de ambos;

- à estabilidade dos parâmetros e do intercepto, constantes ou variáveis no tempo.

Dependendo da configuração escolhida, os resultados obtidos em distintas estimações podem ser significativamente diferentes, fazendo com que esta questão seja fonte de abundante debate e deva ser efetivamente analisada com cuidado em trabalhos empíricos.

Embora simples, o que facilita enormemente sua utilização, considera-se (Freitas; Muinhos, 2001) que a estimação de uma função deste tipo apresenta, dependendo dos parâmetros utilizados, resultados tão satisfatórios em termos de variância da inflação e do hiato do 
produto quanto funções bem mais sofisticadas derivadas diretamente da otimização de uma função perda do Banco Central (Woodford, 2003), fato que tem contribuído para popularizar sua utilização na análise da política monetária.

Nos últimos anos, tem-se empreendido considerável esforço no âmbito acadêmico discutindo e procurando estimar a partir dos dados empíricos obtidos ex-post a função de reação que teria sido ou estaria sendo utilizada pelo Bacen no Brasil. Isto não implica necessariamente que deveria ser possível encontrar uma função que fosse capaz de explicar a totalidade dos movimentos da taxa de juros meramente a partir de suas variáveis explicativas, inclusive porque dificilmente o Bacen executaria sua política monetária seguindo de forma automática as prescrições resultantes de uma função. Entretanto, dado que o modelo geral usado pelo Bacen é por ele divulgado e, portanto conhecido, e que uma das recomendações importantes do regime de MI constando das diretrizes de sua atuação é justamente fomentar a previsibilidade de suas ações, uma função de reação estimada adequadamente pode efetivamente fornecer importantes indicativos de quais seriam as variáveis relevantes sendo tomadas em consideração para a definição da política monetária adotada. Neste sentido, comentaremos a seguir alguns trabalhos que justamente têm buscado realizar essa estimação. Considerando que os trabalhos aqui discutidos são bem recentes, aproveitam os resultados de abundante pesquisa empírica internacional realizada desde a proposição original da regra de Taylor, o que os leva a usar modelos mais sofisticados que resolvem alguns dos problemas encontrados nas primeiras estimações.

Minella et al (2003), com dados entre 1999 e 2002, portanto, relativos ao início do regime de metas, estimam a função de reação do Bacen relacionando as taxas de juros aos desvios das expectativas de inflação em relação à meta, ao hiato do produto, a um coeficiente de persistência e à variação cambial, com variantes excluindo o hiato e a taxa de câmbio. As expectativas de inflação usadas são obtidas de duas fontes: as previsões de inflação publicadas no Relatório de Inflação do Bacen, e as previsões recolhidas em surveys realizados pelo Bacen junto a instituições financeiras e firmas de consultoria. Os resultados obtidos pelo trabalho para o modelo completo mostram a existência de um elevado coeficiente de persistência $(0,77$ e 0,67 , para as expectativas segundo o Relatório de Inflação ou os surveys de mercado, respectivamente), mostrando um elevado gradualismo no ajuste dos juros. Os coeficientes dos desvios das expectativas de inflação, por sua vez, dado seu elevado valor 2,7 e 2,1, respectivamente, segundo o caso - , portanto bem acima de um, mostram que a 
regra de política monetária seguida no Brasil tem reagido fortemente a esses desvios e tem contemplado o princípio de Taylor (segundo o qual a variação na taxa de juros definida pelo Bacen em resposta às mudanças na inflação deveria ser mais do que proporcional - o coeficiente relacionado à inflação deveria ser maior do que um - , caso contrário verificar-seia uma tendência à trajetória instável da inflação e à ineficiência da política; Woodford, 2003) na regra de política adotada no Brasil. Por outro lado, os coeficientes relativos ao hiato do produto e à taxa de câmbio são em geral não significativos e de valores muito baixos.

Seguindo Clarida et al (2000), que argumentam que o parâmetro relativo à inflação pode variar em função dos conhecimentos adquiridos pelos mercados e pelos formuladores de política dependendo do período da amostra, Bueno (2005) estima a função de reação do Banco Central para o Brasil utilizando um regime de Markov Switching, o qual estima de forma endógena ao modelo econométrico os distintos regimes pelos quais a política monetária teria passado, o que parece adequado ao estudo do caso do Brasil, que passou nas últimas décadas por significativas modificações na condução da política econômica. De fato, os resultados da estimação apontam para a variação do parâmetro da inflação e a existência de três regimes distintos, de alta inflação, de transição, e pós-estabilização. Utilizando a taxa de inflação efetiva em níveis em vez de desvios das expectativas da meta, o coeficiente da inflação encontrado é normalmente menor do que um ou insignificante, assim como o do hiato do produto, enquanto que o coeficiente sobre a defasagem da taxa de juros, introduzido procurando verificar a eventual suavização do ajuste, é aqui também elevado e significativo, indicando modificações graduais nas taxas de juro.

Na mesma direção, Policano e Bueno (2006) estimam a função de reação pelo método Time Varying Parameters, que permite a variação dos coeficientes da função período a período, e incluem outras variáveis objetivo na função. Pelos resultados obtidos, a condução da política monetária desde 1995 se dividiria em dois regimes distintos, sendo que o primeiro correspondente ao período de câmbio administrado que vigorou até 1999, enquanto o segundo é o que teria vigorado desde então. No primeiro regime, a taxa de juros teria reagido fortemente às variações nas reservas cambiais do Banco Central, o que se justificaria num regime de câmbio fixo, reação que diminui até atingir níveis muito baixos após a adoção do regime de MI. Para o segundo regime, em que vigoram as metas de inflação, ao usar diretamente a inflação como variável relevante, o coeficiente estimado seria, como no estudo de Bueno, menor do que um, o que caracterizaria a violação do princípio de Taylor. 
Entretanto, quando a taxa de inflação é substituída pelo desvio das expectativas de inflação (coletadas a partir de surveys em mercados financeiros realizados e divulgados pelos Gerin/Bacen) em relação à sua meta, o coeficiente obtido é sempre - com a exceção dos meses de maio e junho de 2001, logo após a deflagração da crise energética - maior do que 1 , satisfazendo aquele princípio, e oscilando na maior parte do tempo em torno de 1,5, apesar de incluir um período consideravelmente longo alcançando valores maiores, em torno de 2,5, desde o início do novo governo em 2003, até finais de 2004. O coeficiente do hiato do produto, por sua vez, após iniciar, no começo do regime, com valores próximos a 0,7 , se estabiliza em 2002 e 2003 em valores próximos a 0, para posteriormente voltar a subir, embora a níveis baixos, próximos a 0,2. Já o coeficiente do intercepto na equação, que identifica outras variáveis afetando a taxa de juros não incluídas na função, não só é significativo como assume elevados valores; de fato, após diminuir a partir de níveis iniciais muito elevados, acima de 30\%, verificados no começo do Plano Real, a partir do segundo semestre de 2000 se estabiliza entre 15 e $20 \%$. Por sua vez, o coeficiente de persistência dos juros também aqui é elevado, flutuando em torno de 0,75 . Finalmente, a resposta a variações no câmbio neste trabalho, especialmente após a implementação do regime de MI, também se mostrou muito baixa, com valores sempre próximos a zero.

Já o trabalho de Holland (2005) estima, com dados entre 1999 e 2005, a função de reação usando como variáveis explicativas a expectativa de inflação (não o desvio em relação à meta) e o hiato do produto e as taxas de câmbio nominal real. Os resultados apontam, aqui também, para uma forte reação dos juros a mudanças nas expectativas de inflação, apesar de que o coeficiente estimado é altamente sensível ao método usado para calcular a série do produto potencial, se o filtro HP ou uma tendência linear; esta reação seria particularmente forte quando comparada à verificada em outros países. O coeficiente sobre o hiato do produto apresenta valores muito menores do que o coeficiente de inflação, menor nível de significância, e sinal contrário ao esperado pela teoria (negativo), o que Holland justifica pelos efeitos de choques de oferta, principalmente durante a crise energética de 2001, que teriam ocorrido durante o período. Já o coeficiente sobre o câmbio real não é significativo, enquanto sobre o câmbio nominal ocorre o contrário; tal fato pareceria indicar, segundo o autor, que preocupações quanto a depreciações nominais que pudessem provocar instabilidade financeira são mais importantes para explicar a atuação do Bacen do que a ocorrência de desalinhamentos cambiais permanentes. 
O último trabalho que comentaremos aqui brevemente é o de Teles e Brundo (2006), que estimam a função de reação do Bacen utilizando, além das medidas mais convencionais, medidas qualitativas, baseadas na análise das atas do Copom, para aferir o comportamento da política monetária, de forma a supostamente isolar os impactos de choques monetários das variações na taxa natural de juros. Os resultados aqui encontrados são consistentes com os encontrados nos trabalhos acima, apontando para coeficientes significativos e elevados para a inflação (e mais elevados a partir de 2003), e não significativos para o hiato do produto.

Finalmente, seguindo as conclusões dos trabalhos acima, podemos encontrar um último indicativo da importância das expectativas de inflação para explicar as decisões tomadas pelo Bacen ao calcular o coeficiente de correlação entre essas expectativas e as taxas de juros. De fato, ao fazer isso, encontramos que o coeficiente de correlação verificado entre a meta mensal da taxa Selic e a média mensal das expectativas de mercado colhidas pelo Gerin/Bacen quanto ao IPCA 12 meses à frente é de 0,78; quando a média das expectativas é defasada em um período, o coeficiente de correlação é inclusive maior, de 0,83. Apesar de não indicar causalidade, estes valores elevados apontam para uma forte relação existente entre as duas variáveis.

Da análise das evidências apresentadas nos trabalhos acima discutidos para o caso do Brasil, quatro pontos em especial merecem nossa atenção:

- Dentre as variáveis normalmente consideradas como relevantes, o principal determinante das alterações promovidas pelo Bacen na taxa de juros parece ser o desvio das expectativas de inflação em relação à meta escolhida. Considerando que esta meta é fixa para cada ano, as variações nos juros seriam então essencialmente determinadas por mudanças verificadas nas expectativas de inflação.

- Os efeitos individuais de variações no hiato do produto e no câmbio são pequenos, e quase sempre não significativos. Isto nos leva a crer que somente afetariam as taxas de juro na medida em que fossem capazes de afetar as expectativas de inflação.

- A manutenção ao longo do tempo de um intercepto muito elevado indica que a reação do Bacen à variação em variáveis normalmente consideradas, incluindo as expectativas de inflação, que está expressa nesta função, apesar de poder explicar de forma razoavelmente 
satisfatória as variações ocorridas, são capazes de explicar apenas parcela bastante limitada do nível da taxa de juros efetivamente praticada.

- O coeficiente de suavização dos juros é normalmente bastante elevado, indicando um ajuste gradual das taxas de juro.

Como conclusão para esta seção, retemos, particularmente, a constatação do papel assumido pelas expectativas de inflação como determinante principal no processo de fixação das taxas nominais de juro por parte do Banco Central; variáveis econômicas reais somente teriam efeito sobre as taxas de juro na medida em que fossem capazes de afetar estas expectativas. Esta resposta, entretanto, não nos é suficiente para entender como são determinadas as taxas de juros efetivamente observadas, uma vez que as expectativas, longe de serem um dado que se refere diretamente aos fundamentos da economia, são, idealmente, apenas função destes fundamentos. Se quisermos entender como se dá aquela determinação, devemos, portanto investigar os fatores que estão por trás da formação destas expectativas, o que será feito na próxima seção.

\section{Determinantes das expectativas de inflação}

Após verificar que as expectativas de inflação constituem o elemento principal da explicação das variações nas taxas de juros definidas pelo Bacen, a resposta à questão de quais seriam os determinantes destas taxas somente pode ser fornecida de forma satisfatória, como vimos, se encontrarmos os determinantes daquelas expectativas.

Existem vários fatores que têm sido considerados como normalmente influenciando o processo de formação das expectativas de inflação. Um deles que, como veremos adiante, tem resultado ser empiricamente o mais relevante, se refere, num sistema de metas de inflação, justamente às próprias metas fixadas pelo Governo. Sua importância relativa dependeria fundamentalmente da credibilidade das metas de inflação, o que seria por sua vez função da percepção dos agentes econômicos em relação ao compromisso e à capacidade do Governo em geral e da política monetária em particular de atuar consistentemente e impor à economia o cumprimento das metas fixadas; quanto maior a credibilidade alcançada, maior seria a importância das metas de inflação na formação das expectativas, e menores seriam os custos 
associados ao controle da inflação. No limite, inclusive, numa hipotética situação de ausência de rigidez nominal de preços num regime de metas desfrutando de total credibilidade, a convergência da inflação verificada em direção à meta estabelecida se daria unicamente através do ajuste nas expectativas.

Procurando investigar esses fatores, Minella et al (2003) estimam, com dados disponíveis apenas até o início de 2003, uma função em que as expectativas de inflação 12 meses à frente são confrontadas a suas próprias defasagens, à meta de inflação, a taxa de juros, e a inflação dos 12 últimos meses. Os resultados obtidos apontam que os coeficientes de todas as variáveis são significativos, e o relativo à meta de inflação, próximo de um, é o mais elevado dentre eles; além disso, o coeficiente de persistência da inflação, que indica a importância da inflação passada na definição da inflação corrente, teria significativamente diminuído. Somado a este estudo, os autores apontam para o fato de que, até o último trimestre de 2002, as expectativas de inflação haviam permanecido abaixo do limite de tolerância fixado pela meta e se situavam também abaixo da inflação passada, o que indicaria uma convergência futura em direção à meta. Assim, eles concluem que até fins de 2002 as metas de inflação teriam funcionado como importante fator de coordenação das expectativas e, após isso, a elevação das expectativas acima da meta seria característica de um período particular de transição; esse desvio em relação à meta não teria, portanto ocorrido devido à falta de credibilidade na condução da política seguida na época, credibilidade que teria aumentado significativamente desde a adoção do regime de metas, mas pela incerteza em relação à sua manutenção no novo governo.

No trabalho de Alves e Aerosa (2005), uma equação para as expectativas de inflação é derivada a partir de uma curva de Phillips Novo-Keynesiana relacionando a inflação corrente ao hiato do produto e às expectativas de inflação; tal especificação puramente forwardlooking é complementada ao considerar que uma determinada parcela das firmas na economia reajustaria seus preços baseadas na inflação passada, introduzindo assim um elemento backward-looking na determinação da dinâmica inflacionária. Posteriormente, ao modificar a especificação para um regime de MI, o componente da inflação passada na determinação dos preços de uma parcela das firmas é substituído por uma média ponderada entre essa inflação e a meta de inflação, assumindo que esta teria pelo menos algum grau de impacto na determinação dos preços. Finalmente, são introduzidos os custos marginais, estimados a partir de uma função de produção, e a variação cambial, como fator que, ao afetar os preços de 
parcela dos bens consumidos internamente, afeta a taxa de inflação. Após todas estas considerações, fazendo as necessárias manipulações algébricas e calculando recursivamente, obtemos uma equação que explica as expectativas de inflação $\left(E \pi_{t+1}\right)$ como:

$$
\begin{aligned}
E_{t} \pi_{t+1}=(1-\lambda)^{2} \pi_{t-1}+\lambda(1-\pi) \pi_{t}^{0}+\lambda \pi_{t+1}^{0}+(1-\lambda)\left[\frac{\delta}{1-\delta} \Delta q_{t}+\kappa x_{t}\right]+ \\
+\left[\frac{\delta}{1-\delta}\right] E_{t} \Delta q_{t+1}+\kappa\left(1-\lambda+\beta^{-1}\right) E_{t} \sum_{j=1}^{\infty} \beta^{j} x_{t+j},
\end{aligned}
$$

dependendo, portanto das seguintes variáveis:

- inflação passada;

- meta de inflação $\left(\pi^{0}\right)$ para os períodos corrente e futuro;

- taxa de depreciação real da moeda $\left(\Delta q_{t}\right)$;

- hiato do produto corrente $\left(x_{t}\right)$;

- expectativa em relação aos hiatos futuros do produto;

e dos parâmetros:

- peso da meta de inflação em relação à inflação passada $(\lambda)$;

- peso dos produtos importados nas cestas de consumo $(\delta)$;

- importância relativa do hiato do produto na inflação $(\kappa)$.

Assim, as expectativas de inflação dependeriam positivamente da inflação passada, das metas de inflação, do hiato do produto corrente, da variação cambial corrente e dos custos marginais, e das expectativas futuras em relação ao hiato do produto e à variação cambial. Numa situação em que o coeficiente do peso relativo da meta de inflação na determinação da inflação corrente $(\lambda)$ fosse igual ou muito próximo a um, as expectativas de inflação não dependerão da inflação passada, do hiato do produto corrente nem de variações cambiais, mas apenas da meta de inflação, e das expectativas em relação ao hiato e ao câmbio real. Ou seja, em tal situação, e se estas expectativas considerarem o hiato do produto e o câmbio como flutuando em torno a suas trajetórias de equilíbrio - hipótese freqüentemente assumida -, a determinação das expectativas de inflação repousaria exclusivamente nas metas de inflação 
definidas pelo Governo, que seriam então os determinantes dessas expectativas. Quanto mais afastado da unidade esse coeficiente for, o efeito contrário ocorrerá, ou seja, menor será a importância da meta de inflação na determinação das expectativas de inflação.

Procurando estimar empiricamente a função acima descrita, o trabalho de Alves e Aerosa divide o período desde a implementação do regime de metas de inflação em três fases, nas quais a evolução do coeficiente relativo ao peso da meta de inflação teria sido diferente. $\mathrm{Na}$ primeira, entre 1999 e 2000, o coeficiente $\lambda$ teria aumentado de 0,50 no início do regime até 0,75 no final de 2000, mostrando o rápido aumento de sua importância. Na segunda fase, entre 2001 e 2002, apesar da ocorrência de importantes choques, tanto internos quanto externos, afetando a economia, o coeficiente $\lambda$ se mantém na maior parte do período em níveis elevados: flutua entre 0,75 , valor válido no final de 2001 , e quase 1 , valor alcançado em meados desse ano, para em 2002 colapsar de 0,90, no meio do ano, até 0,25 no quarto trimestre. Finalmente, a terceira fase, que se inicia em 2003, assiste à recuperação do parâmetro relativo à meta de inflação, que se eleva até atingir 0,75 no final de 2004. Quando os resultados da regressão são analisados em sua totalidade, sem esta divisão em subperíodos, os únicos coeficientes que aparecem como significativos são os referentes à meta de inflação e, embora apresentando valor muito menor, também o relativo ao câmbio. De uma forma geral, os resultados deste trabalho apontam de forma bastante clara que, com exceção do período de aproximadamente um ano começando no último trimestre de 2002, o coeficiente que representa o peso da meta de inflação na determinação da inflação corrente tem sido elevado, assinalando a relevância desta meta na determinação das expectativas de inflação.

Além da consistência da condução da política monetária com a manutenção do regime de metas, e da adoção de uma política clara e transparente de comunicação, um elemento que tem sido freqüentemente colocado como especialmente relevante para ganhar e manter a credibilidade refere-se à postura fiscal do Governo. Nesta visão, a adoção de uma política fiscal conservadora, reduzindo o impacto dos gastos públicos na demanda agregada e assim na inflação, sinalizaria o compromisso com a meta inflacionária fixada, aumentando a credibilidade do regime. Estudo com objetivo semelhante ao do trabalho anterior mas introduzindo explicitamente a política fiscal no modelo é feito por Cerisola e Gelos (2005), que estimam, usando três métodos distintos (GMM, OLS e FMOLS), uma equação em que as expectativas de inflação aparecem como função novamente da inflação passada e da meta de 
inflação, mas também dos custos marginais reais, aproximados pelos desvios da taxa real de câmbio e dos salários reais em relação a seus valores tendenciais. Além dessas variáveis, como dissemos, o trabalho considera explicitamente a política fiscal como elemento importante afetando as expectativas de inflação; de fato, a inflação não somente receberia o impacto do déficit fiscal corrente, mas seria também afetada pela trajetória futura da situação fiscal, que afetaria as expectativas de inflação; para tomar esta variável em consideração, o déficit (superávit) público sobre o PIB é também incluído como outra variável na estimação. Finalmente, e como forma de aferir a instância da política monetária, é incluída uma variável representando as taxas reais de juro. Os resultados da estimação apontam para a relativamente reduzida importância da inflação passada, com coeficientes variando entre 0,18 e 0,29 dependendo do método de estimação. Por outro lado, a meta de inflação apresenta coeficientes significativamente maiores, entre 0,66 e mesmo 1, que corresponderia, num modelo com preços flexíveis formados de forma forward-looking, a uma meta de inflação totalmente crível. Outro resultado aponta para a importância da situação fiscal, apresentando um coeficiente significativo de $-1,05$, o que indica que um aumento no superávit fiscal levaria a uma diminuição proporcional nas expectativas de inflação. Por outro lado, tanto a taxa de câmbio como os salários reais apresentam coeficientes significativos e positivos, embora com valores relativamente baixos (em torno de 0,10 e 0,20 respectivamente), indicando a pertinência de sua inclusão na regressão. Finalmente, no caso das taxas reais de juro, os coeficientes encontrados para as taxas defasadas não são significativos, aparentemente indicando a falta de relevância, pelo menos de forma direta, desta variável na definição das expectativas de inflação. Ao estimar recursivamente o modelo, o que permite a observação de eventuais modificações que teriam ocorrido nos parâmetros ao longo do tempo, verificamos a delimitação de três períodos distintos, dentro dos quais a relevância das metas de inflação na definição das expectativas varia de maneira muito próxima ao que pôde ser concluído a partir do trabalho de Alves e Aerosa:

- No primeiro período, desde a implementação do sistema de metas até o início de 2002, o regime parecia desfrutar de grande credibilidade, e o coeficiente da meta de inflação era muito relevante.

- Numa segunda etapa, confrontadas a importantes choques internos e externos, as metas de inflação parecem ter significativamente perdido credibilidade; nessa situação, o coeficiente relativo às metas diminui muito seu valor e elas não parecem jogar um papel importante na 
definição das expectativas; a inflação passa então a assumir um caráter mais fortemente backward-looking. Nessa situação, a instância fiscal parece ganhar maior importância na definição das expectativas, embora o período em que isso ocorreria seja muito específico e de curta duração. Esta caracterização é particularmente adequada ao período que se inicia no final de 2002 e se estende durante a primeira metade de 2003, período no qual persistiam fortes dúvidas quanto à manutenção do compromisso com as metas de inflação por parte do novo governo.

- No último período, iniciando-se em 2003 mas com os resultados mais claros aparecendo em 2004, o compromisso demonstrado pelo governo em relação ao regime de metas tem levado ao aumento de sua credibilidade e feito com que as metas de inflação tenham voltado a desempenhar papel fundamental na ancoragem das expectativas de inflação.

Da análise dos trabalhos acima examinados, podemos reter como conclusão principal que as expectativas de inflação têm sido, em boa medida, determinadas pelas próprias metas de inflação fixadas pelo Governo; mesmo com a ocorrência de sucessivos choques, as metas mantiveram na maior parte do tempo a capacidade de influenciar as expectativas. E mais, os trabalhos apontam para o fato de que, excetuando o período caracterizado pela crise de confiança em relação à manutenção do regime de metas pelo novo governo, a meta de inflação não teria somente influenciado as expectativas, mas teria sido seu principal determinante. Com exceção, talvez, da instância da política fiscal, e apenas durante um período restrito, os trabalhos não encontram evidências que tragam algum outro fator, que não as metas de inflação, como sendo essencial para explicar as expectativas de inflação.

Esta conclusão, baseada em evidências obtidas através de testes empíricos, é, de fato, consistente com a teoria subjacente ao regime de metas de inflação. Efetivamente, quando alcançando sucesso em seu funcionamento, este regime leva justamente a que as metas de inflação funcionem como âncora para as expectativas. A busca deste objetivo se justifica ao considerarmos que, se os agentes econômicos são racionais e não há rigidez nominal de preços, a situação destas expectativas, ancoradas na meta de inflação, definiria direta e imediatamente a inflação verificada. E, mesmo com a ocorrência de algum grau de rigidez e havendo uma parcela importante dos agentes que reajusta seus preços de forma backwardlooking, baseados na inflação passada, se as metas desfrutam de credibilidade e afetam as expectativas de inflação da maioria dos agentes, a inflação verificada convergirá, num certo 
horizonte de tempo, em direção à meta. Se esta for fixada como baixa e estável, um regime que consiga dar credibilidade a esta meta será capaz de estabilizar a inflação nestes patamares desejados.

Assim, uma análise dos resultados alcançados pelo regime de metas no Brasil, ao constatar sua capacidade de afetar as expectativas de inflação, poderia concluir que o regime tem obtido sucesso. Contudo, resta a questão, fundamental neste trabalho, mas ainda sem resposta, que pretende verificar se realmente o funcionamento deste regime como teoricamente previsto conduziria forçosamente à vigência de taxas reais de juros especialmente elevadas, como ocorre no Brasil.

\section{Juros e Metas de Inflação}

Nesta seção, veremos se as conclusões às quais chegamos nas seções anteriores são capazes de fornecer de forma satisfatória o suporte necessário para explicar as elevadas taxas reais de juro observadas no Brasil como resultando naturalmente dos requisitos exigidos pela condução exitosa da política monetária por parte do Bacen. Neste sentido, nessas seções vimos, primeiramente, que as taxas de juros nominais (que, com a exceção dos momentos de curtos momentos de rápida aceleração inflacionária, têm determinado as taxas reais de juros) respondem fundamentalmente às variações nas expectativas de inflação, e, num segundo momento, que tais expectativas têm se pautado, em grande medida, pelas metas de inflação. Daqui, portanto, poderíamos concluir que as taxas reais de juro fundamentalmente dependem das metas de inflação fixadas pelo Governo; para alcançar as metas escolhidas exigir-se-ia a manutenção das taxas verificadas. Isto estaria de fato em linha com a idéia que atribui as elevadas taxas reais de juro diretamente às necessidades de execução da política monetária. Não se vê nesta lógica nenhuma referência explícita a considerações relacionadas a variáveis econômicas fundamentais; se existir, o eventual efeito de tais variáveis sobre as taxas reais de juro somente se materializaria por meio de sua possível influência sobre o estado das expectativas.

Entretanto, este tipo de solução não é capaz de explicar porque, no caso específico do Brasil, a busca de metas de inflação, que não são particularmente ambiciosas numa perspectiva internacional, tem exigido a manutenção prolongada de taxas reais de juro que são, nessa 
mesma perspectiva, excepcionalmente elevadas. De fato, não há nada nesta formulação que indique os patamares nos quais as taxas reais de juros deveriam necessariamente se posicionar de forma a levar as expectativas de inflação aos níveis desejados. Encontramos-nos, novamente, com uma afirmação que repete a fórmula exposta no início do capítulo e cujo conteúdo não parece muito consistente, embora aqui, graças à análise realizada nas duas últimas seções, seja colocada com um detalhamento maior: nesta fórmula, as taxas reais de juros seriam elevadas porque respondem às expectativas de inflação, as quais por sua vez estão assentadas sobre as metas de inflação escolhidas. Assim, também nesta formulação não é colocado nenhum fator capaz de explicar a peculiaridade das taxas de juro brasileiras.

Nas duas últimas seções, procuramos verificar se estudos empíricos para o caso do Brasil eventualmente encontrariam evidências de que o mecanismo acima discutido que, no regime de metas, relaciona a meta de inflação à taxa real de juros, conteria outros elementos particularmente importantes no funcionamento do regime que não a determinação das expectativas de inflação baseadas nas metas, e nas taxas nominais de juros respondendo diretamente às expectativas. Ou seja, buscava-se verificar se outros elementos que são normalmente incluídos nos modelos que analisam o regime de metas de inflação seriam especialmente relevantes no caso do Brasil, o que permitiria explicar sua singularidade no que se refere à manutenção de taxas de juros excepcionalmente elevadas; entretanto, não conseguimos identificar elementos com tais características.

O fato de que as expectativas de inflação sejam colocadas como elemento fundamental na determinação das taxas de juro na execução da política monetária, mostra que, pelo menos nos estudos analisados, não foi encontrada nenhuma evidência suficientemente forte que nos leve a crer que o regime de metas de inflação tenha necessariamente requerido que as taxas reais de juro tenham que ter sido tão elevadas como de fato o foram no Brasil desde sua implementação. Nos trabalhos acima discutidos, inclusive, encontram-se evidências que apontam na direção contrária ao que seria normalmente esperado de acordo com a teoria, com respeito à relação entre a taxa de juros e as expectativas de inflação. Assim, no trabalho de Cerisola e Gelos (2005), quando explicitamente incluídas no modelo que busca estimar os determinantes das expectativas, os coeficientes das taxas de juro não foram significativos. Resultados compatíveis são encontrados por de Mendonça (2005) que, estimando um modelo VAR, também não encontra significância das taxas de juros ao analisar a função de resposta ao impulso de uma variável construída de forma a medir a credibilidade do regime de metas. 
Minella et al (2003), por sua vez, procurando estimar uma a função de reação do Bacen dispondo de dados apenas até o fim de 2002, encontram um coeficiente positivo para as taxas de juros; ou seja, quanto maiores as taxas, maiores pareceriam ser as expectativas de inflação. Os autores justificam este fato pela ocorrência de choques de oferta apenas parcialmente acomodados pelo Bacen; assim, enquanto as expectativas aumentariam dado que a reação do Bacen não seria completa, as taxas de juros também se elevariam como parte da resposta parcial, caracterizando a relação positiva. De qualquer maneira, este tipo de constatação empírica não deixa de ser perturbador.

\section{Metas de inflação e credibilidade}

$\mathrm{O}$ argumento mais freqüentemente evocado no quadro do regime de metas de inflação para explicar e justificar a manutenção de elevadas taxas de juro se baseia na necessidade de buscar a credibilidade dos agentes em relação às metas fixadas e ao compromisso do próprio Bacen com a manutenção do regime; nesse sentido, a sustentação de uma política monetária rígida ("dura") por parte do Bacen sinalizaria aos agentes esse firme compromisso e contribuiria à construção da credibilidade do sistema, que normalmente consistiria num processo demorado. Essa necessidade se justificaria uma vez que a falta ou baixo nível de credibilidade dificultaria sobremaneira a execução e eventualmente levaria ao fracasso o regime de metas. Colocando o controle da inflação como objetivo principal, quando não único, da política monetária, e definindo o regime de metas de inflação como o mecanismo escolhido para concretizar essa tarefa, compreender-se-ia a defesa de uma política monetária rígida e a alta taxa de juros que ela implica, como forma de permitir que o regime alcançasse sucesso.

Entretanto, além de teoricamente sujeita à objeção relacionada ao problema da dominância fiscal anteriormente comentado (altas taxas de juros levariam a uma trajetória insustentável da dívida pública, conduzindo à elevação da percepção de risco e à tendência à desvalorização cambial, levando a pressões inflacionárias, o que constituiria um efeito contrário ao esperado; nessa situação, a elevação das taxas de juros não conduziria necessariamente a um ganho na credibilidade), a relação unívoca entre a manutenção da rigidez na política monetária e o aumento na credibilidade repousa sob evidências empíricas bastante frágeis. 
De fato, não há ainda estudos empíricos que verifiquem explicitamente essa relação, pelo menos para o caso brasileiro. As afirmações que ligam a política adotada ao suposto aumento da credibilidade se baseiam apenas em resultados previstos por modelos teóricos, sem suporte empírico, ou pela comprovação indireta da relação; assim, por exemplo, Minella et al (2003) chegam a essa conclusão a partir da constatação do papel alcançado pelas metas de inflação em ancorar as expectativas, o que somente teria sido possível se a política monetária houvesse efetivamente ganho credibilidade; e isto teria ocorrido graças ao "grande esforço" do Bacen, ao reagir fortemente - elevando significativamente as taxas de juros - a variações nas expectativas (como efetivamente vimos acima), além de buscar a transparência em sua comunicação. Este tipo de argumentação apoia-se, entretanto de forma decisiva em evidências indiretas que se sustentam em hipóteses não comprovadas, sendo assim altamente discutível.

Com isto, não se pretende aqui negar a existência de uma relação entre a maneira de conduzir a política monetária e a credibilidade que essa política possa dispor perante distintos grupos de agentes econômicos; aponta-se apenas para a ausência até o momento de evidências que permitam definir a estabilidade e relevância dessa relação.

Nesse sentido, resulta interessante citar o trabalho de Teles e Nemoto (2006), que procura estimar a evolução da credibilidade da política monetária entre 1980 e 2002, usando como parâmetro o trade-off entre inflação e desemprego, o qual, considerando que os agentes enfrentam custos ao ajustar seus preços, tenderia a elevar-se quando estes não esperam choques monetários, ou seja, quando não esperam que o Bacen se utilize do trade-off, caso no qual a política monetária de inflação baixa desfrutaria de alta credibilidade. Os resultados encontrados neste trabalho apontam que, enquanto o lançamento do Plano Real marca claramente um momento de inflexão em relação à credibilidade da política monetária, em que depois de seguidos anos de queda ela volta a aumentar e se mantém em níveis elevados a despeito dos vários choques ocorridos no período, a implementação do regime de metas de inflação não parece apontar uma elevação significativa da credibilidade da política. De fato, a capacidade da política monetária de influenciar as expectativas de inflação parece muito mais um resultado do ganho de credibilidade obtido com o Plano Real do que um ganho adicional que teria ocorrido com a implementação do regime de MI, que não parece ter sido significativo em relação ao nível já alcançado. A ausência de impacto significativo sobre a credibilidade da política que a adoção do regime de metas no Brasil - normalmente 
considerado como bem sucedido - parece mostrar, contrariando decisivamente o que seria teoricamente esperado, aponta para o cuidado com que se deve encarar este assunto.

Além das dúvidas acima colocadas em relação ao fato de que políticas monetárias restritivas necessariamente impactariam positivamente e de forma decisiva a credibilidade do regime de metas, é importante ressaltar que, mesmo aceitando que essa hipótese seja verdadeira, tanto a teoria que baseia o regime de metas (Bernanke et al, 1998) quanto os trabalhos empíricos aqui analisados, não são capazes de nos fornecer pistas acerca de quão restritivas essas políticas deveriam efetivamente ser e por quanto tempo elas deveriam ser sustentadas para que os resultados sobre a credibilidade se materializassem. Considerações relativas principalmente ao histórico mais ou menos recente da política monetária (Sicsú, 2002b) e à reputação adquirida ao longo do tempo, mas também à efetividade dos canais de transmissão da política (quanto mais eficientes estes canais fossem, menores teoricamente seriam as taxas de juro necessárias para impactar a inflação, o que se refletiria nas menores taxas necessárias para afetar as expectativas de inflação), são rotineiramente feitas, e podem fornecer indicativos indiretos nesse sentido. Entretanto, a própria noção necessariamente vaga da credibilidade assim como a dificuldade natural em aferi-la de forma direta torna os esforços que procuram relacioná-la a variáveis objetivas tais como a taxa de juros necessariamente espinhosos e normalmente infrutíferos.

Assim, com a inclusão aqui feita de considerações relativas à credibilidade, o que temos afinal é um novo elemento na fórmula que havia sido acima exposta, e que é ligeiramente aqui modificada: as taxas de juro seriam elevadas porque isso é necessário para que as metas de inflação possam ter credibilidade e sejam assim capazes de influenciar as expectativas de inflação, às quais por sua vez a política monetária reage. Nesta formulação, em que a taxa de juros é determinada como resultado de um processo redundante, torna-se explícito o que podemos chamar de caráter auto-referencial do regime de metas de inflação, em que a determinação dos valores assumidos pelas variáveis relevantes, no caso a taxa de juros, tem como referência apenas seus próprios valores defasados, caracterizando o que na literatura de séries temporais seria um processo de raiz unitária. De fato, neste sistema não há baliza externa alguma a limitar as taxas de juros: estas devem ser suficientemente elevadas e persistir o tempo que for necessário para que a credibilidade ganha pelas metas de inflação faça com que as expectativas em direção a essa meta convirjam. Esta conclusão é consistente com um dos resultados apontados no trabalho de Policano e Bueno (2006) discutido na seção 
anterior, que apontava justamente para o fato de que as expectativas de inflação, apesar de parecer ser capazes de explicar de forma satisfatória os movimentos nas taxas de juros, deixavam na estimação um intercepto elevado sem justificação, o que mostrava suas limitações em explicar os níveis daquelas taxas.

Com efeito, quais são as taxas suficientemente elevadas e quanto é o tempo necessário durante o qual elas devem ser mantidas é uma questão eminentemente empírica; portanto, ao não ser possível estabelecer nenhuma relação suficientemente clara e estável com os fundamentos econômicos, a princípio qualquer taxa de juros, sustentada por qualquer período de tempo, desde que seja considerada adequada pelos agentes cujas expectativas são aferidas pelo Bacen, e, portanto vistas como necessárias por ele, é capaz de perdurar indefinidamente; para que isso ocorra, não é necessário nenhum suporte além da manutenção das próprias expectativas dos agentes, estejam elas apoiadas em algum fundamento econômico ou não, caso no qual se caracterizariam como um fenômeno puramente convencional; é no sentido explicitado neste segundo caso que a formação das taxas de juros no regime de metas de inflação segue uma lógica auto-referencial.

Esta lógica não seria tampouco exclusiva do regime de metas de inflação - embora seja dele característica -, mas surge em todas as situações, como a verificada para o caso do Brasil, em que o Banco Central pauta (quase que) totalmente suas ações em função das expectativas dos mercados financeiros, definindo o caminho das taxas de juros de acordo ao que estes mercados esperam. Sem deixar de concordar que a reação dos mercados, pelo seu importante papel no mecanismo de transmissão da política monetária, deve ser certamente levada em consideração na definição desta política, é necessário apontar que, quando tal política acaba sempre sancionando suas expectativas, pode-se configurar um "perigoso fenômeno de

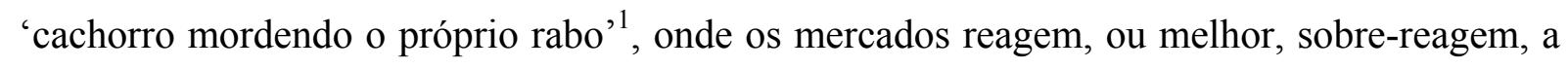
percepções sobre o que o Banco Central poderia fazer, e o Banco Central busca nos mercados a orientação sobre o que ele deveria fazer". (Blinder, 1998, pp.62). Considerando o caráter altamente sobre-reativo dos mercados financeiros e sua propensão a bolhas especulativas e caprichos (Shiller, 2000), sua tendência a crises financeiras (Kindleberger, 1996), além do comportamento extremamente focado em considerações de curto prazo, ao conduzir a política monetária procurando 'seguir os mercados', o Banco Central pode acabar obtendo resultados

\footnotetext{
1 “dog chasing its tail".
} 
de política medíocres, no que se refere à combinação de taxa de juros necessária para manter um determinado patamar de inflação.

O regime de metas de inflação seria particularmente sujeito a este tipo de crítica dada sua elevada ou total dependência, como vimos, em relação às expectativas de inflação. Sendo estas expectativas construídas num ambiente (os mercados financeiros) com as características particulares vistas acima, elas também estão sujeitas a sobre-reações, imobilismo, bolhas, pânicos, manias, e visão excessivamente curto-prazista. Assim, um regime de política monetária que não se apóia (como é normalmente o caso do sistema de metas em geral e o exemplo do Brasil em particular) de forma importante em outros elementos que não estas expectativas estará particularmente exposto ao impacto de fenômenos peculiares à lógica dos mercados financeiros, não especialmente adequados para a condução da política monetária.

De fato, a manutenção de taxas reais de juros excepcionalmente elevadas, alcançando patamares de inflação apenas razoáveis, por um prolongado período de tempo e sem outra justificativa aparente que não a própria dinâmica interna do regime, sugere que uma explicação mais adequada para o fenômeno seja buscada na lógica desses mercados.

\section{Considerações Finais}

Ao longo deste capítulo, procuramos identificar na condução da política monetária brasileira a eventual presença de elementos particulares que fornecessem os motivos que pudessem justificar a manutenção ao longo do tempo de taxas reais de juros no Brasil excepcionalmente elevadas. Particularmente, procurou-se verificar se as exigências específicas de uma política monetária cujo objetivo principal é manter a taxa de inflação sob controle poderiam implicar na necessidade de efetivamente sustentar as taxas de juro em níveis tão altos.

Após uma discussão detalhada dos conceitos que sustentam a definição da política monetária adotada no Brasil, procurou-se investigar, principalmente através da análise de trabalhos empíricos realizados sobre o assunto, os determinantes que conduzem à definição das taxas de juro por parte do Bacen, no âmbito na definição de política, procurando eventuais elementos singulares. Ao fazer-se isto, concluiu-se que a variação nestas taxas pode ser considerada como respondendo de forma quase exclusiva às flutuações das expectativas de inflação, e que 
tais expectativas se encotnram, na maior parte do tempo, ancoradas ao redor das metas de inflação definidas pelo Governo. Ou seja, a determinação das taxas de juros por parte do Bacen no regime de metas de inflação adotado no Brasil não sofreria a intervenção, pelo menos não direta ou decisiva, de considerações relativas a variáveis econômicas fundamentais.

De fato, esta lógica é própria a este tipo de regime, que fundamentalmente apenas estabelece o objetivo, uma determinada meta de inflação, recomenda clareza e transparência na divulgação e aplicação da política, de forma a fazer com que ela seja mais efetiva, e define o instrumento utilizado pelo Bacen para atingir essa meta, os movimentos na taxa de juros. Tal lógica não carrega, em si, nenhuma eventual relação estrutural entre as variáveis econômicas que pudesse sugerir condições de equilíbrio para as taxas reais de juro que não estivessem apenas apoiadas nas expectativas de inflação. Ou seja, a taxa real de juros de quilíbrio neste regime é simplesmente aquela que leva as expectativas de inflação a convergirem em direção à meta estabelecida, independentemente de quaisquer considerações relativas às variáveis reais. Considerando-se a perspectiva teórica, comprovada empiricamente para o caso do Brasil, de que as expectativas de inflação são definidas com base na meta, conclui-se pelo caráter autoreferencial da determinação das taxas de juro no modelo. É neste sentido que a ocorrência de quaisquer taxas de juros, desde que respondam à condição acima, seria possível.

A teoria sobre a qual se apóia esta formulação não vê normalmente esta possibilidade como realmente relevante uma vez que considera de forma implícita que, verificando-se a hipótese das expectativas racionais, as taxas reais de juro necessárias para fazer com que as expectativas de inflação convirjam em direção e se mantenham em torno de suas metas caminhariam naturalmente em direção à taxa natural de juros, que seria a taxa de equilíbrio na economia e forneceria portanto o parâmetro a partir do qual poderia explicar-se a taxa real de juros de longo prazo, negando assim a possibilidade que uma multiplicidade de taxas possam exercer este papel.

Assim, em um sistema de metas, idealmente (ou mesmo no caso do Brasil, em que as expectativas são, como vimos, o elemento principal na determinação das taxas de juros por parte do Bacen) a relação entre as taxas reais de juro e as variáveis reais da economia não ocorre de forma direta mas é estabelecida por intermédio das expectativas, apoiando-se decisivamente na hipótese de que estas seriam normalmente capazes de refletir 
adequadamente o estado dessas variáveis. Se isto se verificasse, o próprio movimento das expectativas levaria as taxas reais de juro a se aproximar da taxa natural.

Evidentemente, críticas importantes podem ser colocadas a uma formulação que depende em grau tão elevado da racionalidade das expectativas - rejeitadas, por exemplo, no caso do Brasil no que se refere à sua ação conjunta com a hipótese das expectativas na previsão da estrutura a termo das taxas de juro, como mostrado por Tabak e Andrade (2001) - , e da separação das variações que nestas se verificam em relação aos movimentos acima discutidos, normalmente associados ao comportamento dos mercados financeiros. Tais hipóteses são de fato fundamentais pois, se as expectativas não apresentassem o padrão previsto e estivessem sujeitas a fenômenos como os verificados nesses mercados, elas não seriam capazes de conduzir as taxas reais de juro em um caminho definido em direção a qualquer que fosse a taxa natural (taxa que, de resto, teve seu significado empírico fortemente questionado no capítulo anterior), deixando que sua determinação ocorresse como parte de um processo de caráter fundamentalmente auto-referencial.

Como conclusão deste capítulo, podemos afirmar que a política monetária seguida no Brasil, e o regime de metas em particular, quando funcionando de acordo ao teoricamente previsto, não introduz nenhum elemento novo, originado em necessidades intrínsecas à sua dinâmica - que como vimos, se encerra em si mesma sem a inclusão de variáveis econômicas fundamentais - , que possa contribuir decisivamente na explicação das taxas reais de juro particularmente elevadas vigentes no Brasil. 


\section{CONCLUSÃO}

Neste trabalho procurei contribuir ao debate que trata da manutenção ao longo de vários anos, e sem a perspectiva de uma mudança significativa no futuro próximo, de taxas reais de juro excepcionalmente elevadas no Brasil. Esta questão é hoje certamente o problema econômico mais freqüentemente debatido tanto dentro do ambiente acadêmico quanto entre amplos setores da sociedade, através da imprensa geral e especializada, o que se justifica considerando suas implicações extremamente importantes sobre a economia do país, especialmente através de seus efeitos diretos sobre as decisões de investimento e assim, portanto, sobre o crescimento econômico, e por seus impactos consideráveis sobre a estrutura da distribuição da renda nacional.

Paradoxalmente, apesar da difusão do debate em torno do assunto e de sua grande relevância, até o momento poucos trabalhos acadêmicos têm procurado abordar de forma sistemática a questão, através da discussão e da verificação empírica da validade das diferentes explicações que têm sido sugeridas, e encarando deliberadamente a situação em seu caráter excepcional, que requer uma explicação específica. De fato, no debate acadêmico tem prevalecido de modo geral uma visão em boa medida conformista, que tende a aceitar de forma pouco crítica a validade e relevância de algumas teorias que justificariam a situação corrente sem a necessária comprovação empírica. Neste contexto, a maior parte do debate giraria em torno da análise de alguns aspectos do funcionamento da política monetária no bojo da qual as taxas de juro seriam definidas, mas sem questionar aqueles pressupostos, nem assumir a excepcionalidade da situação.

Como forma de preencher este certo vazio percebido no debate, procurei neste trabalho, numa primeira abordagem, discutir, a partir da análise de trabalhos teóricos e empíricos recentes tratando em sua maioria sobre o caso particular do Brasil, as principais teorias sobre o assunto que têm sido sugeridas no campo da ortodoxia, o qual tem norteado a formulação da política monetária no país, de forma a verificar se os resultados que tais teorias têm alcançado no que se refere à sua capacidade de explicar a situação brasileira são efetivamente satisfatórios. As teorias analisadas procuram sempre explicar a excepcionalidade das taxas reais de juro vigentes no Brasil a partir de uma taxa natural de juros que também seria particularmente elevada. Assim, procurou-se justificar esta eventual peculiaridade do caso brasileiro verificando, por um lado, a suposta posição singular do Brasil em distintas aproximações 
diretas da taxa natural; e por outro, dos alegados níveis também particularmente elevados de fatores que afetariam a taxa natural, representados por variáveis relacionadas à incerteza jurisdicional, à inércia inflacionária, aos gastos e dívida pública, e aos níveis de risco. Após examinar de forma crítica as teorias selecionadas e discorrer sobre os resultados que cada uma delas tem apresentado, a conclusão global aponta basicamente para a insuficiência, teórica mas especialmente empírica, destas teorias em dar conta da excepcionalidade do caso brasileiro em relação a esta questão. Ou seja, os níveis das taxas reais de juro vigentes no Brasil não encontrariam até o momento explicação satisfatória nas teorias mais geralmente aceitas pela ortodoxia econômica.

A segunda abordagem utilizada neste trabalho procurou verificar diretamente se as necessidades associadas à consecução dos objetivos - fundamentalmente o controle da inflação - definidos para a política monetária implementada no país, da qual a taxa nominal de juros (que tem mantido uma relação direta com a taxa real) é o instrumento principal, considerando as características particulares da política adotada, poderiam justificar a situação tão particular assumida por estas taxas. Aqui também, após proceder a uma análise teórica mas também de trabalhos empíricos sobre os fundamentos e mecanismos envolvidos na definição da política monetária atualmente adotada pelo Bacen no Brasil, não se encontraram nos requisitos dessa política elementos que inequivocamente levariam a tal situação. Notouse, como singularidade dessa política, o caráter auto-referencial assumido pela determinação das taxas de juros; ou seja, não somente efetivamente não se achou na política seguida a justificativa para as especialmente elevadas taxas reais de juro em vigor no país, mas também não se identificaram nessa política mecanismos capazes de explicar satisfatoriamente quaisquer que fossem os níveis dessas taxas.

Assim, nenhuma das duas abordagens utilizadas foi capaz de fornecer uma contribuição satisfatória à identificação dos motivos que explicariam as excepcionalmente elevadas taxas reais de juro vigentes no Brasil. Estas taxas continuariam, portanto - pelo menos dentro do paradigma ortodoxo que sustenta as teorias discutidas no primeiro capítulo e que guia a definição da política monetária no Brasil -, sem justificativa adequada.

Diante da insuficiência das explicações ortodoxas, e como indicação de um possível caminho alternativo a ser eventualmente seguido na busca de soluções para esta importante questão, que como vimos ainda está em aberto, concluímos este trabalho introduzindo a abordagem da 
análise econômica das convenções (Orléan, 1994), a qual explicaria as elevadas taxas reais de juro vigentes no Brasil como resultando de convenções específicas criadas seguindo uma lógica fortemente auto-referencial, convenções que pautam os comportamentos dos agentes.

Este caminho alternativo de ver a questão considera a definição das taxas de juro como sendo um fenômeno eminentemente convencional, “[...] pois o seu valor observado depende sobremaneira do valor futuro que se lhe prevê. Qualquer taxa de juros aceita com suficiente convicção como provavelmente duradoura será duradoura; [...]" (Keynes, 1983, pp.144) Isto significa que a taxa de juros em vigor não estaria nessa posição por tratar-se ela de algum valor de equilíbrio compatível com os valores assumidos por outras variáveis na economia, ou seja, não por ser ela uma taxa de equilíbrio de acordo com os "fundamentos" econômicos, mas por ser a taxa definida a partir de uma convenção em que os participantes do mercado a elegeram como a taxa válida. Essa taxa "[...] pode flutuar durante décadas ao redor de um nível cronicamente elevado demais para permitir o pleno emprego [...]”. (ibid.pp.144)

O sentido de tal afirmação encontra-se, seguindo Orléan (1999), num contexto em que os agentes atuam de acordo à lógica que ele denomina de auto-referencial, a qual fundamenta o comportamento dos agentes que não procuram identificar o valor intrinsecamente "correto" de uma variável (racionalidade fundamentalista), nem tampouco buscam prever o valor que outros agentes possam considerar como sendo o correto (racionalidade estratégica), mas o valor que todos os agentes consideram como sendo a opinião majoritária do grupo; ou seja, não se procura opiniões próprias nem de outros agentes baseadas em crenças pessoais apoiadas em fundamentos, mas as opiniões do conjunto dos agentes que resulta da busca empreendida por cada um deles para encontrar aquela opinião majoritária. Neste contexto, não existe portanto a priori nenhuma determinação inequívoca do valor que uma variável deva assumir. Tal valor será resultado do próprio processo de interação entre os agentes, sendo que as referências a partir das quais estes agentes determinam seu comportamento são produzidas de forma interna ao processo, denotando assim seu caráter auto-referencial, de forma semelhante à que foi apontada no capítulo anterior em relação à definição da taxa de juros no regime de metas de inflação.

Um resultado possível para esse tipo de processo ocorre quando, como vimos acima, cada agente, ao invés de analisar os dados objetivos e a partir deles determinar suas ações, procura descobrir a opinião majoritária entre os agentes acerca da opinião majoritária entre os agentes 
e assim por diante. A auto-referencialidade, neste caso, pode ser interpretada como "[...] um mecanismo prodigioso de amplificação dos rumores, o que confirma plenamente a observação dos mercados financeiros." (Orléan, 1999, pp.74) Entretanto, a aparente total indeterminação daqui resultante não é o único resultado possível. De fato, naqueles que são chamados de jogos de pura coordenação (Schelling, 1960), os agentes obtêm os maiores pay-offs quando são capazes de coordenar suas escolhas. Para fazer isso, eles procuram usar capacidades cognitivas mais extensas que nas abordagens tradicionais, de forma a encontrar uma maneira específica de conceber o problema do jogo, uma particularidade que faça aparecer aos olhos de todos e sem ambigüidade um ponto único de coordenação, desta forma aumentando a probabilidade de que um resultado assim "coordenado" emirja. Quando este tipo de interação é repetida seguidamente, o comportamento natural por parte de cada agente de imitação das escolhas que se mostraram majoritárias no momento anterior conduz a que, após algumas repetições, as escolhas individuais se aproximem dessa escolha majoritária, que não tem necessariamente que ser intrinsecamente a mais adequada, mas que assim resulta, no contexto deste jogo, apenas pelo fato de ser a escolhida por todos. Uma vez que a unanimidade é atingida, a opinião do grupo se estabiliza e alcança um "equilíbrio", já que a imitação não mais modifica a situação, apenas reproduzindo a unanimidade anterior. Nessa situação, a escolha unânime que se torna a previsão natural para o futuro se transforma numa convenção.

O processo que conduz à criação desta convenção pode desembocar numa variedade de resultados, dependendo da própria dinâmica interna do processo e de uma variedade de fatores menores, sem necessariamente estar associados com nenhum fundamento econômico. Entretanto, o resultado alcançado deve efetivamente aparecer como legítimo aos olhos de todos os participantes, o que faz com que a convenção deva estar assentada sobre uma base convincente; ou seja, poderíamos dizer que uma verossimilhança mínima em relação aos fundamentos seria exigida, embora tal nível mínimo possa ser interpretado de forma bastante ampla. Uma vez estabelecida a convenção, ao tomar as decisões, os agentes não precisam mais se esforçar por descobrir as escolhas dos demais agentes de forma a com eles se coordenar, bastando para isso se voltar para a convenção. Assim, cada agente não mais se preocupa com os demais, mas apenas com essa convenção. Enquanto ela não for decisivamente desafiada, funciona como a melhor antecipação do futuro. Dessa forma, a convenção acaba adquirindo um status muito similar ao atribuído aos fundamentos numa lógica da ação fundamentalista como a tradicionalmente (mas não exclusivamente) considerada pela ortodoxia, e seu caráter convencional é inclusive esquecido. Assim, cada 
agente vê no modelo convencional de interpretação o verdadeiro modelo da realidade sem colocar em causa sua validade. Assim, "racionalidade fundamentalista e racionalidade autoreferencial se tornam então indistinguíveis.” (op cit, pp.87)

Esta construção pode ser transplantada de forma proveitosa para a análise do problema que nos preocupa neste trabalho, relacionado às taxas reais de juro particularmente elevadas vigentes no Brasil. De fato, como anteriormente afirmado, não encontramos, ao examinar a política monetária seguida no Brasil, nenhum elemento que estabelecesse o nível "correto" a ser assumido pelas taxas de juro de acordo com algum tipo de fundamento econômico; o modelo apenas estabelece que estas taxas deveriam ser aquelas que fariam com que as expectativas de inflação convergissem em direção à meta fixada, e que, conforme o sistema fosse mantido, as taxas necessárias para alcançar este objetivo convergiriam para a taxa natural de juros. Sendo que tal convergência se daria somente no longo prazo não existiria, portanto, nenhum limite restringindo a priori os patamares das taxas de juro no curto prazo, sendo estas, portanto, determinadas de forma auto-referencial no modelo, podendo assim ser fixadas numa multiplicidade de níveis diferentes.

A partir destas considerações, a definição das taxas de juro pode ocorrer dentro do que podemos identificar como sendo um jogo de coordenação pura como aquele acima discutido, em que os participantes no mercado de títulos públicos obteriam os maiores pay-offs ao se coordenar para exigir em conjunto a definição por parte do Banco Central das taxas de juro mais elevadas possíveis. No caso de que tal coordenação não fosse alcançada, lançar-se-ia um processo de concorrência ao curso do qual as taxas de juros resultantes teriam grande probabilidade de resultar menores do que as que são atualmente verificadas. Somente quando todos os agentes (ou os relevantes) exigissem uma mesma taxa, é que esta poderia funcionar como ponto focal, e dar possivelmente origem a uma convenção, caracterizada por manter-se válida até ser desafiada de forma decisiva, o que não ocorreria normalmente enquanto todos os agentes tenham motivos para acreditar que as previsões nela baseadas se verificarão.

A seguida interação entre os participantes do "jogo" dentro do qual as taxas de juro são definidas, incluindo o próprio Bacen como agente mais importante, levou à emergência de várias convenções as quais, como vimos, tendem a estabilizar os comportamentos e tornar os resultados mais previsíveis. Estas convenções se referem tanto à definição da taxa de juros adequada em cada momento, quanto à concepção acerca do funcionamento da economia sobre 
a qual a definição das taxas para todos os períodos se baseia. Como exemplos deste tipo de convenção que teria emergido, os dois provavelmente mais importantes são os seguintes:

- O Brasil se caracterizaria por uma taxa natural de juros particularmente elevada, em torno de $10 \%$, e que, portanto, taxas reais compatíveis com essa magnitude não seriam de forma alguma excepcionais, não levando a nenhum tipo de preocupação específica.

- O produto potencial da economia cresceria a uma taxa próxima a 3,5\%; portanto, se o produto real crescesse a taxas mais elevadas do que esse valor caracterizar-se-ia uma situação de pressão sobre a demanda agregada que conduziria a pressões inflacionárias, exigindo a elevação das taxas de juro.

Podemos concluir pelo caráter convencional de tais afirmações considerando que, embora teoricamente possíveis, as evidências empíricas que as sustentam são necessariamente frágeis, se lembrarmos das dificuldades apontadas no primeiro capítulo em relação à estimação da taxa natural de juros, e os graves problemas envolvidos na estimação do produto potencial. Apesar da falta de evidências assinalada, ambas as estimações têm sido continuamente utilizadas como verdades incontestes, em grande número de trabalhos acadêmicos e argumentos publicamente colocados em defesa da política monetária aplicada pelo Bacen. Seu possível caráter convencional é efetivamente ignorado, assumindo-se estas afirmações como representando fielmente os fundamentos econômicos.

A existência de tais convenções partilhadas tanto pelos participantes do mercado de títulos públicos quanto pelo próprio Bacen, convenções que tendem naturalmente a estabilizar os comportamentos e as previsões dos agentes e assim a realidade objetiva sem o compromisso com o comportamento de variáveis fundamentais, poderia se colocar como um elemento particularmente adequado na explicação da permanência durante seguidos anos de taxas reais de juro excepcionalmente elevadas no Brasil.

Mesmo uma visão superficial da economia das convenções como a que foi aqui apresentada, dada a facilidade com que a explicação empreendida a partir das convenções parece adequarse à problemática aqui introduzida, deve despertar o interesse pela utilização desta abordagem em futuros trabalhos estudando esta questão. 


\section{REFERÊNCIAS}

ALVES, S.A.L.; AEROSA, W.D. Targets and Inflation Dynamics. Working Paper Series $\mathrm{n}^{\circ} 100$, Banco Central do Brasil. Brasilia, outubro 2005.

AMATO, J. The role of the Natural Rate of Interest in Monetary Policy. CESifo Economic Studies, vol.51, p.729-755, abril 2005.

ARESTIS, P.; de PAULA, L.F.; FERRARI FILHO, F. Inflation Targeting in Emerging Countries: the Case of Brazil. XXIV Encontro Nacional de Economia. Salvador, 2006.

ARIDA, P., BACHA, E.L.,LARA-RESENDE, A. Credit, Interest, and Jurisdictional Uncertainty: Conjectures on the case of Brazil. Instituto de Estudos de Política Econômica, Casa das Garças, Rio de Janeiro, 2004.

BALL, L.; SHERIDAN, N. Does Inflation Targeting Matter? NBER Working Papers $\mathrm{n}^{\circ}$ 9577, National Bureau of Economic Research, 2003.

BACEN. Carta Aberta ao Ministro da Fazenda. Banco Central do Brasil, Brasília, fevereiro 2004.

BACEN. A determinação da taxa de juros no Brasil. Apresentação à Comissão de Assuntos Econômicos do Senado, Banco Central do Brasil, Brasília, junho 2006.

BACEN. Séries temporais. Economia e finanças, Banco Central do Brasil, disponível em http://www.bcb.gov.br.

BARBOSA, F. H. Inflação: inércia e déficit público. Ensaios Econômicos EPGE, nº533. Rio de Janeiro, 2004a.

A inércia da taxa de juros na política monetária. Ensaios Econômicos EPGE, $\overline{\mathrm{n}^{0} 534 .}$ Rio de Janeiro, 2004b.

The Contagion Effect of Public Debt on Monetary Policy: The Brazilian Experience. Revista de Economia Política, v.26, n², p.231-238, abr-jun 2006.

BARCELLOS, P.C.F.; PORTUGAL, M.S. The Natural Rate of Interest in Brazil between 1999 and 2005. XXIV Encontro Nacional de Economia. Salvador, 2006.

BERNANKE, B.; MISHKIN, F.S. Inflation Targeting: a new framework for monetary policy? NBER Working Papers $\mathrm{n}^{\mathrm{0}} 5893$, National Bureau of Economic Research, janeiro 1997.

BERNANKE, B.; LAUBACH, T.; MISHKIN, F.S.; POSEN, A.S. Inflation Targeting: Lessons from the International Experience. Princeton University Press, 1999.

BLANCHARD, O. Fiscal Dominance and Inflation Targeting: lessons from Brazil. NBER Working Papers n⿳亠丷10389, National Bureau of Economic Research, março 2004.

BLINDER, A. Central Banking in Theory and Practice. Cambridge, MIT Press, 1998.

BLINDER, A.; GOODHART, P.H.; LIPTON, D.; WYPLOSZ, C. How do Central Banks Talk? Geneva Report on the World Economy 3, International Center for Monetary and Banking Studies, 2001. 
BOGDANSKY, J.; TOMBINI, A.A.; WERLANG, S.R.da C. Implementing Inflation Tatergeting in Brazil. Working Paper Series $\mathrm{n}^{0} 1$, Banco Central do Brasil. Brasilia, julho 2000 .

BOGDANSKY, J.; de FREITAS, P.S.; GOLDFAJN, I; TOMBINI, A.A.. Inflation Tatergeting in Brazil: Shocks, Backward-Looking Prices, and IMF Conditionality. Working Paper Series n 24, Banco Central do Brasil. Brasilia, agosto 2001.

BRITO, R.D.; DUARTE, A.J.M.A.; GUILLÉN, O.T.C. Reação Exagerada dos Diferenciais de rendimentos e movimentos das taxas de juros brasileiras. Financelab Working Paper 09, IBMEC São Paulo, janeiro 2004.

BUENO, R.D.L.S. The Taylor Rule under Inquiry: Hidden states. Seminários Bacen-USP de Economia Monetária e Bancária, Universidade de São Paulo, IPE, $2^{\circ}$ semestre 2005.

CANUTO, O; SANTOS, P.F.P. Risco-Sobreano e Prêmios de Risco em Economias Emergentes. Temas de Economia Internacional 01, Ministério da Fazenda, Secretaria de Assuntos Internacionais, Brasília, outubro 2003.

CARNEIRO, D.D.; WU, T.Y.H. Dominância fiscal e desgaste do instrumento único de política monetária no Brasil. Instituto de Estudos de Política Econômica, Casa das Garças, Rio de Janeiro, Texto para Discussão $\mathrm{n}^{0} 7$, maio 2005.

CERISOLA, M.; GELOS, R.G. What Drives Inflation Expectations in Brazil? An Empirical Analysis. IMF Working Paper 05/109, International Monetary Fund, junho 2005.

CLARIDA, R., GALÍ, J., GERTLER, M. The Science of Monetary Policy: A New Keynesian Perspective. Journal of Economic Literature, Vol.37, nº , pp 1661-1707, dezembro 1999.

. Monetary Policy Rules and Macroeconomic Stability: Evidence and some theory. Quarterly Journal of Economics, vol.115, nº 1, pp.147-80, 2000.

COPOM/BACEN. Atas de Reunião. Vários números 1998-2007. Banco Central do Brasil.

DE FREITAS, P.S.; MUINHOS, M.K. A Simple Model for Inflation Targeting in Brazil. Working Paper Series n ${ }^{\circ} 18$, Banco Central do Brasil. Brasilia, abril 2001.

DE MIRANDA, P.C.; MUINHOS, M.K. A taxa de juros de equilíbrio: uma Abordagem Múltipla. Working Paper Series nº6, Banco Central do Brasil. Brasilia, fevereiro 2003.

DORNBUSCH, R.; FISCHER, S. Macroeconomia. 5.ed. São Paulo: Makron Books, 1991.

EICHENGREEN, B. Can Emerging Markets Float? Should They Inflation Target? Working Paper Series n ${ }^{0} 36$, Banco Central do Brasil. Brasilia, fevereiro 2002.

FARHI, M. A ineficácia da política monetária. UNICAMP, Instituto de Economia, Política Econômica em Foco n5, nov/2004-abr/2005.

FAVERO, C.A.; GIAVAZZI, F. Why are Brazil's Interest Rates so High? IGIER, Università Bocconi, Milão, 2002.

Inflation Targeting and Debt: Lessons from Brazil. NBER Working Papers $\mathrm{n}^{\circ} 10390$, National Bureau of Economic Research, março 2004. 
FRAGA, A. Fiscal Dominance and Inflation Targeting: Lessons from Brazil.Inflation Targeting, Debt and the Brazilian Experience, 1999 to 2003. in Giavazzi, F. et al (orgs), Massachusetss, MIT Pres, 2005.

Fundo Monetário Internacional - FMI. International Financial Statistics - IFS. Disponível em http://www.imf.org.

GARCIA, M. Brazil in the 21st Century: How to Escape the High Real Interest Trap? PUCRio, Texto para Discussão, $\mathrm{n}^{\circ} 466$, Rio de Janeiro, 2002.

GARCIA, M. Juros altos e arriscados. Valor Econômico, 9 de julho 2003.

GONÇALVES, C.E.S. Inflation Targeting in Emerging Economies: What do the Data Say? Programa de Seminários Acadêmicos, São Paulo, IPE-USP, junho 2005.

GONÇALVES, F.M.; HOLLAND, M.; SPACOV, A.D. Can Jurisdictional Uncertainty and Capital Controls Explain the High Level Real Interest Rates in Brazil? Evidence from Panel Data. XXIII Encontro Nacional de Economia. Natal, 2005.

HETZEL, R.L. The Taylor Rule: Is It a Useful Guide to Understanding Monetary Policy? Federal Reserve Bank of Richmond, Economic Quarterly, vol.86/2, primavera 2000.

HOLLAND, M. Monetary and Exchange Rate Policy in Brazil after Inflation Targeting. XXIII Encontro Nacional de Economia. Natal, 2005.

IBGE. Sistema IBGE de Recuperação Automática - SIDRA. Instituto Brasileiro de Geografia e Estatística, disponível em http://www.ibge.gov.br.

ISARD, P. Uncovered Interest Parity. IMF Working Paper 06/96, International Monetary Fund, abril 2006.

KEYNES, J.K. Teoria Geral do Emprego, do Juro e do Dinheiro. São Paulo, Abril Cultural, 1983.

KINDLEBERGER, C. Manias, pânico e crashes: um histórico das crises financeiras. Rio de Janeiro: Nova Fronteira, 2000.

LAMEIRAS, M.A.P.; GIAMBIAGI, F. Um caso de inércia inflacionária: o que está acontecendo com os preços dos bens e serviços não comercializáveis? Nota Técnica IPEA, Rio de Janeiro, 2005.

LAUBACH, T.; WILLIAMS, J.C. Measuring the Natural Rate of Interest. The Review of Economics and Statistics, MIT Press, vol.85(4), p.1063-1070, novembro 2003.

LE HERON, E. A New Consensus on Monetary Policy? Revista de Economia Política, v.23, $\mathrm{n}^{\mathrm{o}} 4$, p.3-27, out-dez 2003.

LEICHSENRING, D. R. Endogeneidade e Mecanismos de Transmissão entre a Taxa de Juros Doméstica e o Risco Soberano: uma Revisita aos Determinantes do Risco-Brasil. Dissertação de Mestrado. Universidade de São Paulo, FEA, São Paulo, 2004.

LOUREIRO, A.S.; BARBOSA, F.H. Public Debt and Risk Premium of Public Securities in Brazil. Notas Técnicas, Banco Central do Brasil, novembro 2003.

MAIA, A.L.S., CRIBARI-NETO, F. Dinâmica inflacionária brasileira: resultados de autoregressão quantílica. Revista Brasileira de Economia, v.60, n² , p.153-165, abr-jun 2006. 
McCALLUM, B.T. Monetary Policy Analysis. NBER Reporter, primavera 2003.

MENDONÇA, H.F. Mensurando a credibilidade do regime de metas inflacionárias no Brasil. Revista de Economia Política, v.24, nº3, p.344-350, jul-set 2004.

Metas para inflação e variáveis macroeconômicas: uma Avaliação Empírica. Anpec, XXIII Encontro Nacional de Economia. Natal, 2005.

Transparência, condução da política monetária e metas para inflação. Nova Economia, Belo Horizonte, vol.16, n ${ }^{0} 1$, p.175-198, jan-abr 2006.

MINELLA, A. Monetary Policy and Inflation in Brazil (1975-2000): a VAR Estimation. Working Paper Series n³3, Banco Central do Brasil. Brasilia, novembro 2001.

MINELLA, A.; de FREITAS, P.S.; GOLDFAJN, I; MUINHOS, M.K. Inflation Targeting in Brazil: Constructing Credibility under Exchange Rate Volatility. Working Paper Series $n^{\circ} 77$, Banco Central do Brasil. Brasilia, julho 2003.

MUINHOS, M.K.; de FREITAS, P.S.; ARAUJO, F. Uncovered Interest Parity with Fundamentals: A Brazilian Exchange Rate Forecast Model. Working Paper Series n ${ }^{0} 19$, Banco Central do Brasil. Brasilia, maio 2001.

MUINHOS, M.K.; NAKANE, M.I. Comparing Equilibrium Real Interest Rates: Different Approaches to Measure Brazilian Rates. Working Paper Series $\mathrm{n}^{\circ} 101$, Banco Central do Brasil. Brasilia, março 2006.

NAKANO, Y. O Regime Monetário, a Dívida Pública e a Alta Taxa de Juros. Conjuntura Econômica, vol. 59, $\mathrm{n}^{\mathrm{o}}$ 11, p.: 10-12, novembro, 2005.

NISHIJIMA, S. Government Debt and InflationTargeting in Brazil. RIEB Discussion Paper Series $\mathrm{n}^{0} 167$, Research Institute for Economics and Business Administration, Kobe Universitty, janeiro 2005.

OREIRO, J.L.; DE PAULA, L.F.; DA SILVA, G.J.C. Por uma moeda parcialmente conversível: uma crítica a Arida e Bacha. Revista de Economia Política, v.24, nº 2, p.223-237, abr-jun 2004.

ORLÉAN, A. (org) Analyse économique des conventions. Paris, Presse Universitaires de France, 1994.

Le pouvoir de la finance. Paris, Editions Odile Jacob, 1999

PIZA, E.C.; DIAS, J. Novo consenso macroeconômico e política monetária no Brasil: uma Avaliação Empírica. Anpec, XXIV Encontro Nacional de Economia. Salvador, 2006.

POLICANO, R.M.; BUENO, R.D.L.S. A Sensibilidade da política monetária no Brasil: 1995-2005. Anpec, XXIV Encontro Nacional de Economia. Salvador, 2006.

QUARESMA, J.C.; GNAN, E.; RITZBERGER-GRUNWALD, D. The Natural Rate of Interest - Concepts and Appraisal for the Euro Area. Oesterreichische Nationalbank, Monetary Policy \& The Economy, Q4/05, dezembro 2005.

SANT'ANNA, J.P.da F.P. Estudo da Flutuabilidade do Câmbio Brasileiro. Dissertação de Mestrado. PUC-Rio, Rio de Janeiro, 2003.

SCHELLING, T.C. The strategy of conflict. Oxford University Press, 1960. 
SHILLER, R. Exuberância Irracional. São Paulo: Makron Books, 2000.

SICSÚ, J. Teoria e evidências do regime de metas inflacionárias. Revista de Economia Política, v.22, n⿳1, p.23-33, jan-mar 2002a.

- Expectativas inflacionárias no regime de metas de inflação: uma análise preliminar do caso brasileiro. Economia Aplicada, vol. 6, n 4, p.: 703-11, 2002b.

SOARES, J.S.S.; BARBOSA, F.H. Regra de Taylor no Brasil: 1999-2005. Anpec, XXIV Encontro Nacional de Economia. Salvador, 2006.

SOUZA JUNIOR., J.R.C. Produto Potencial: conceitos, métodos de estimação e aplicação à economia brasileira. Texto para Discussão IPEA, nº 1130, Rio de Janeiro, 2005.

STANDARD AND POOR'S. Sovereign Credit Ratings: A Primer. Nova York: Standard and Poor's, dezembro 1998.

TABAK,B.M.; ANDRADE, S.C. Testing the Expectations Hypothesis in the Brazilian Term Structure of Interest Rates. Working Paper Series n ${ }^{\circ} 30$, Banco Central do Brasil. Brasilia, novembro 2000.

TAYLOR, J. Discretion versus Policy Rules in Practice. Carnegie-Rochester Conference Series on Public Policy, 1993.

. Five Things We Know for Sure. Hoover Digest. 1998 n³3.

TELES, V.K., NEMOTO, J. O regime de metas de inflação do Brasil é Crível? Revista Brasileira de Economia, v.59, n⿳⺈, p.483-505, jul-set 2005.

TELES, V.K.; BRUNDO, M. Medidas de política monetária e a função de reação do Banco Central do Brasil. Anpec, XXIV Encontro Nacional de Economia. Salvador, 2006.

TROSTER, R.L. Política Monetária. Boletim de Informações da FIPE, Fundação Instituto de Pesquisas Econômicas, fevereiro 2007.

WICKSELL, K. Interest and Prices. Londres, Macmillan, 1936.

WOODFORD, M. Interest and Prices. Princeton University Press, 2003.

YUKI, E.T. Uma análise em painel dos determinantes do risco país com um modelo de reputação internacional. Dissertação de Mestrado. Universidade de São Paulo, FEA, São Paulo, 2004.

ZOLI, E. How does fiscal policy affect monetary policy in emerging markets countries? BIS Working Papers $\mathrm{n}^{\circ} 174$, Bank for International Settlements, abril 2005. 